\title{
Pilbara stygofauna: deep groundwater of an arid landscape contains globally significant radiation of biodiversity
}

\author{
S.A. Halse ${ }^{1,2}$, M.D. Scanlon ${ }^{1,2}$, J.S. Cocking ${ }^{1,2}$, H.J. Barron ${ }^{1,3}$, J.B. Richardson ${ }^{2,5}$ and S.M. Eberhard ${ }^{1,4}$
}

\author{
${ }^{1}$ Department of Parks and Wildlife, PO Box 51, Wanneroo, Western Australia 6946, Australia; \\ email: stuart.halse@bennelongia.com.au
}

${ }^{2}$ Bennelongia Environmental Consultants, PO Box 384, Wembley, Western Australia 6913, Australia.

${ }^{3}$ CITIC Pacific Mining Management Pty Ltd, PO Box 2732, Perth, Western Australia 6000, Australia.

${ }^{4}$ Subterranean Ecology Pty Ltd, 8/37 Cedric St, Stirling, Western Australia 6021, Australia.

${ }^{5}$ VMC Consulting/Electronic Arts Canada, Burnaby, British Columbia V5G 4X1, Canada.

\begin{abstract}
The Pilbara region was surveyed for stygofauna between 2002 and 2005 with the aims of setting nature conservation priorities in relation to stygofauna, improving the understanding of factors affecting invertebrate stygofauna distribution and sampling yields, and providing a framework for assessing stygofauna species and community significance in the environmental impact assessment process.
\end{abstract}

Approximately 350 species of stygofauna were collected during the survey and extrapolation suggests that 500-550 actually occur in the Pilbara, although taxonomic resolution among some groups of stygofauna is poor and species richness is likely to have been substantially underestimated. More than 50 species were found in a single bore. Even though species richness was underestimated, it is clear that the Pilbara is a globally important region for stygofauna, supporting species densities greater than anywhere other than the Dinaric karst of Europe. This is in part because of a remarkable radiation of candonid ostracods in the Pilbara. Ostracods are the dominant stygofaunal group in terms of both species richness and animal abundance. Together, ostracods, copepods, amphipods and oligochates comprised $77 \%$ of species and $96 \%$ of animals collected.

Stygofauna were found in $72 \%$ of samples collected and $81 \%$ of wells sampled. The average sample (including those without stygofauna) contained $3.2 \pm 0.1$ species. A feature of the Pilbara is that stygofauna occur across most of the landscape, often where the depth to groundwater is considerable, although yields were low where depth to groundwater was $>30 \mathrm{~m}$. Another feature is high endemicity: on the basis of current taxonomy $98 \%$ of the stygobites and $83 \%$ of the other groundwater species occur only within the region. Few factors affecting stygofauna occurrence could be identified, however. Numbers of specimens and species collected were positively related to well diameter and negatively related to depth to groundwater. Numbers of species declined in inland sub-regions, although variability within sub-regions was high.

While a range of freshwater chemistries occurred, $79 \%$ of water samples were weakly saline and $\mathrm{NaCl}$ dominated. Profiling and purging of wells suggested that water quality measurements reflected aquifer conditions in most situations. Water chemistry appeared to have limited influence on stygofauna occurrence in the Pilbara. Geology also appeared to have little effect on stygofauna occurrence but this may have been the result of non-random siting of wells; there was a bias towards wells being in transmissive locations that were not necessarily typical of the geology in which each well occurred.

No potential reserves for stygofauna are recommended in this paper but nine areas of high stygofauna richness were identified, including the listed Ethel Gorge stygofauna community. Theoretical analysis of species ranges suggested that half of the species found only in the vicinity of development projects will have ranges less than $680 \mathrm{~km}^{2}$. Consequently, projects involving extensive groundwater drawdown (sometimes through the interaction of de-watering operations at adjacent projects) have the potential to affect a large proportion of the population of a restricted species or to threaten the persistence of species with particularly small ranges.

Keywords - subterranean fauna, stygobite, sampling, groundwater, distributions, Western Australia 


\section{INTRODUCTION}

The global volume of groundwater is approximately 30 times greater than the volume of non-marine surface water (Gleick 1993). This disparity is even greater in arid regions, such as the Pilbara of Western Australia, where there is relatively little surface water but vast amounts of fresh groundwater (Johnson and Wright 2001). Consequently, groundwater comprises by volume almost all of the aquatic habitat of the Pilbara, although surface claypans, river pools and springs are highly biodiverse (Pinder et al. 2010).

Some surface-water animals make use of groundwater where it discharges from springs or seeps into river pools through the streambed. However, animals using groundwater at greater depths are referred to as stygofauna and most show some modifications to subterranean life and the absence of light. Classically, the adaptations include loss of eyes and pigment, elongation of appendages and sensory structures, and a vermiform body shape (Christiansen 1961). Nearly all stygofauna are invertebrates (Gibert et al. 1994) and they are often classified into three broad categories according to their dependence on groundwater (Camacho 1992; Sket 2008). Stygobites spend their full life cycle in groundwater; stygophiles either have a life stage in epigean habitats or some of their populations occur in surface water; stygoxenes are facultative users of groundwater that are found mostly in epigean habitats.

The early history of stygofauna research in Western Australia is similar to that in other parts of the world, with the species discovered prior to the 1990s mostly being collected by speleologists in caves, or from wells in highly karstic environments (e.g. Holthuis 1960; Whitely 1945). However, the direction of research changed in the early 1990s, when W.F. Humphreys began extensive survey work at the Cape Range, Barrow Island and then in the Pilbara region (Adams and Humphreys 1993; Humphreys 2000, 2001a, 2008). This pioneering work, which mostly involved sampling pastoral wells, showed that the Pilbara of Western Australia contains a rich, diverse array of stygofauna species across the landscape matrix rather than in caves (Eberhard et al. 2005a). It was found that relictual species from both previous Tethyan (e.g. Poore and Humphreys 1992, 1998) and Gondwanan (e.g. Knott and Halse 1999; Karanovic, T. 2006) alignments of the Pilbara persist in the region's current stygofauna communities. In addition, the Pilbara stygofauna community contains some highly distinctive and endemic elements (e.g. Karanovic, I. 2007).
Since the late 1990s, there has been growing awareness that some species in the rich Pilbara stygofauna communities may be threatened by mining developments. Western Australia is historically the third largest producer of iron ore $(17 \%$ of global production) after China (25\%) and Brazil (20\%) (DMPR 2001), with substantial increases in production underway. More than $95 \%$ of Western Australian iron ore is extracted from the Pilbara in large, open-pit mining operations that usually require removal of groundwater (de-watering) to provide access to ore below the water table (Johnson and Wright 2001). Dewatering may result in groundwater drawdown of several hundred metres (e.g. EPA 2009). This threat to stygofauna has been recognised by the Environmental Protection Authority and a requirement to consider impacts on stygofauna is incorporated into the environmental assessment process for new mines and other developments affecting groundwater (EPA 2003, 2013).

Evaluating the likely impact of a development on stygofauna is much easier if the distribution of stygofauna species and the factors affecting their occurrence are known. Accordingly, stygofauna were included as a survey element of the Pilbara Biodiversity Survey (McKenzie et al. 2009). As a program, the Pilbara Biodiversity Survey had the following objectives:

1. To collect systematic baseline data on the current distribution of biota across the region to provide a regional perspective on nature conservation priorities and a framework for future monitoring of regional-scale trends in occurrence.

2. To improve understanding of the factors influencing plant and animal distributions and to provide a context for assessing the conservation status of species and communities and the significance of localised occurrences of species.

3. To identify gaps in the coverage of the reserve system for species and communities and to identify areas where reservation will efficiently improve the reserve system according to three criteria: comprehensiveness (i.e. all regionalscale ecosystems included), adequacy (i.e. sufficient areas reserved to be viable) and representativeness (i.e. fine scale variability within ecosystems incorporated into reserves).

The stygofauna survey program focused on the first two objectives of the Pilbara Biodiversity Survey (collection of baseline data and providing context for assessment). At this stage, the third objective (improving the reserve system) is difficult to achieve for stygofauna, partly because stygofauna can be sampled only after wells or drill 
holes are in place. These are most abundant in areas intended for development.

The survey was directed at invertebrate stygofauna, which were the only stygofauna species known from the Pilbara when the survey was planned. Subsequently the blind eel, Ophisternon candidum, was collected near Bungaroo Creek by Biota Environmental Sciences (EPA 2012), although this record has not been formally published and evaluated. The blind eel also occurs in the Cape Range, together with the blind cave gudgeon, Milyeringa veritas (Humphreys 2001a). A species of blind eel and another species of blind gudgeon, $M$. justitia, have been collected from Barrow Island off the Pilbara coast (Larson et al. 2013).

\section{METHODS}

\section{Study area}

For the purposes of the stygofauna survey, the Pilbara region was considered to be bounded to the south by the main channel of the Ashburton River and to the north-east by the De Grey/ Oakover River and its tributaries (Figure 1). This area of about $261,144 \mathrm{~km}^{2}$ includes all the Pilbara region as recognised in the Interim Biogeographic Regionalisation for Australia (IBRA) and parts of the Augustus and Ashburton subregions of the northern Gascoyne IBRA region (Environment Australia 2008). McKenzie et al. (2009) provide a summary of the region's landforms, geology and climate.

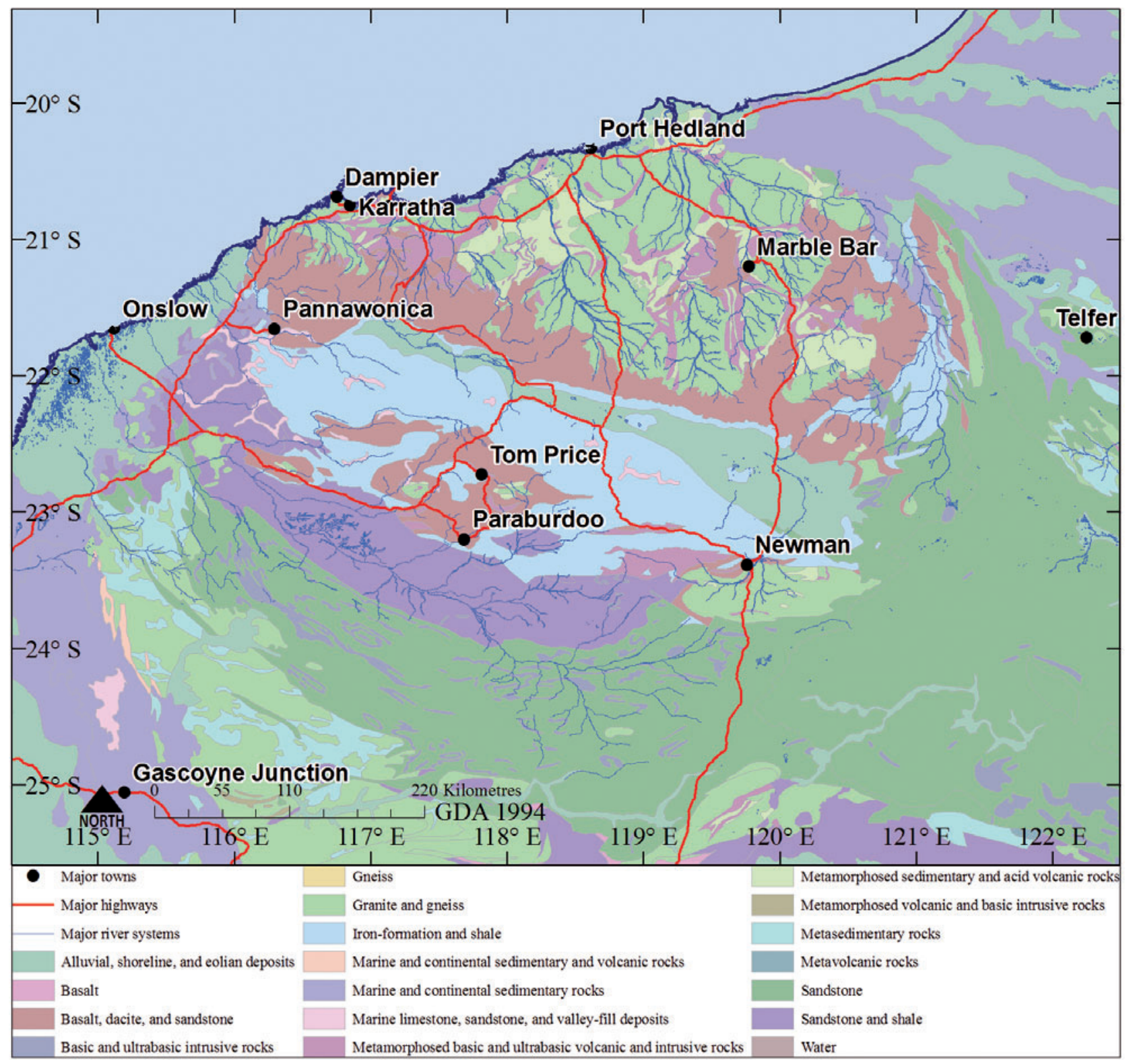

Figure 1 Surface geology of the Pilbara, stygofauna survey boundary and selected locations. 
The Pilbara is hot and dry, with the annual rainfall in most areas $(250-300 \mathrm{~mm}$, decreasing inland) outweighed 10:1 by evaporation. Most rainfall occurs in monsoonal thunderstorm or cyclonic events during summer, although winter rainfall is sometimes significant in coastal areas. Mean summer minimum and maximum temperatures are $25^{\circ} \mathrm{C}$ and $36^{\circ} \mathrm{C}$, respectively, while mean winter temperatures are $12^{\circ} \mathrm{C}$ and $27^{\circ} \mathrm{C}$.

The Pilbara Craton, one of Australia's major geological blocks (Geological Survey of Western Australia 1990), largely coincides with the Pilbara region. The Craton is characterised by hard rock landscapes that were laid down in Archaean times, and part of the Craton formed the earliest known emergent landmass about 3.5 billion years ago (Buick et al. 1995). The Archaean basement rock is exposed as granite and greenstone terrain in the northern Pilbara but is overlain by rugged sedimentary strata, volcanic flows and lateritised caps in the southern Pilbara. Importantly from a biogeographic viewpoint, most of the Craton has been emergent throughout the earth's history of continent formation and break-up (Johnson 2004).

There is little permanent surface water in the Pilbara and all rivers are ephemeral (Pinder et al. 2010). Nevertheless, river systems are extensive, with five drainage basins recognised: the Ashburton, Robe, Fortescue, Port Hedland Coast and De Grey (Figure 1). These basins mostly contain three types of groundwater aquifers that potentially provide habitat for stygofauna: (1) unconsolidated sedimentary aquifers, including those in recent valley-fill alluvium and colluvium, and coastal deposits; (2) aquifers in chemicallydeposited calcretes and pisolites within Tertiary drainage channels; and (3) fractured-rock aquifers in dolomites, banded-iron formations (BIF), granite and other rocks (Johnson \& Wright 2001). Aquifers in calcrete and pisolite are often associated with alluvial aquifers and alluvium is a prominent feature of all drainage channels.

Groundwater in the Pilbara is mostly fresh (200-1500 $\mathrm{mg} \mathrm{L}^{-1}$ ) and often bicarbonate-dominated, although $\mathrm{NaCl}$-rich waters are common in both the coastal and arid eastern margins. Water under the Fortescue Marsh in the central part of the Fortescue basin is hypersaline and dominated by $\mathrm{NaCl}$. Recharge to the groundwater aquifers is principally via cyclonic rain (Dogramaci et al. 2012) but there is also some seepage during peak flow periods from rivers and creeks to alluvial aquifers. Depth to groundwater is highly variable, with groundwater discharging to the surface at springs and in the beds of many large river pools, although the latter is usually water stored in the channel alluvium rather than groundwater from regional aquifers (Fellman et al. 2011). Away from watercourses, groundwater is mostly $5-20 \mathrm{~m}$ below ground level (bgl) across the coastal plain and often more than $40 \mathrm{mbgl}$ in the Hamersley and Chichester Ranges. A fuller account of groundwater conditions is provided by Reeves et al. (2007).

The occurrence of stygofauna in an aquifer is regarded as being controlled largely by the types of voids and interstitial spaces present, and by groundwater chemistry (Danielopol et al. 2003). Both these attributes are influenced by the host geology of the aquifer, the amount of landscape weathering, and local chemical and hydrological processes (Reeves et al. 2007).

\section{Survey design and methods}

Stygofauna survey began in 2002 and continued until 2005. A total of 1053 samples was collected from 507 wells and drill holes across the Pilbara that intersected groundwater (Figure 2, Appendix 1). These holes were mostly wells installed by government agencies, pastoralists or mining companies. Thirty-six wells were sampled once, 441 were sampled twice, and 30 wells were sampled more frequently to examine the efficiency of sampling methods (see Eberhard et al. 2009) or in an attempt to collect particular species.

Eleven 'sub-regions' across the Pilbara were identified for the purpose of ensuring stygofauna sampling effort was geographically well spread (Figure 2). The sub-regions were based on the major river basins, although the Robe basin was combined with the Fortescue to reflect the past connection of these basins. The diversion of the lower Fortescue away from the Robe River most likely occurred since the Last Glacial Maximum (Barnett and Commander 1985). The identification of sub-regions within the basins was based on distance from the coast, topography and geology. Insofar as possible, sampling effort was distributed evenly across the sub-regions (65-109 samples in each). In addition to the 11 sub-regions, small areas to the north (Eighty Mile Beach), east (Great Sandy Desert), south (north-east Gascoyne) and southwest (Carnarvon) were sampled to provide some biogeographic context for the results of the Pilbara sampling. Twelve to 27 samples were collected from each of these areas.

While an attempt was made to include as many different geologies as possible in the survey, the use of existing wells biased the sampling towards aquifers that yielded high volumes of fresh water. Consequently, more samples were collected from alluvium, colluvium and calcrete than would be expected from the spatial occurrence of these geologies in the Pilbara.

\section{Wells}

Nearly all the wells sampled for stygofauna were cased and slotted because uncased wells and drill holes caused frequent loss of equipment. 


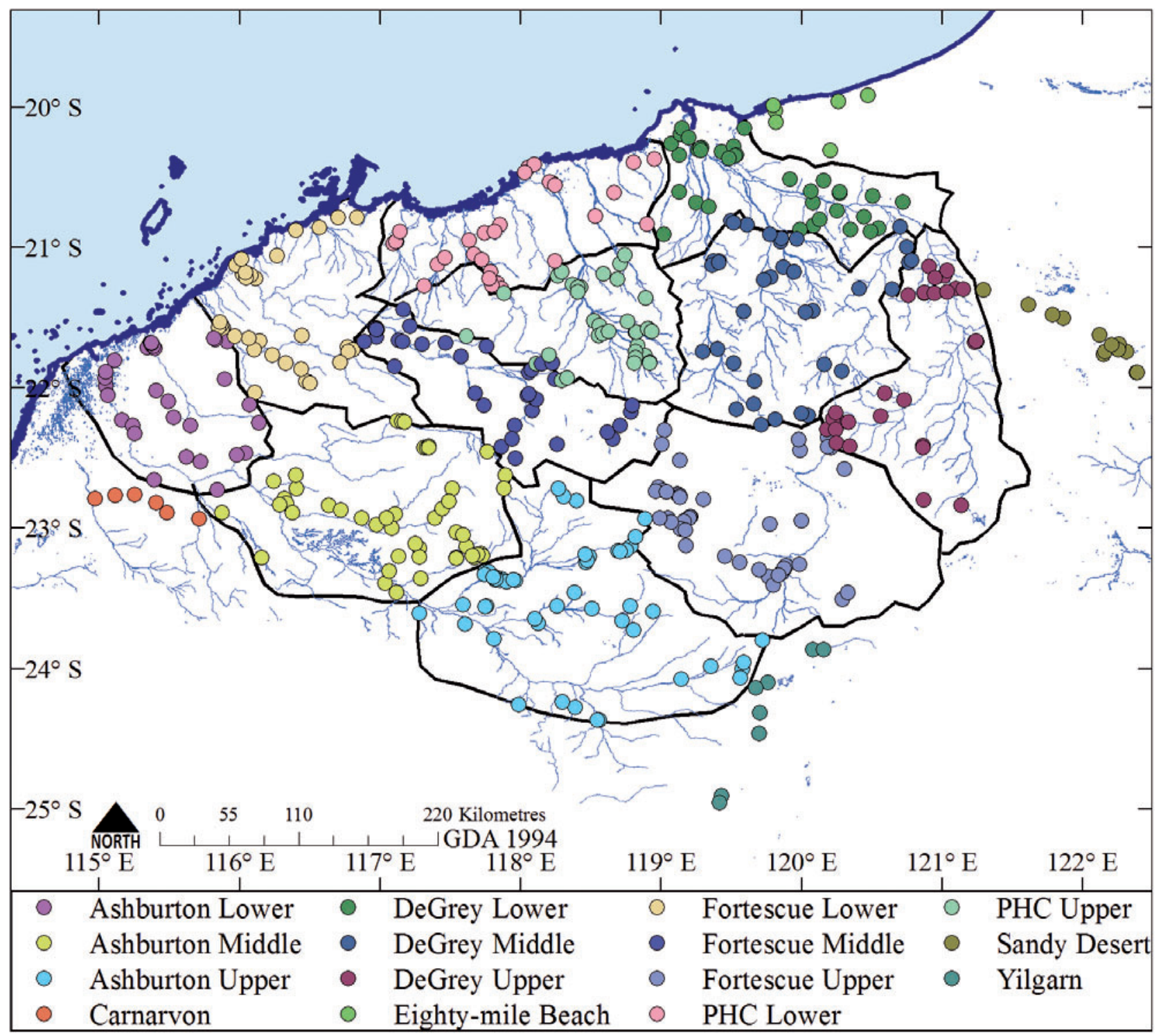

Figure 2 Locations of wells sampled across the Pilbara, with sampling sub-regions outlined (see text for explanation of sub-regions).

Wells ranged in diameter from $50 \mathrm{~mm}$ to about 2 $\mathrm{m}$. The larger wells were mostly older, located on shallow watertables, hand-dug and lined with rock. Narrower wells were cased either with polyvinyl chloride (PVC) or steel and slotted below the watertable in a variety of ways to enable exchange of water between the bore and the surrounding aquifer. A high proportion of the wells sampled were either monitoring or production wells and were slotted for most of their underwater length. A small proportion were piezometers and, thus, were slotted at particular depths. Details of slotting and the screens used in well construction were usually not available and no attempt was made to evaluate whether slot and screen sizes affected faunal yields, other than noting that large animals were frequently present in wells with standard (0.5-1 $\mathrm{mm}$ ) slotting. All the wells sampled were more than 6 months old and most were capped (i.e. the casing or a collar at the top of the well was sealed at the surface to prevent animals and material falling into the well).

\section{Sampling methods}

Prior to fauna sampling, electrical conductivity (EC), $\mathrm{pH}$, redox and dissolved oxygen (DO) were measured in each well using a Yeo-Kal 611 water quality analyser lowered to $1 \mathrm{~m}$ below the watertable (referred to as standing water level, SWL). Depths to SWL and the base of the well were measured with a Richter Electronic Depth Gauge or weighted Lufkin tape measure. 
Water was also collected from $1 \mathrm{~m}$ below SWL using a sterile bailer (Clearwater PVC disposable $38 \times 914 \mathrm{~mm}$ ) and a $250 \mathrm{ml}$ sample was collected for analysis of total dissolved solids (TDS), ionic composition, alkalinity, colour and turbidity. A second $125 \mathrm{ml}$ sample was collected, and frozen in the field, for analysis of total soluble nitrogen, nitrate/nitrite, total soluble phosphorous and soluble reactive phosphorous by ChemCentre using the laboratory methods of APHA (1995). All analyses occurred within one month of collection.

Stygofauna were collected with small haul nets, made from either 50 or $150 \mu \mathrm{m}$ mesh, with a glass collecting vial at the base within a brass weight (Eberhard et al. 2005b). The base of the glass vial was removed and replaced with $50 \mu \mathrm{m}$ mesh to improve water flow through the net. At each well, a stygofauna sample was collected by lowering the net to the end of the well, bouncing the net several times to stir up sediment and slowly retrieving it. The contents of the vial were then transferred into $100 \%$ ethanol. Three hauls with the $50 \mu \mathrm{m}$ mesh net and three hauls with the $150 \mu \mathrm{m}$ mesh net were made for each sample.

After each sampling, nets were washed in Decon90, rinsed in deionised water and air-dried to prevent the transfer of stygofauna between bores during the survey.

\section{Stygofauna sample processing and identification}

Prior to sorting under a dissecting microscope, samples were separated in the laboratory into three size fractions by sieving through 250,90 and $53 \mathrm{~mm}$ Endecott sieves to facilitate searching for preserved stygofauna. All stygofauna taxa collected were identified to the lowest taxonomic rank possible using published and informal keys, the aim being to achieve species or morpho-species identification. Where necessary, animals were dissected and examined under a compound microscope to achieve identification. The numbers of individuals of each taxon present were recorded using a logarithmic scale $(1=1-10$ animals, $2=11-100$ animals etc.) and adjusted to midpoint log values of $0.7,1.7$ etc. for analyses involving abundance.

As part of the survey, and to facilitate identification, taxonomic work was instigated on copepods (Karanovic, I. 2006; Tang et al. 2008), ostracods (Karanovic, I. 2007) and isopods (Keable and Wilson 2006; Bruce 2008) and water mites (M.S. Harvey unpublished). Existing work on amphipod taxonomy was supported (Finston et al. 2007, 2011).

\section{Profiling and purging wells}

The correspondence between the physicochemical data collected $1 \mathrm{~m}$ below SWL in wells and the surrounding aquifer was investigated in 34 bores in the western half of the Pilbara during 2005 and 2006. Approximately half of the wells were investigated each year (Table 1). Three types of data were collected:

(1) Measurements of $\mathrm{EC}, \mathrm{pH}$, temperature and DO were made at approximately $1 \mathrm{~m}$ intervals for the length of the water column in all wells. The purpose of this profiling was to determine whether measurements made $1 \mathrm{~m}$ below SWL were representative of conditions throughout the water column.

(2) Data on EC, $\mathrm{pH}$, ionic composition and nutrients were collected from six wells $1 \mathrm{~m}$ below SWL before and after these bores were purged. Purging consisted of pumping out three times the volume of water occurring in the well so that the water column was entirely replaced by water from the surrounding aquifer. The purpose of these measurements was to determine whether water in the well was representative of water in the surrounding aquifer or whether atypical conditions exist within the well that may have favoured a few stygofauna species.

(3) In 2005 profiling was repeated after an interval of four months at three wells that exhibited marked vertical variation in their profiles to determine whether profiles were stable across seasons. The profiles of two wells were re-examined in 2006.

\section{Data analysis}

Unless stated otherwise, all analyses were based on the first two samples taken from each of 471 wells, plus the single samples from 36 wells. This was done to prevent analyses being biased by wells with unusual characteristics that were sampled on multiple occasions (Eberhard et al. 2009).

\section{Water chemistry}

Water samples were classified based on values of the parameters $\mathrm{EC}, \mathrm{pH}$, and major ions $(\mathrm{Na}$, $\mathrm{K}, \mathrm{Ca}, \mathrm{Mg}, \mathrm{Mn}, \mathrm{Cl}, \mathrm{HCO}_{3} / \mathrm{CO}_{3^{3}} \mathrm{SO}_{4}$ expressed in milliequivalents $\mathrm{L}^{-1}$ ). Samples with more than $15 \%$ difference between the milliequivalent sums of cations and anions were excluded from analysis (APHA 1995). Parameters were range standardised and dissimilarity between samples was calculated using the Gower metric. The UPGMA option with default settings in the PATN multivariate analysis package (v. 3.12, http://www.patn.com.au) was used to perform the classification. Results were examined in an ordination plot using the SSH procedure and the PCC option was used to show correlations of the water chemistry parameters with ordination space.

Differences in water chemistry among the 


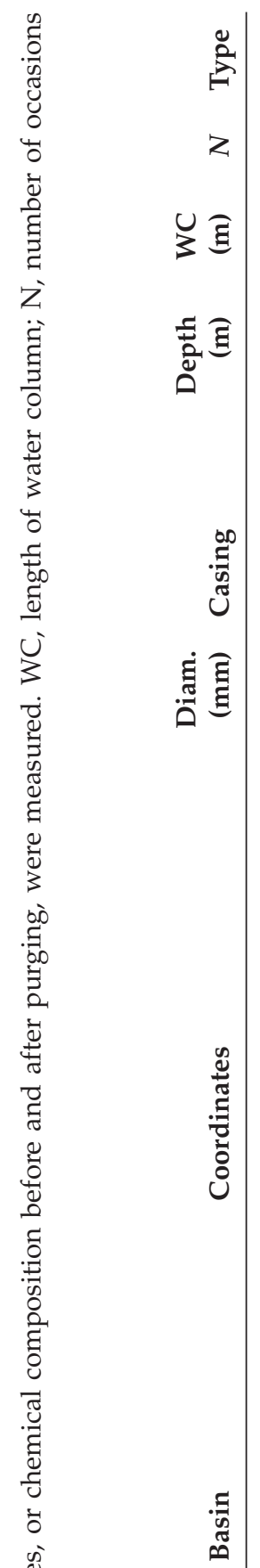

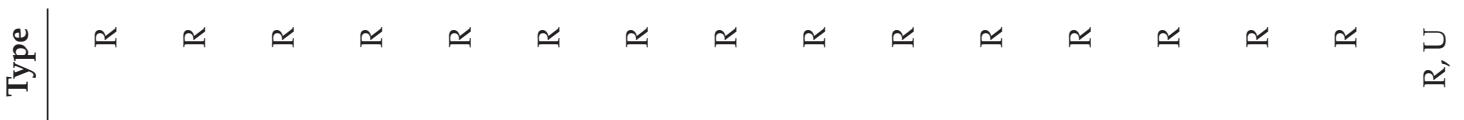

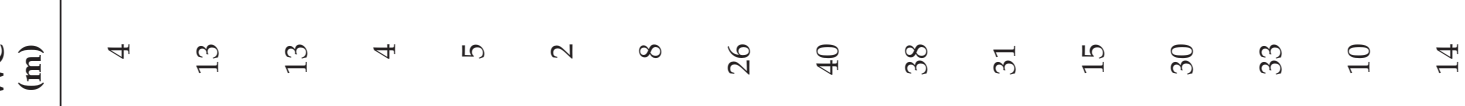

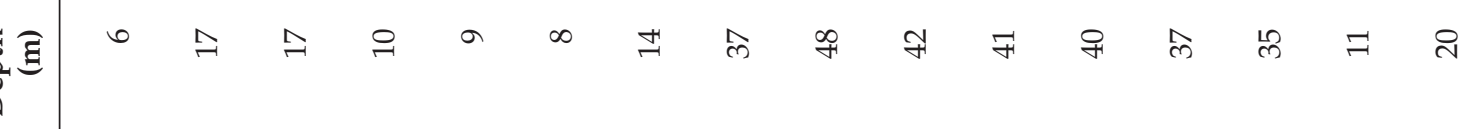

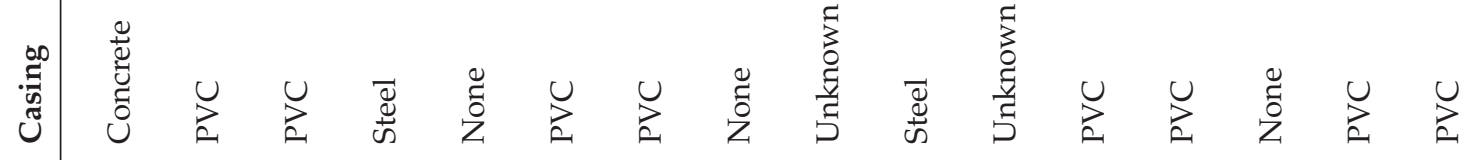

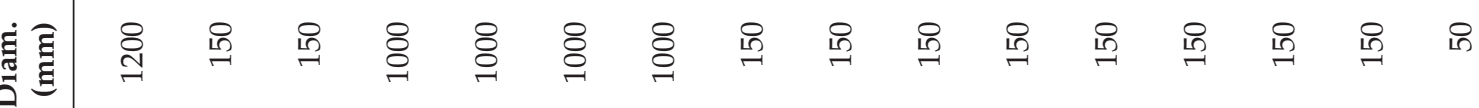

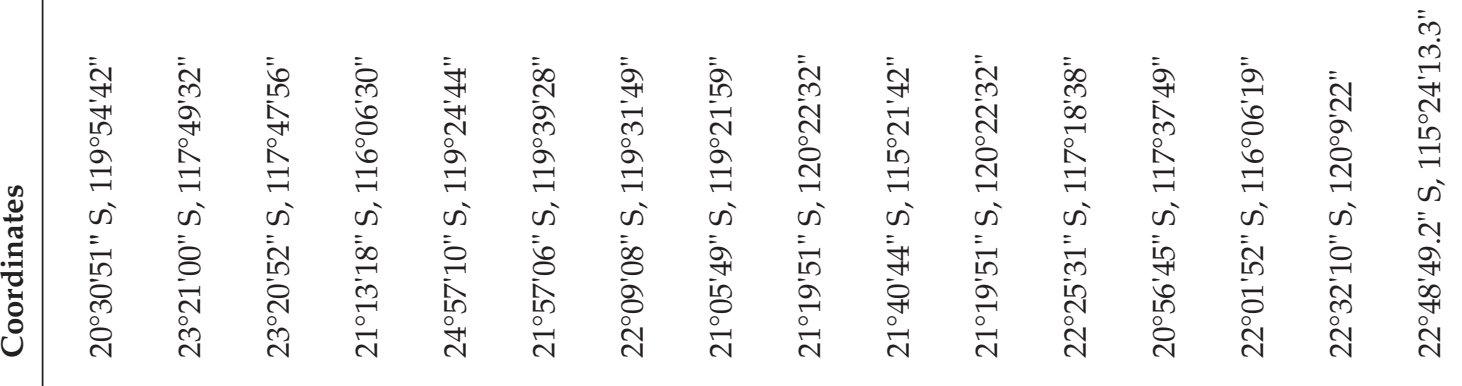

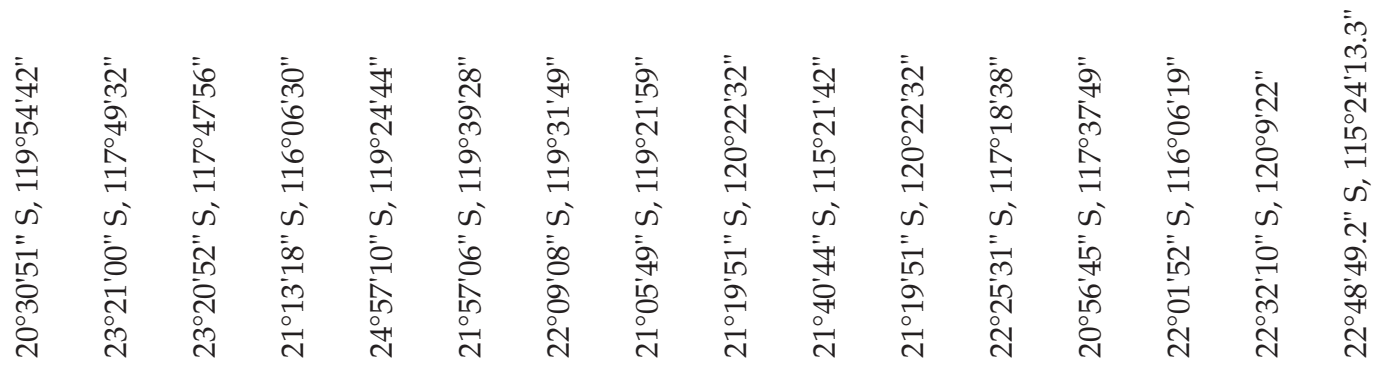

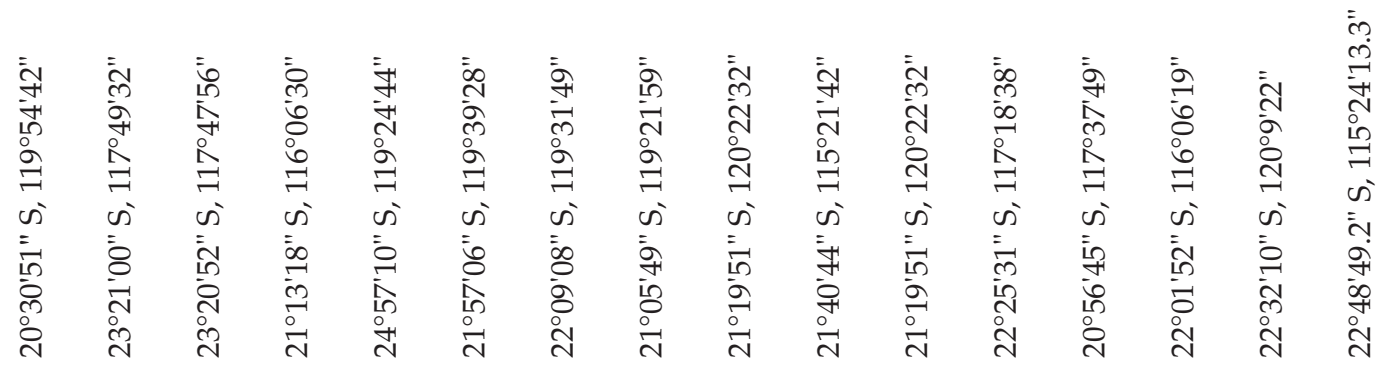

造

t.

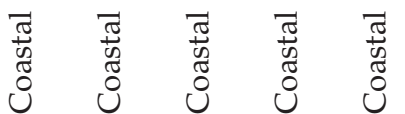

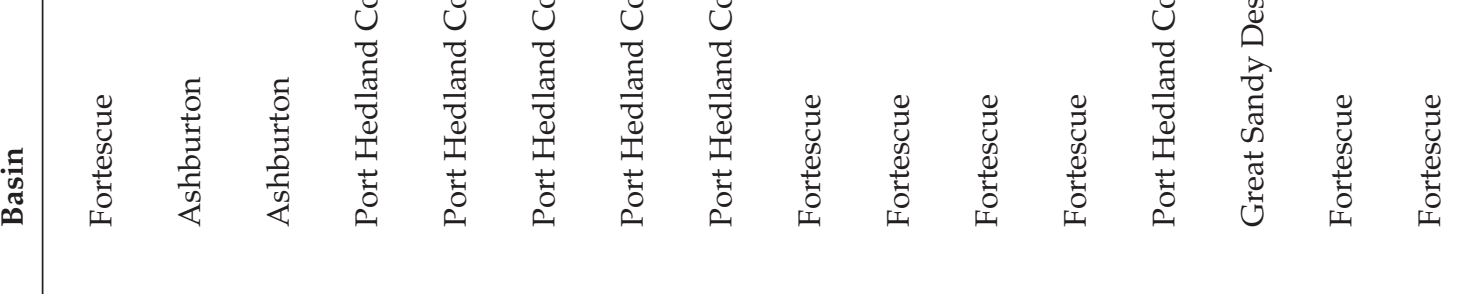

है

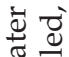

$3 \frac{0}{0}$

ป气

$3 \simeq$

: ت্ষे

常言

लำ

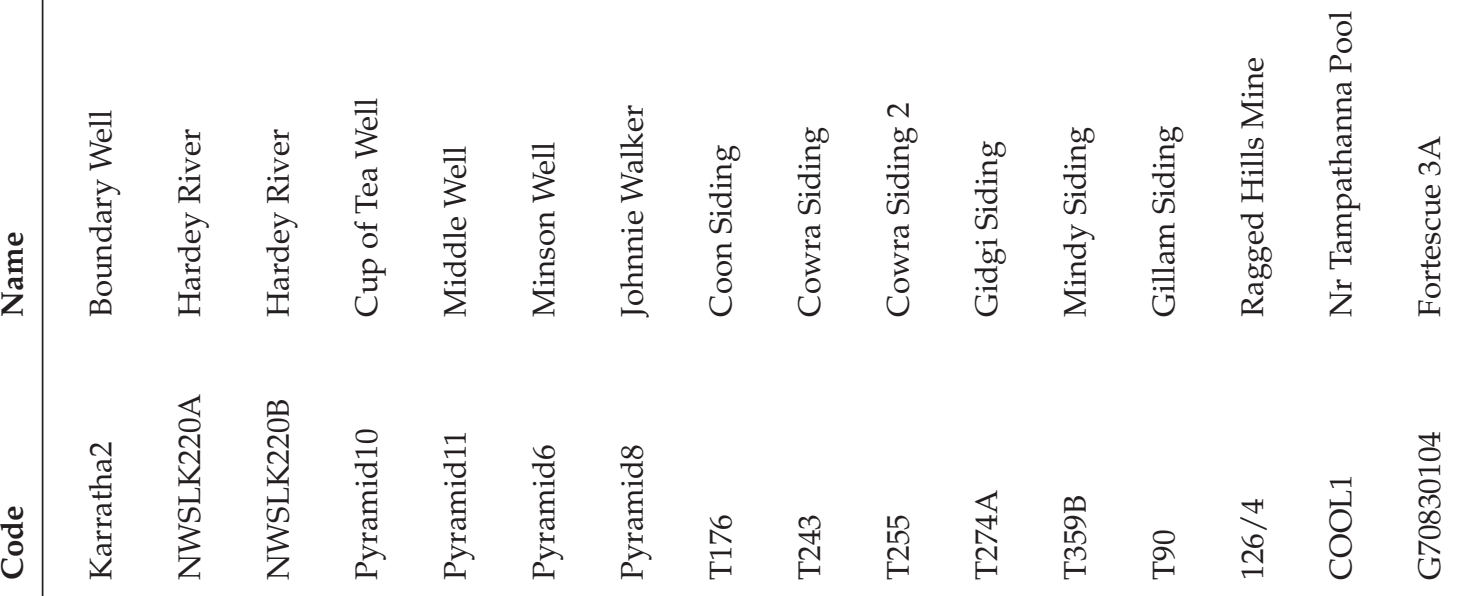




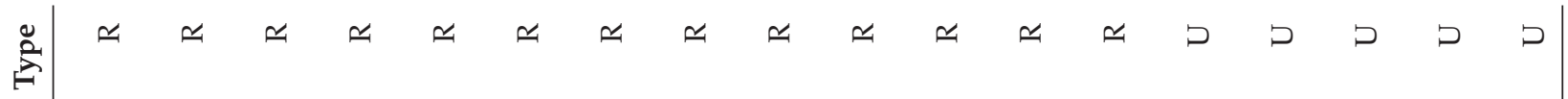

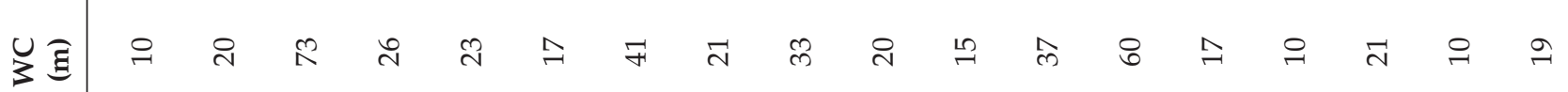

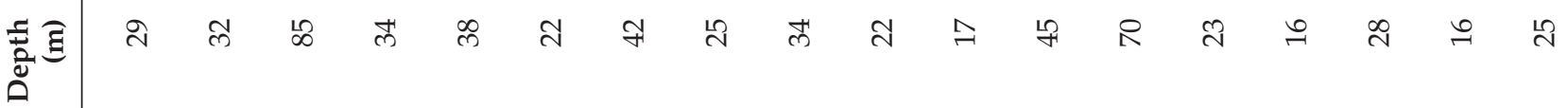

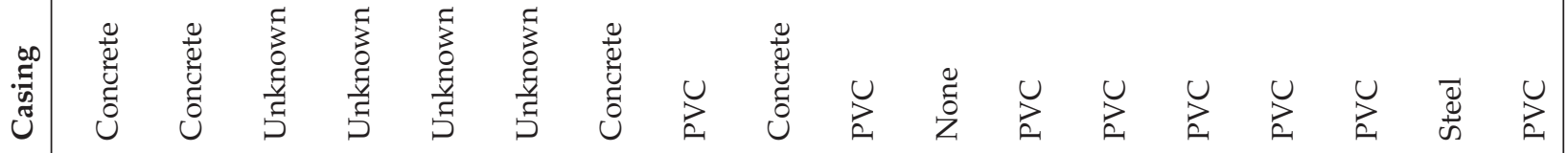

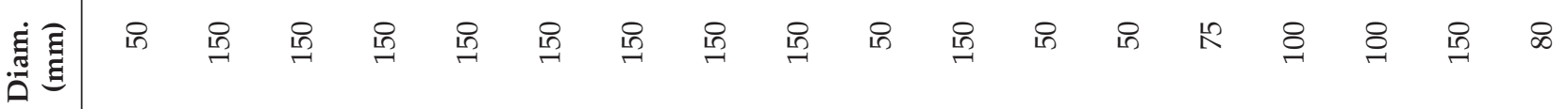

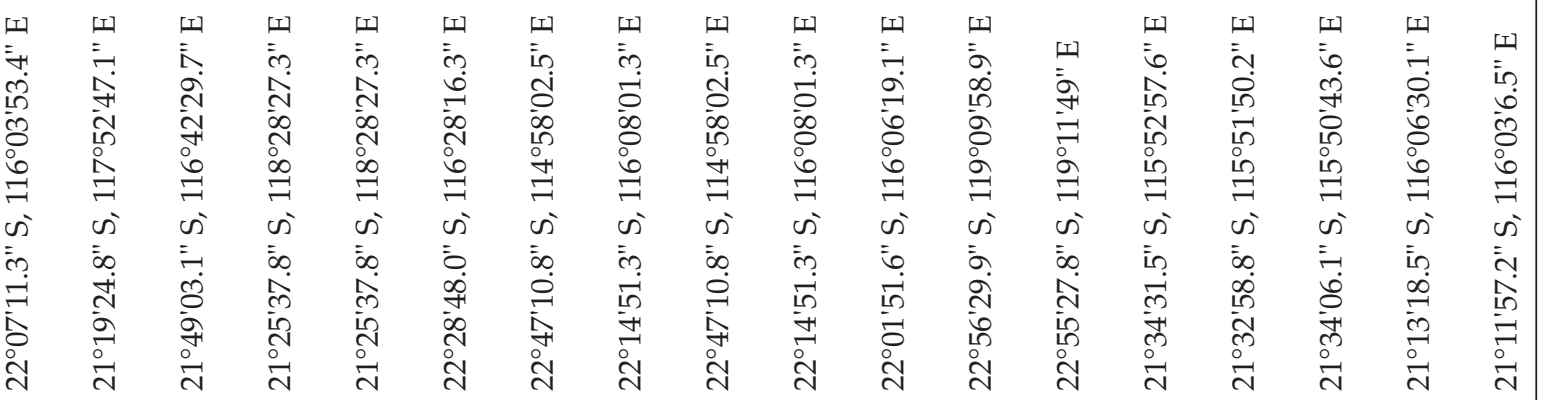

$$
\begin{aligned}
& \text { 节 }
\end{aligned}
$$

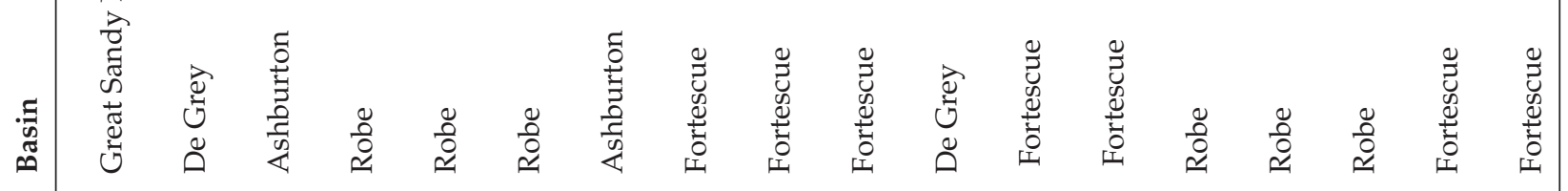

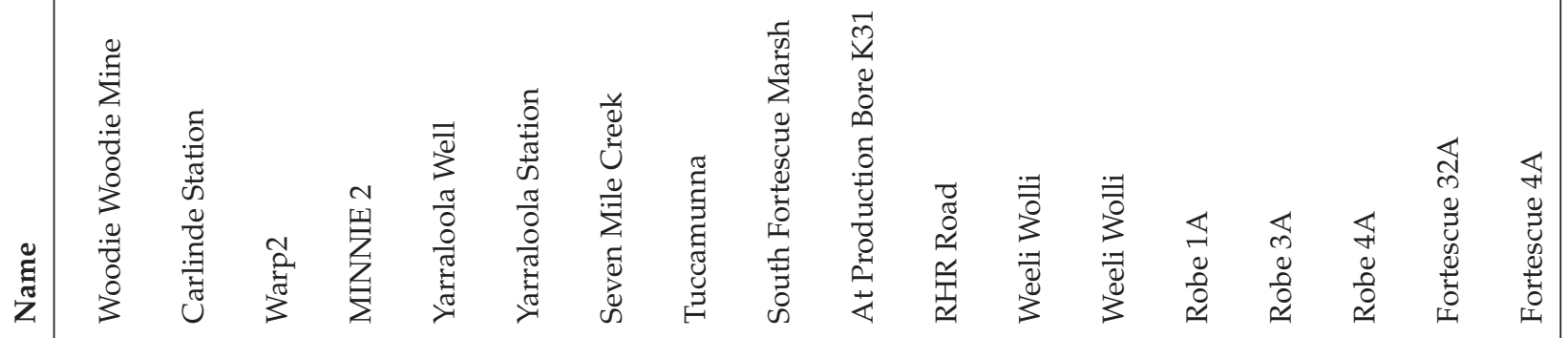

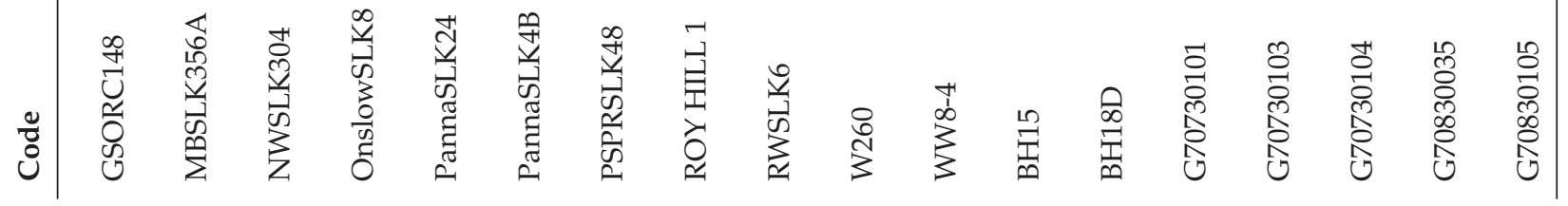


Table 2 Geological categories used in analysis of stygofauna abundance and richness. Numbers of wells in each category are shown.

\begin{tabular}{lr}
\hline BIF & 16 \\
Calcrete & 55 \\
Granitic instrusives & 31 \\
Mafic volcanics & 29 \\
Quaternary alluvials & 507 \\
Sedimentary & 49 \\
Tertiary detritals & 172 \\
\hline
\end{tabular}

main groups of samples were examined by one-way ANOVA for each parameter. When necessary, data were log-transformed to achieve homoscedasticity and approximately normal distributions. Manganese was omitted from this analysis because it is not a major ion.

\section{Factors affecting species occurrence}

The relationship between overall stygofauna abundance in a sample and the number of species present was examined by assigning samples to the log abundance category of the most abundant species in the sample. A one-way ANOVA was used to test whether there were overall differences in species richness across the log abundance categories and a Tukey's HSD range test was used to examine the significance of differences between log abundance categories.
Differences in numbers of species and animals in samples belonging to different sub-regions, water chemistry groups and geologies were examined by one-way ANOVA. The seven broad categories of geology used in this analysis represent an aggregation of the units used on 1:250,000 geological map sheets by independent geological experts with the aim of amalgamating units possessing similar structure and geological history (Table 2).

Relationships between species richness in wells and their diameter, casing, distance from the coast, depth to SWL, salinity, nutrient concentration and DO were examined by one-way ANOVA or correlation analysis. The relationship between presence of casing and the numbers of species collected from wells was examined in the Fortescue basin using a small sub-set of survey wells and larger sets of wells sampled after completion of the survey by Bennelongia Environmental Consultants using the same collecting techniques and staff as the stygofauna survey (Table 3).

\section{Temporal variability}

Variation in the number of stygofauna species collected by the two samples from a well was examined in two ways. First, the number of species collected in the second sample was plotted against the number in the first sample to see how well species richness could be predicted from the first sample. Second, the number of species collected per sample in autumn and spring was compared using one-way ANOVA. Autumn was defined as April to June and represented the period when summer and autumn cyclonic and monsoonal rainfall was likely to be recharging the aquifer. Spring was defined as September to November and represented a period with dry soil and declining groundwater levels. Samples collected in July and August were omitted from the second analysis.

Table 3 Number of wells sampled in the vicinity of the Fortescue Lower and Fortescue Middle sub-regions to examine effect of casing on species yield during sampling. Bennelongia Environmental Consultants' (BEC) data represent collecting in 2007 around Fortescue Lower and from 2007-2010 around Fortescue Middle in wells of 50-100 mm diameter.

Fortescue Lower

Survey BEC data Survey BEC data

\begin{tabular}{lcccc}
\hline Uncased & 0 & 28 & 2 & 35 \\
Cased & 24 & 19 & 95 & 202 \\
Total & 24 & 47 & 97 & 237 \\
\hline
\end{tabular}




\section{Community composition}

In order to examine whether various, distinctly different stygofauna communities occur across the Pilbara, stygofauna samples were displayed in a three-dimensional ordination plot using order level taxonomy, the Bray Curtis dissimilarity measure and the SSH procedure in PATN. Initial species level ordination plots revealed no pattern and many sites with stygofauna had to be deleted because they shared no species with other sites. In the order level ordination, samples containing either no stygofauna or only one order of stygofauna were omitted from analysis, leaving 545 samples. Prior to ordination, the samples were classified into 10 groups of 'similar' composition using UPGMA, with the Bray Curtis dissimilarity measure and $\beta=-0.1$.

\section{Kriging}

Although the stygofauna survey was a very large effort, the density of wells sampled was low (an average of 0.002 wells $\mathrm{km}^{-2}$ ). In an attempt to identify the pattern of stygofauna richness at a finer scale than sub-regions, a species richness 'surface' was fitted across the Pilbara by ordinary kriging using the gstat package and gstat() module in the statistical package R (Crawley 2007; http:// casoilresource.lawr.ucdavis.edu/drupal/node/442). The average number of species collected in the one or two sampling events was used as the richness measure for each well. The semivariogram needed for the interpolation was estimated via the exponential method using a $200 \times 200$ grid of evenly spaced points across the Pilbara that was trimmed to match the area of interest.

\section{Number of species in the Pilbara}

Using data from the survey being reported here, Eberhard et al. (2009) estimated the number of stygofauna species in the Pilbara to be 500-550, assuming that no additional species were recognised as a result of further taxonomic discrimination (in fact, further taxonomic discrimination will add species). The accuracy of the estimate of 500-550 was examined by comparing the number of species collected during the stygofauna survey with the number collected during more recent and intensive surveys of two areas in the Fortescue Lower and Fortescue Middle sub-regions. In both areas, the additional wells sampled lay within the area sampled during the survey, although the additional sampling had a different geological bias (Figure 3). In the Fortescue Lower sub-region, 24 wells were sampled during the survey and 47 subsequently using the same techniques and staff, while in the Fortescue Middle sub-region 97 wells were sampled during the survey and 257 subsequently (Table 3, see also Bennelongia 2008, 2012a). Species accumulation curves for the four sets of samples collected were constructed using EstimatesS (Colwell 2006).

\section{Species distributions}

The likely range of a species is an important issue in environmental assessment because the risk of a species being made extinct by anthropogenic change is considered to be much higher for species with small ranges (Ponder and Colgan 2002; Payne and Finnegan 2007). Both the low sampling density and the fact that the wells sampled were often clustered in nodes (Figure 2) may have caused ranges of many species to be underestimated in this, and other, surveys and their conservation significance is consequently overstated. To obtain an alternative view of the likely spatial extent of a species restricted to a single sub-region, we assumed the sub-region and species' range were squares with sides of $\mathrm{S} \mathrm{km}$ and $\mathrm{R} \mathrm{km}$, respectively, and then solved the following equation for $\mathrm{R}$ when $p=50$.

$$
(\mathrm{S}-\mathrm{R})^{2} /(\mathrm{S}+\mathrm{R})^{2}=p / 100
$$

This solution provides the median range of a species restricted to a single sub-region. Fifteen sub-regions were recognised in this analysis; 11 in the Pilbara and four on the periphery (Figure 2). We concede that some of the assumptions behind the calculation may be considered unrealistic, in particular that species ranges are not determined by hydrological or geological boundaries, but defend the calculation as an effort to obtain range information in a way that was independent of the bias in much of our sampling. We suggest the result provides useful background information about species ranges for environmental impact assessment in the Pilbara.

\section{RESULTS}

\section{Water chemistry}

PATN analyses indicated that groundwater samples from wells were best classified into 10 groups along gradients of salinity, $\mathrm{pH}$ and ionic composition (Figure 4, Table 4). Samples ranged from being weakly saline (WG1) to very fresh (WG8, WG10). Only two groups of samples were $\mathrm{NaCl}$-dominated (WG1, WG2), although $\mathrm{Na}^{+}$ was the dominant cation in an extra two groups (WG4, WG7). $\mathrm{Ca}^{2+}$ was dominant in WG3, and co-dominant with $\mathrm{Mg}^{2+}$ in WG8, whereas $\mathrm{Mg}^{2+}$ was dominant in WG9 and, to a less extent, in WG5. In addition to WG1 and WG2, $\mathrm{Cl}^{-}$was the dominant anion in WG3 and co-dominant with $\mathrm{HCO}_{3}^{-}$in WG4. $\mathrm{HCO}_{3}^{-}$was dominant in WG7-10, with a significant amount of $\mathrm{CO}_{3}{ }^{2-}$ present in WG 9. In WG5 and WG6, $\mathrm{SO}_{4}{ }^{2-}$ was the dominant anion. WG6 contained a single sample of fresh water from well MBSLK124, south of Nullagine in the upper Fortescue catchment, and was distinct from other samples with a pH of 4.85 (Table 5). 


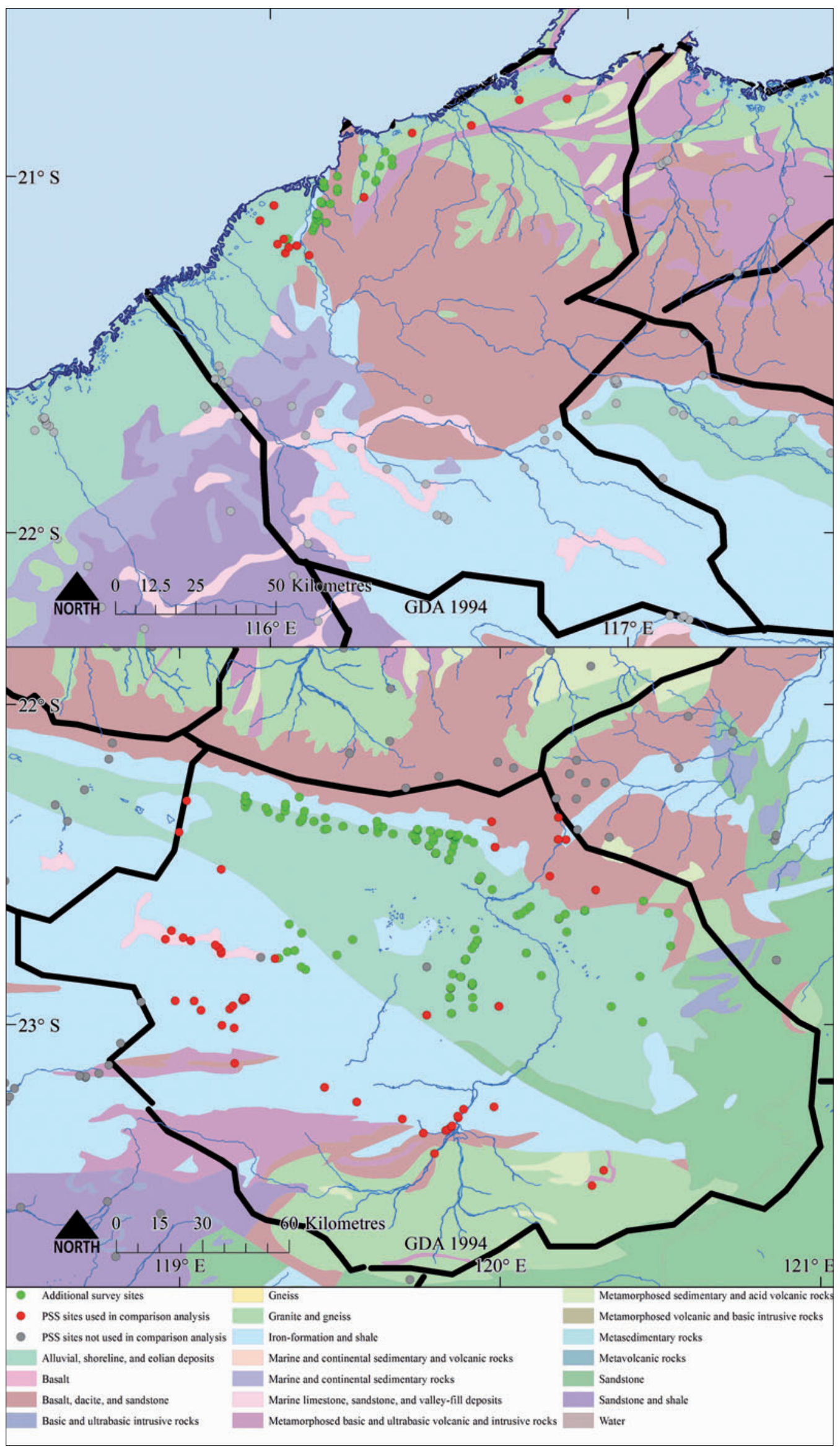

Figure 3 Areas of intensive sampling in Fortescue Lower and Fortescue Middle sub-regions. 


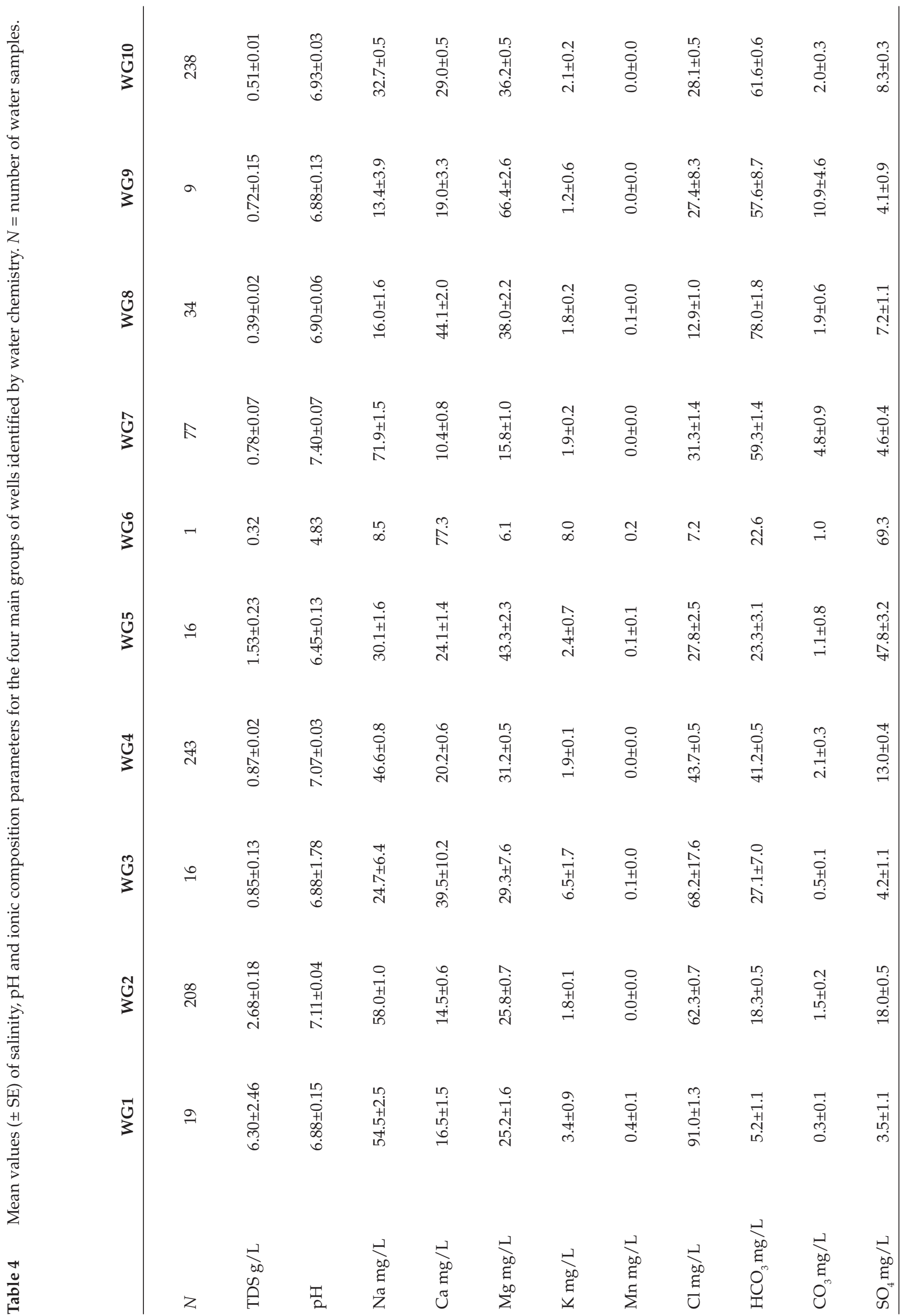




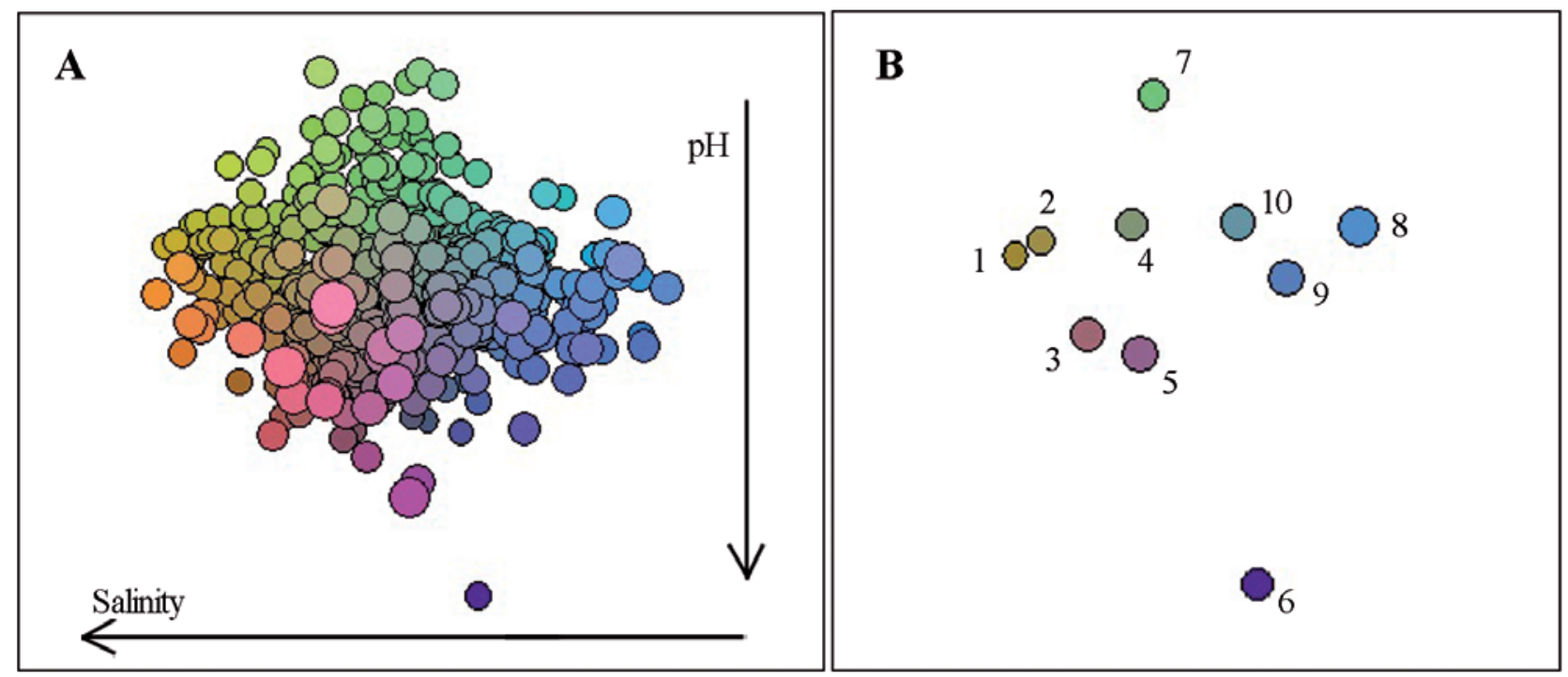

Figure 4 Three-dimensional SSH ordination of water samples.

A, all samples; B, group centroids. Stress $=0.09$. Circle-size indicates the third dimension.

Table 5 Proportion of samples in each sub-region belonging to different water chemistry groups. Cells are shaded grey if $\geq 20 \%$, or dark grey if $\geq 50 \%$, of samples from a sub-region belong to a water chemistry group.

\begin{tabular}{|c|c|c|c|c|c|c|c|c|c|}
\hline & WG1 & WG2 & WG3 & WG4 & WG5 & WG7 & WG8 & WG9 & WG10 \\
\hline Ashburton Lower & 0.06 & 0.19 & 0.03 & 0.37 & - & 0.10 & 0.06 & 0.02 & 0.16 \\
\hline Fortescue Lower & 0.04 & 0.25 & 0.01 & 0.43 & - & - & 0.03 & - & 0.22 \\
\hline PHC Lower & - & 0.18 & 0.06 & 0.22 & - & 0.03 & 0.02 & - & 0.49 \\
\hline De Grey Lower & 0.02 & 0.31 & 0.03 & 0.42 & - & 0.12 & 0.03 & - & 0.08 \\
\hline Ashburton Middle & 0.06 & 0.20 & - & 0.27 & - & 0.11 & - & 0.01 & 0.36 \\
\hline Fortescue Middle & 0.03 & 0.15 & 0.06 & 0.21 & 0.01 & 0.03 & 0.01 & - & 0.50 \\
\hline De Grey Middle & - & 0.09 & - & 0.32 & 0.01 & 0.22 & 0.06 & - & 0.29 \\
\hline Ashburton Upper & 0.02 & 0.29 & 0.02 & 0.26 & 0.08 & - & 0.02 & 0.03 & 0.26 \\
\hline Fortescue Upper & 0.03 & 0.21 & 0.01 & 0.21 & 0.01 & 0.01 & 0.08 & - & 0.43 \\
\hline PHC Upper & - & 0.15 & - & 0.16 & - & 0.37 & - & 0.03 & 0.28 \\
\hline De Grey Upper & - & 0.31 & - & 0.23 & 0.06 & 0.05 & 0.14 & - & 0.20 \\
\hline
\end{tabular}


A

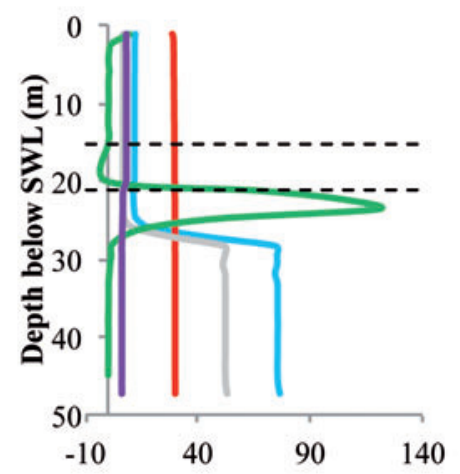

D

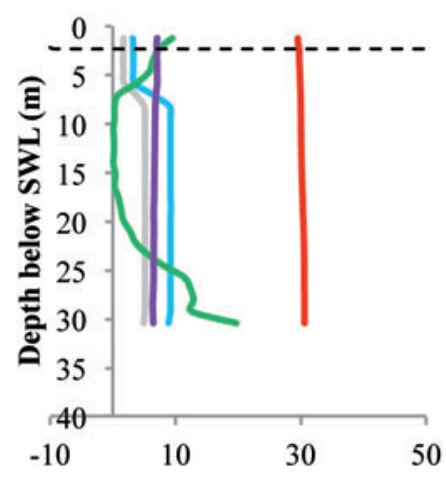

G

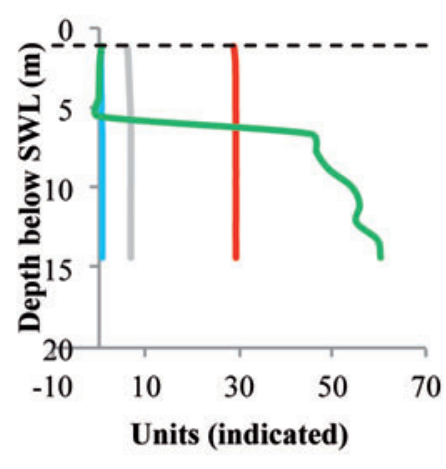

(indicated)
B

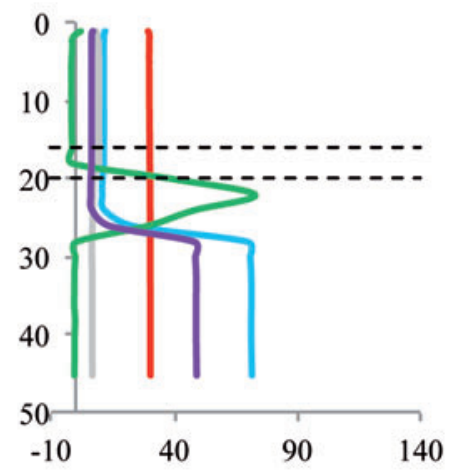

$\mathbf{E}$

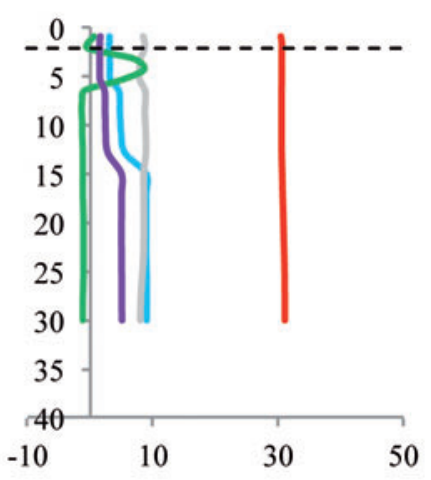

$\mathbf{H}$

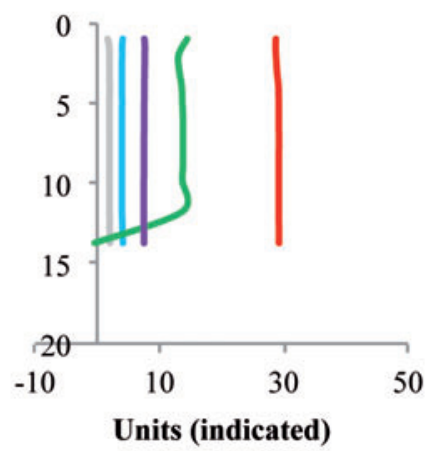

$\longrightarrow$ Temp (C) $\quad-$ SAL (ppt)
C

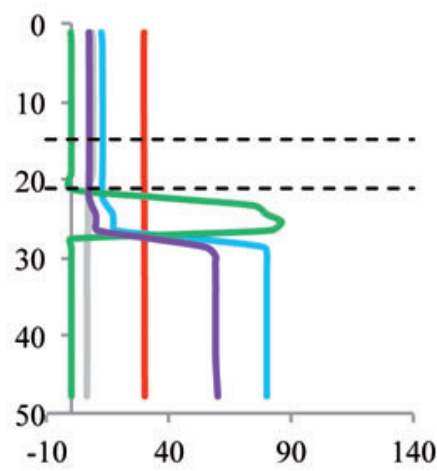

$\mathbf{F}$

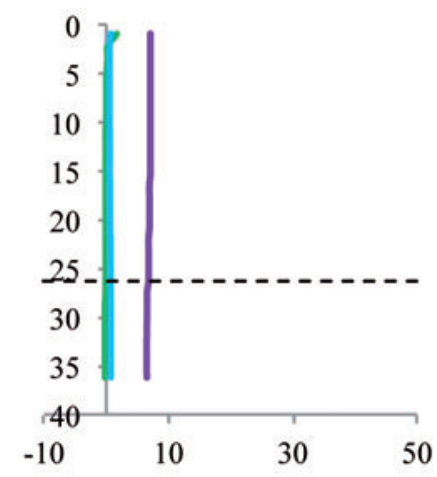

I

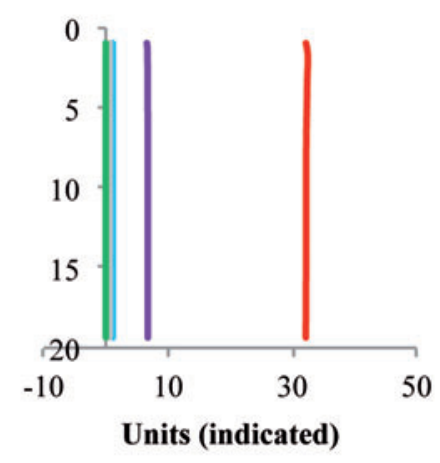

$-\mathrm{DO}(\%) \quad-\mathrm{pH}$

Figure 5 Physico-chemical profiles of selected wells. Wells slotted at dashed depths (slotting data not always available). A, Cowra T243 13.vi.2005; B, Cowra T243 27.ix.2005; C, Cowra T243 29.vii.2006; D, Gidgi T274B 12.vi.2005; E, Gidgi T274B 27.ix.2005; F, Weeli Wolli BH15 11.v.2005; G, Mindi T359B 12.vi.2005; H, NWSLK220B 25.ix.2005; I, MBSLK356A 25.vii.2006. 
Despite the range of water chemistries (Appendix 2), $79 \%$ of samples in the Pilbara belonged to the groups WG2 (weakly saline, $\mathrm{NaCl}$ dominated), WG4 (fresh, $\mathrm{Na}^{+}$dominant; $\mathrm{Cl}^{-}-\mathrm{HCO}_{3}^{-}$equivalent) and WG10 (very fresh, $\mathrm{Na}^{+}-\mathrm{Mg}^{2+}-\mathrm{Ca}^{2+}$ equivalent; $\mathrm{HCO}_{3}^{-}$ dominant), with another $9 \%$ of samples belonging to WG7 (fresh, $\mathrm{NaHCO}_{3}$ dominated) (Table 5). All groups other than WG6 had widespread occurrence but there was a tendency for samples from the middle and upper Fortescue and lower Port Hedland Coast catchments to belong to WG10, while the lower Ashburton, Fortescue and De Grey catchments had a high proportion of more $\mathrm{Na}^{+}$-dominated samples (WG4 and WG2). The upper Port Hedland Coast predominantly contained samples in the WG7 and WG10 groups. Water samples outside the Pilbara mostly belonged to WG2 and WG4, with the wells in the Great Sandy Desert almost all belonging to WG2.

\section{Groundwater profiles and purged bores}

Profiling showed little change with depth in most physico-chemical parameters in the wells profiled (Figure 5F, I), except around Fortescue Marsh where a lens of relatively fresh water overlaid more saline water at depth (Figure 5A-E). Dissolved oxygen was the most variable parameter, and measurements 1 $\mathrm{m}$ below SWL did not predict DO concentrations in the remainder of the water column for $34 \%$ of wells and were only marginally accurate for a further $7 \%$. In some wells DO concentrations increased in the slotted section of the well, perhaps implying that water above and below the slots was stagnant and depleted of oxygen (Figure 5A-C); whereas in other wells DO concentrations either increased or declined with depth (e.g. Figure 5G), perhaps reflecting concentrations in different aquifers. Profiles appeared to be temporally stable, and wells around Fortescue Marsh that were profiled in 2005 and 2006 showed similar profiles across seasons in 2005 and between 2005 and 2006 (Figure 5A-E).

Further evidence that water samples usually reflected conditions in the local aquifer, with the possible exception of DO, was provided by the results of purging six wells. Pre- and post-purging measurements of salinity, $\mathrm{pH}$ and ionic composition showed almost no differences from a faunal perspective (Figure 6). One of the purged wells was profiled prior to purging (Fortescue 32A) and the sample $1 \mathrm{~m}$ below SWL was representative of water column concentrations of all parameters other than $\mathrm{DO}$ in the bottom 3-4 $\mathrm{m}$ of the column.

\section{Characteristics of Pilbara stygofauna}

At least 350 recognisable species or morphospecies of stygofauna were collected during the survey (Plate 1, Appendix 3), with 314 of these collected from the 973 samples on which most analyses were based. The additional 36 species were collected in extra sampling associated with studies of sampling efficiency (Eberhard et al. 2009) or targeted sampling. Another 10 or so described species are known to occur in the Pilbara but were not re-collected during the survey.

Sixteen broad groups of stygofauna were collected, representing at least 43 families. Among the 350 species, ostracods were the most speciose group, followed by copepods (Figure 7A). Ostracods, copepods, amphipods and oligochaetes comprised about $77 \%$ of species, with many species of nematodes, water mites, isopods and syncarids also recognised despite the lack of taxonomic work in these groups (Appendix 3). A more exaggerated pattern of ostracod and copepod dominance was observed when animal abundance was examined using the dataset of 314 species, which represented occurrence patterns better because sampling effort was more even among wells (Figure 7B). Ostracods, copepods, amphipods and oligochaetes comprised more than $96 \%$ of all animals collected.

Using the dataset for the 314 species, it appears that community composition varied considerably across sub-regions (Figure 8), with ostracods comprising more than three-quarters of the fauna in all De Grey sub-regions, about half in
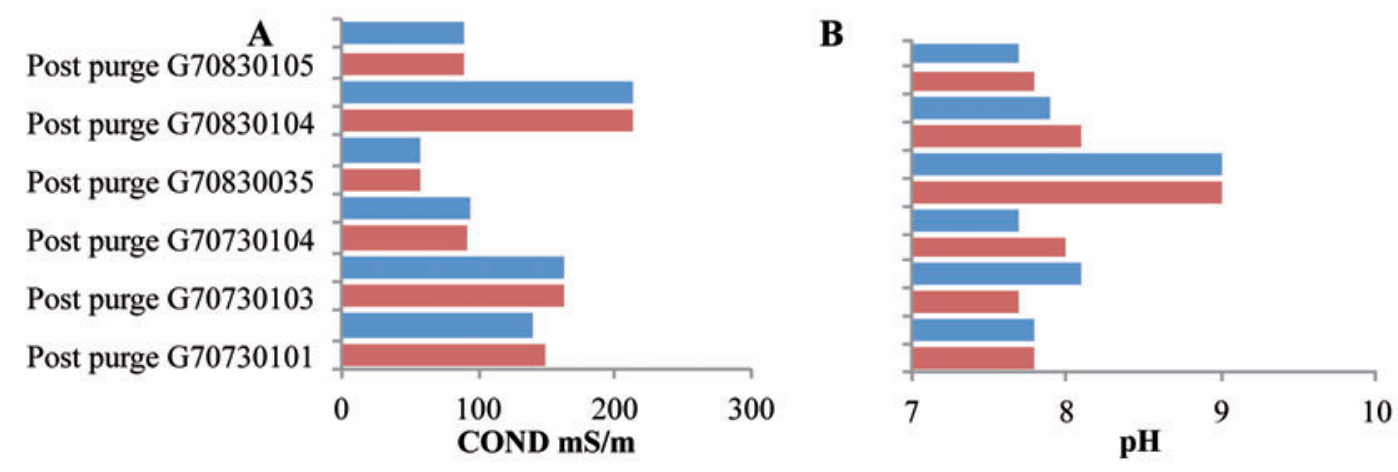

Figure 6 Measured salinity (mg L-1 TDS) and $\mathrm{pH}$ of selected wells before and after purging. Blue, before; red, after. 


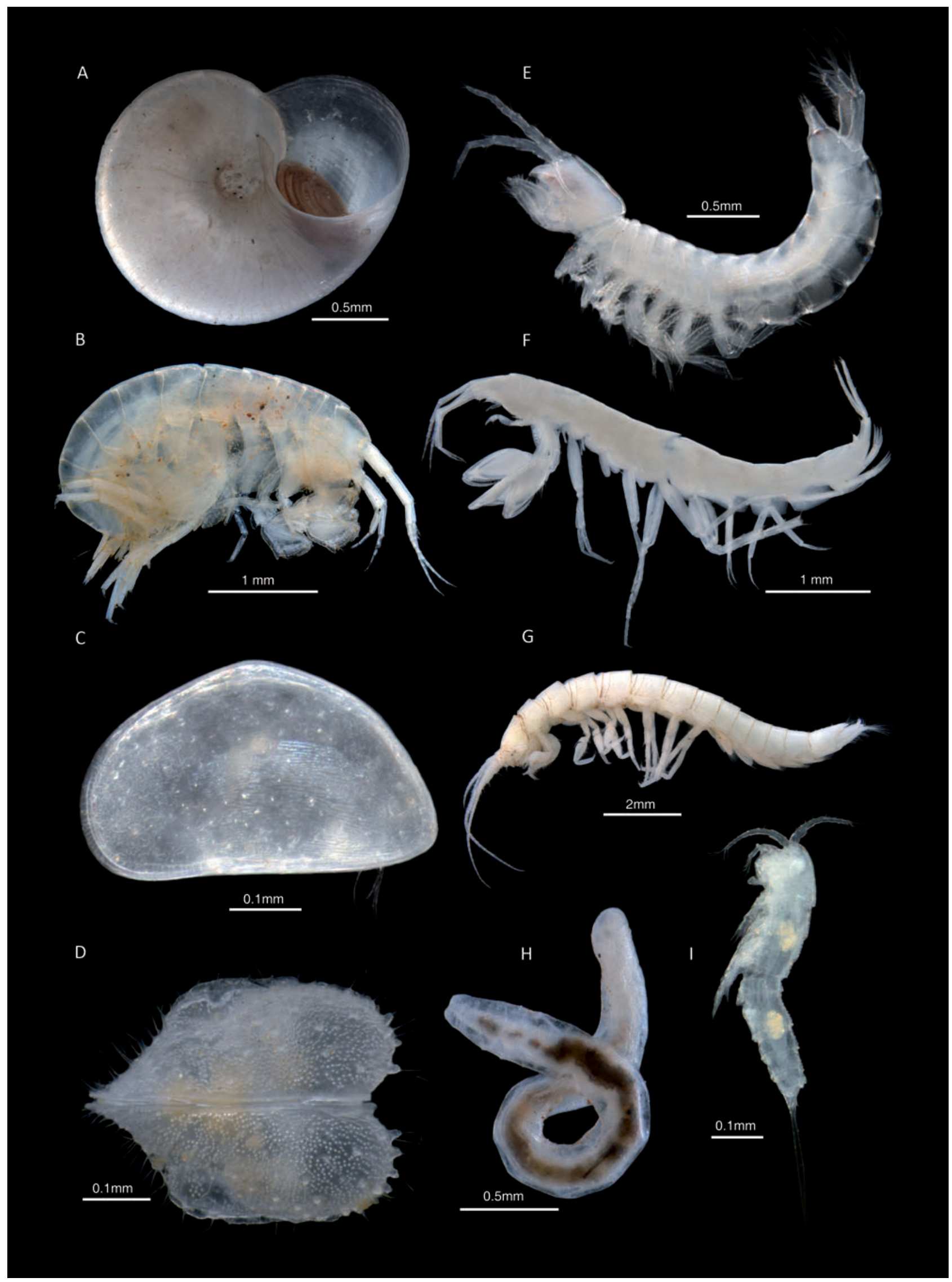

Plate 1 Stygofauna A, snail, Hydrobiidae; B, amphipod, Neoniphargidae; C, ostracod, Pilbaracandona rhabdote; D, ostracod, Gomphodella yandi; E, syncarid, Billibathynella; F, amphipod, Bogidiellidae; G, isopod, Pygolabis humphreysi; H, oligochaete, Enchytraeiidae; I, copepod, Elaphoidella humphreysi. 
A

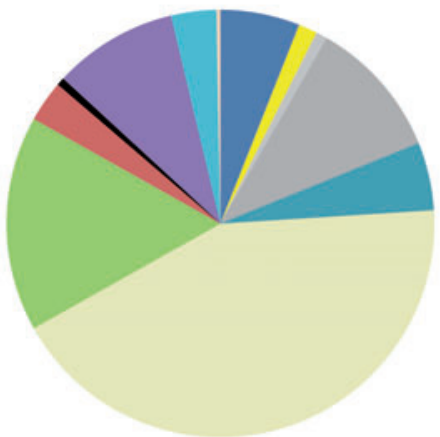

B

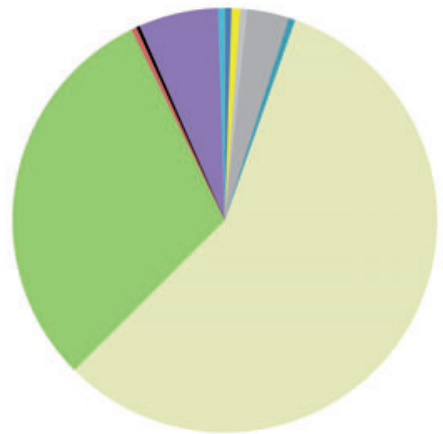

- Primitive worms

Rotifers

Molluscs

Worms

- Mites

Ostracods

= Copepods

Syncarids

- Other

- Amphipods

Isopods

Decapods

Figure 7 Taxonomic composition of Pilbara stygofauna. A, Number of species; B, Number of animals.
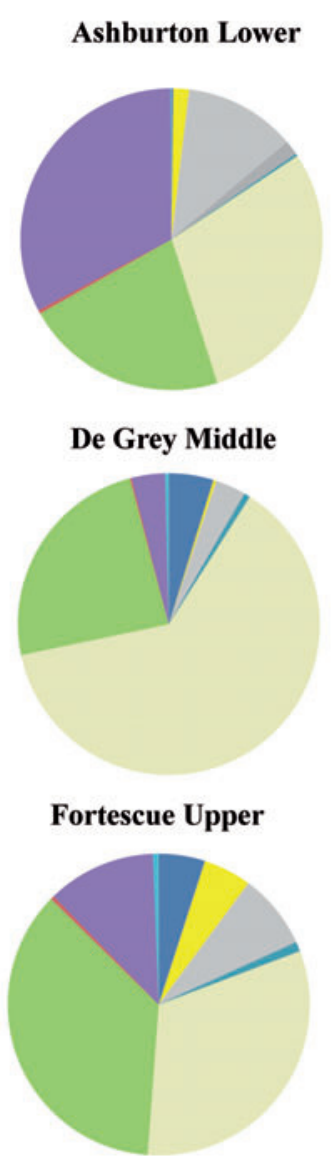

Eighty-mile Beach

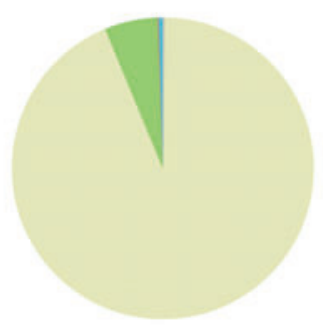

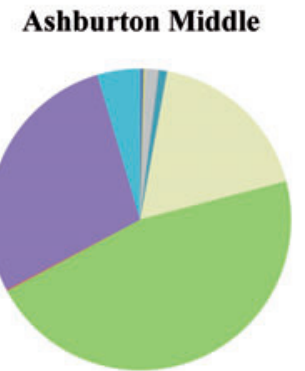

De Grey Upper

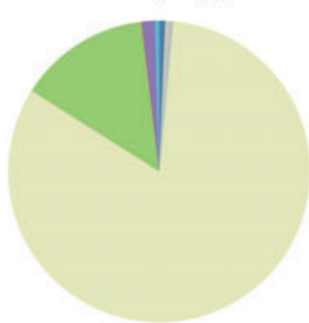

PHC Lower

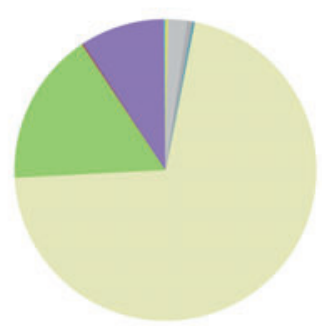

Sandy Desert

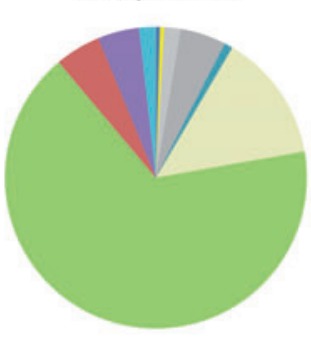

Ashburton Upper

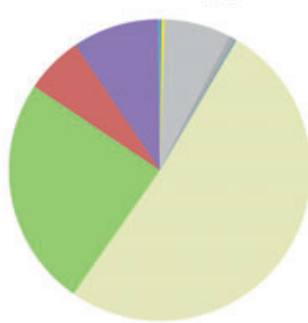

Fortescue Lower

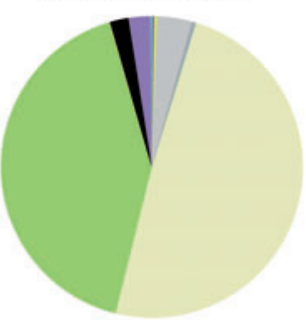

PHC Upper

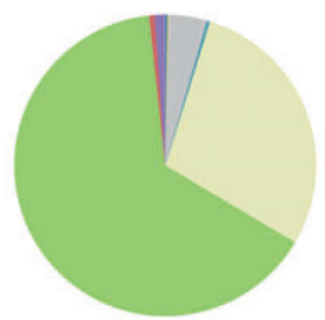

Yilgarn

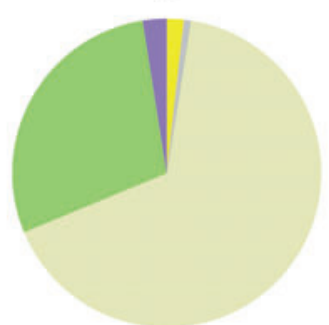

\section{De Grey Lower}

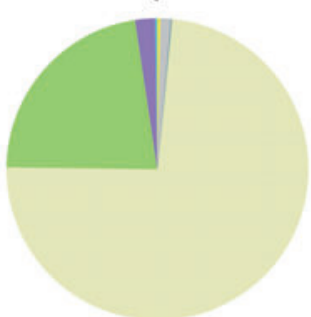

Fortescue Middle

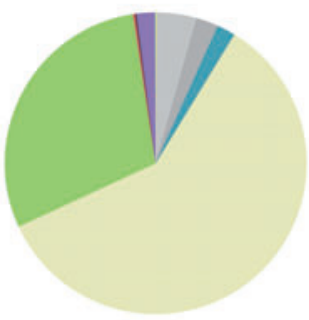

Carnarvon

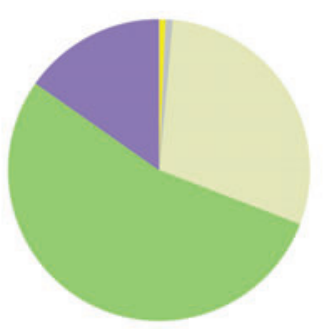

- Rotifers

Primitive worms

"Worms

"Molluses

-Mites

Ostracods

"Copepods

- Syncarids

- Other

- Amphipods

"Isopods

Decapods

Figure 8 Taxonomic composition of stygofauna in sub-regions of the Pilbara and elsewhere (Carnarvon, Eighty Mile Beach, Great Sandy Desert and north-east Gascoyne). 

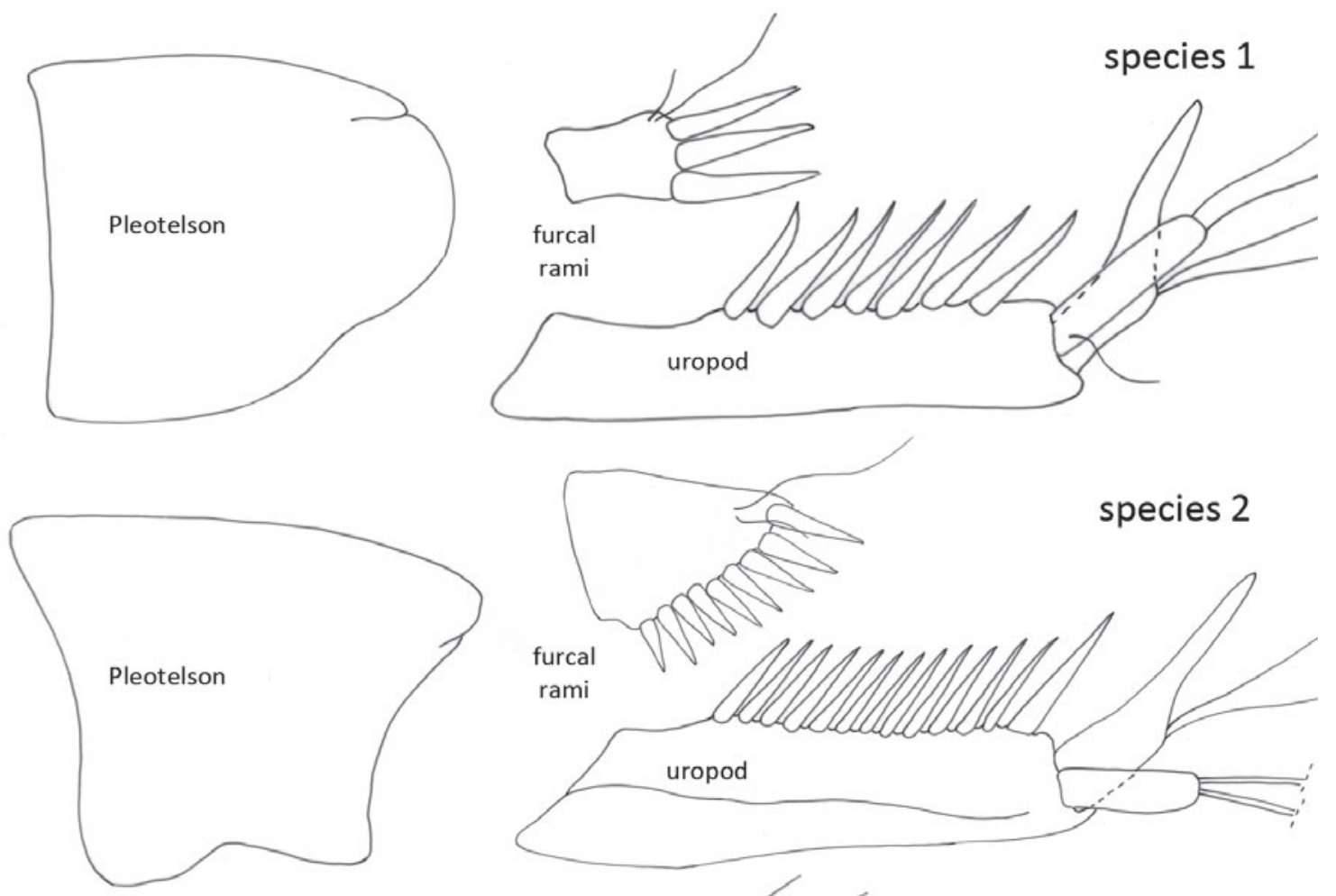

species 2
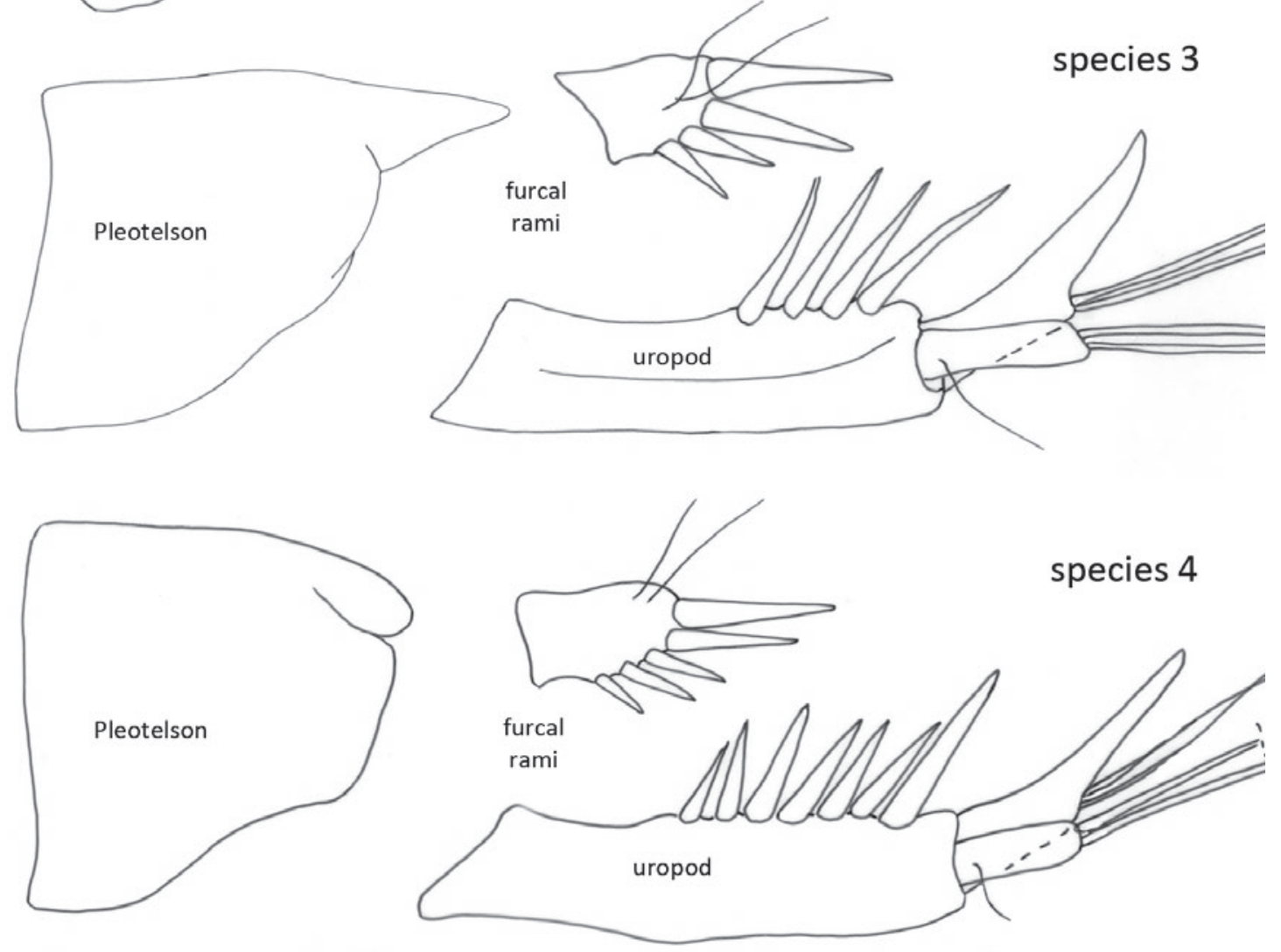

Figure 9 Pleotelsons, furcal rami and uropods of four possible species within Atopobathynella. 
the Fortescue sub-regions (although with fewer animals inland), and about one-third in the Ashburton and Port Hedland Coastal (with more animals in the inland Ashburton). Copepods varied from about one-quarter to more than half the fauna in different sub-regions without an obvious pattern to the distribution. The proportion of amphipods was greatest in the lower and middle Ashburton sub-regions, where the group comprised about onethird of the fauna. The lower Ashburton sub-region was comparatively rich in oligochaetes.

Assignment to the different categories of dependence on groundwater was attempted for 290 species (the others were mostly identifications at higher taxonomic levels for which no reasonable prediction about groundwater dependence could be made). About $83 \%$ of species were considered likely to be stygobites, 10\% stygophiles and 7\% stygoxenes.

\section{Taxonomic limitations}

The 314 stygofauna species used in analyses included 136 formally named species and 153 informally recognised morphospecies, as well as 25 higher-level identifications (genus or above) that were treated as single species in analyses. Another 11 described species, 33 morphospecies and 10 higher-level identifications were recognised in the dataset of 350 species.

The higher-level identifications include some groups where more species are known, or are likely, to exist. Darwinulid ostracods were identified only to family level but subsequent work showed that four species occur in the Pilbara (Schon et al. 2010). Syncarids were mostly identified only to genus but genera have been shown to consist of multiple species in the Kimberley and Yilgarn (Cho et al. 2005; Guzik et al. 2008) and this is also the case in the Pilbara. The four species of Atopobathynella illustrated in Figure 9 were not distinguished during the survey, despite possessing some distinctive characters, because of the poorly developed state of syncarid taxonomy in Western Australia at the time when survey samples were processed.

Discrepancies between survey identifications and species boundaries were perhaps greatest for amphipods. Genetic work has shown that the paramelitid amphipod genera Chydaekata and Pilbarus contain more species than recognised morphologically during the survey (Finston et al. 2007). Probably the number of amphipod lineages and, most certainly, the numbers of species within each lineage were underestimated during the survey, so that overall richness of amphipods was substantially underestimated. For example, recent unpublished morphological and genetic work has shown that the lineage identified as Paramelitidae sp. 2 (PSS) during the survey is a complex of at least eight species, including three species in the Weeli Wolli Creek catchment (Figure 10).

\section{Sample richness and abundance}

Stygofauna were collected in $72 \%$ of samples. The average sample (including those without stygofauna) contained $3.2 \pm 0.1$ species and 16\% of samples yielded $\geq 6$ species of stygofauna. The average number of animals per sample was $48 \pm$ 5.3. There was a significant relationship between the number of animals collected and the number

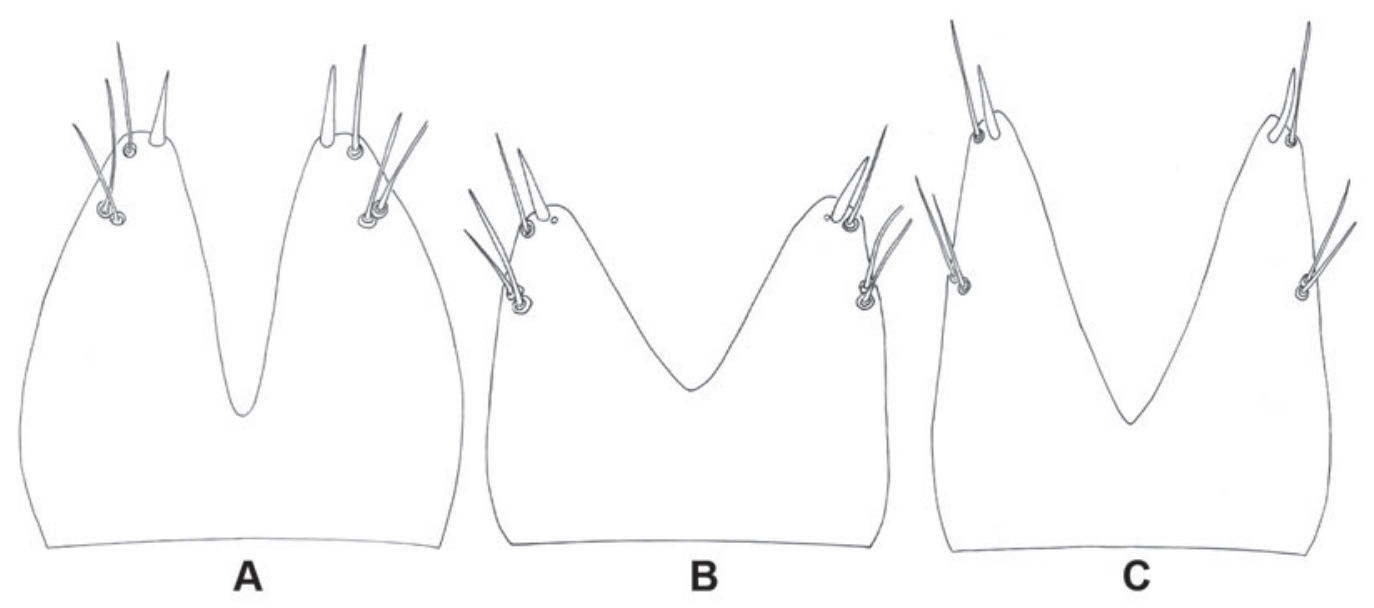

Figure 10 Some telsons of different species within the Paramelitidae sp. 2 (PSS) lineage from the Weeli Wolli Creek catchment. A, Paramelitidae genus 2 species 2; B, Paramelitidae genus 2 species 1; C, Paramelitidae genus 2 species 3 . 
of species present, but this relationship was driven by the constraining influence of small numbers of animals on the number of species present, and species yield did not increase substantially at animal abundances $>100$ (Figure 11).

The average number of species per sample varied geographically, although differences were relatively small in most cases (maximum factor of 2.5), with Tukey's HSD tests showing that downstream sub-regions tended to have higher richness than headwater sub-regions in the northern Pilbara (Figure 12). However, richness was variable within all sub-regions and the richness of individual samples showed overlap between most sub-regions.
The differences between Pilbara and adjacent subregions were of similar magnitude to differences within the Pilbara.

\section{Identification of communities}

Ten groups of samples were recognised in a classification based on order level composition of the animals in two samples from each well (Figure 13, Table 6). There was very little biogeographic signal in the classification, with the largest classification group (SG2) being the most common in all sub-regions (28-61\% of samples) and the next largest groups also occurring in all subregions (SG4 3-23\%, SG10 2-21\% and SG9 3-17\%,

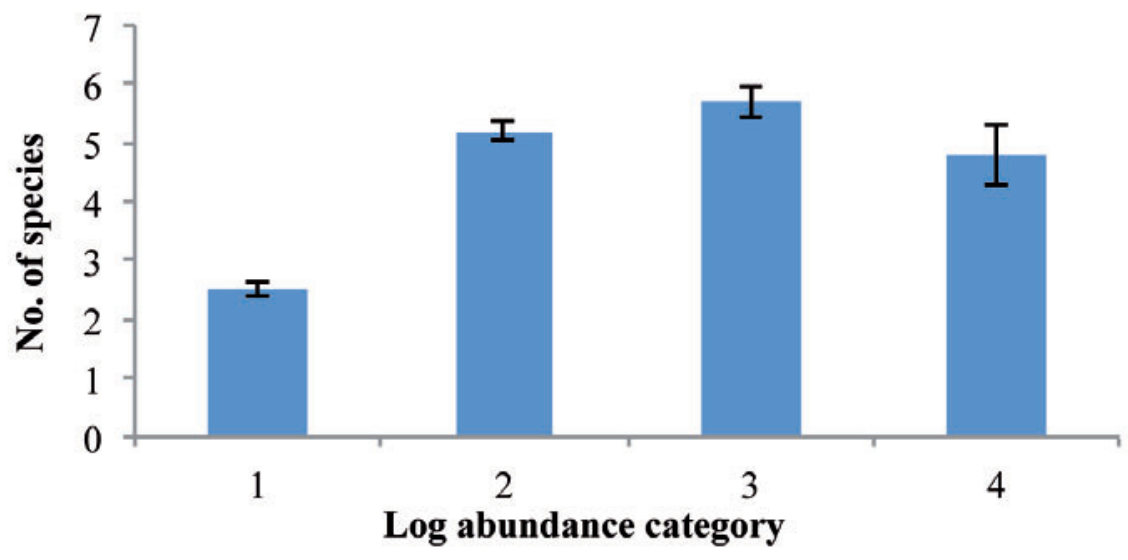

Figure 11 Mean $( \pm$ SE) number of species per sample according to log-scale sample abundance. Comparison between categories, $F=80, P<0.01$.

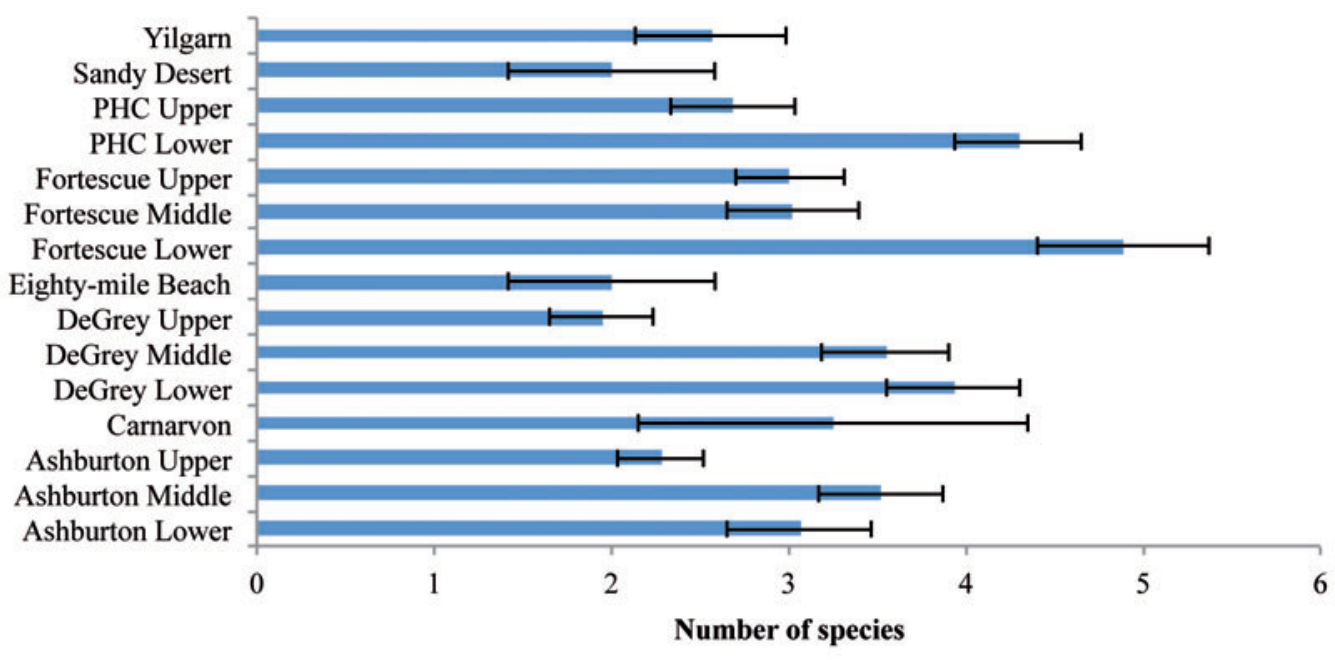

Figure 12 Mean $( \pm \mathrm{SE})$ number of species per sample for each sub-region. Comparison between sub-regions, $F=4.73$, $P<0.001$, untransformed data. 
Table 6 Characteristics of groups in the stygofauna classification. Where percentage composition is not stated, orders shown are represented at $100 \%$ of sites. Rich., average number of species in a well; Abund., average number of specimens.

\begin{tabular}{|c|c|c|c|c|c|c|}
\hline & $N$ & Rich. & Abund. & Dominant orders & TDS & $\mathrm{pH}$ \\
\hline SG1 & 18 & 2.6 & 7.1 & Amphipods $67 \%$, oligochaetes $47 \%$, isopods $32 \%$ & 0.8 & 6.9 \\
\hline SG2 & 226 & 6.6 & 83.4 & Copepods $86 \%$, ostracods $79 \%$, oligochaetes $59 \%$, amphipods $57 \%$ & 1.1 & 7.0 \\
\hline SG3 & 13 & 4.2 & 19.3 & Amphipods, copepods, oligochaetes & 0.8 & 6.9 \\
\hline SG4 & 65 & 6.0 & 96.8 & Amphipods $100 \%$, ostracods $100 \%$, copepods $85 \%$ & 1.1 & 7.0 \\
\hline SG5 & 21 & 2.8 & 37 & Ostracods, oligochaetes & 0.9 & 7.1 \\
\hline SG6 & 25 & 2.7 & 12.1 & Amphipods, copepods & 0.9 & 7.0 \\
\hline SG7 & 32 & 4.4 & 158.3 & Ostracods, copepods, oligochaetes & 1.3 & 7.1 \\
\hline SG8 & 37 & 6.2 & 76.5 & Amphipods, ostracods, copepods, oligochaetes & 1.5 & 6.9 \\
\hline SG9 & 49 & 2.8 & 81 & Ostracods, copepods & 1.2 & 7.1 \\
\hline SG10 & 59 & 5.0 & 89.5 & Amphipods, ostracods, copepods & 1.0 & 6.9 \\
\hline
\end{tabular}

respectively). The lack of biogeographic signal probably reflects that most stygofauna orders occur across the whole Pilbara and that site-specific factors have a greater role than geography in determining the richness and composition of the fauna at individual wells.

Most classification groups were dominated by ostracods (a dominant order in all but SG1, SG 3 and SG6, Table 6), copepods (all but SG1 and SG5) and amphipods (all but SG5, SG7 and SG9), which reflects the prevalence of these three orders in samples. The absence of ostracods from classification groups SG1, SG3 and SG6 reflects low $\mathrm{HCO}_{3}^{-}$concentrations, while their abundance in SG4 and SG5 reflects higher $\mathrm{HCO}_{3}^{-}$concentrations (Figure 13).

All classification groups other than SG2 occupied constrained areas of ordination space. SG2 contained $41 \%$ of all samples and contained the most speciose samples with diverse taxonomic composition, although SG7 samples contained almost twice as many animals on average and SG4 and SG10 samples contained $7-16 \%$ more animals than SG2 (Table 6). The very preliminary analyses conducted here suggest that, other than for ostracods, community structure is influenced less by water chemistry than by other habitat factors.

\section{Species distributions}

Sixty-nine per cent of the 154 stygofauna taxa collected at least twice, and representing named species or well-defined morphospecies, were collected from three or fewer sub-regions (Figure 14). This might be interpreted as indicating that the species are confined to a river basin or the catchment of a large tributary river (Figure 2). However, when the actual sub-regions occupied are examined, $79 \%$ of the species collected from two or three sub-regions were collected from more than one basin, which suggests that river basins and other surface hydrological features define the limit of a species range less well than previously thought. An alternative explanation is that many taxa recorded as species may be species complexes, with different species in different basins.

Somewhat surprisingly, given the expectation that many subterranean species will have tightly restricted distributions, only $23 \%$ of species recorded at least twice were collected from a single sub-region. The median range of those species that are actually restricted to a single sub-region was estimated using equation (1) as $682 \mathrm{~km}^{2}$. This calculation assumes that ranges are characteristic of a species rather than being determined by major physical constraints associated with subregional boundaries, such as catchment divides. The calculation highlights the likelihood of groundwater impacts extending over distances of $20-30 \mathrm{~km}$, such as may occur with large-scale mine dewatering, threatening the persistence of restricted species.

Documented species ranges, measured as number of sub-regions occupied, differed between various groups of stygofauna (Table 7 ). This 


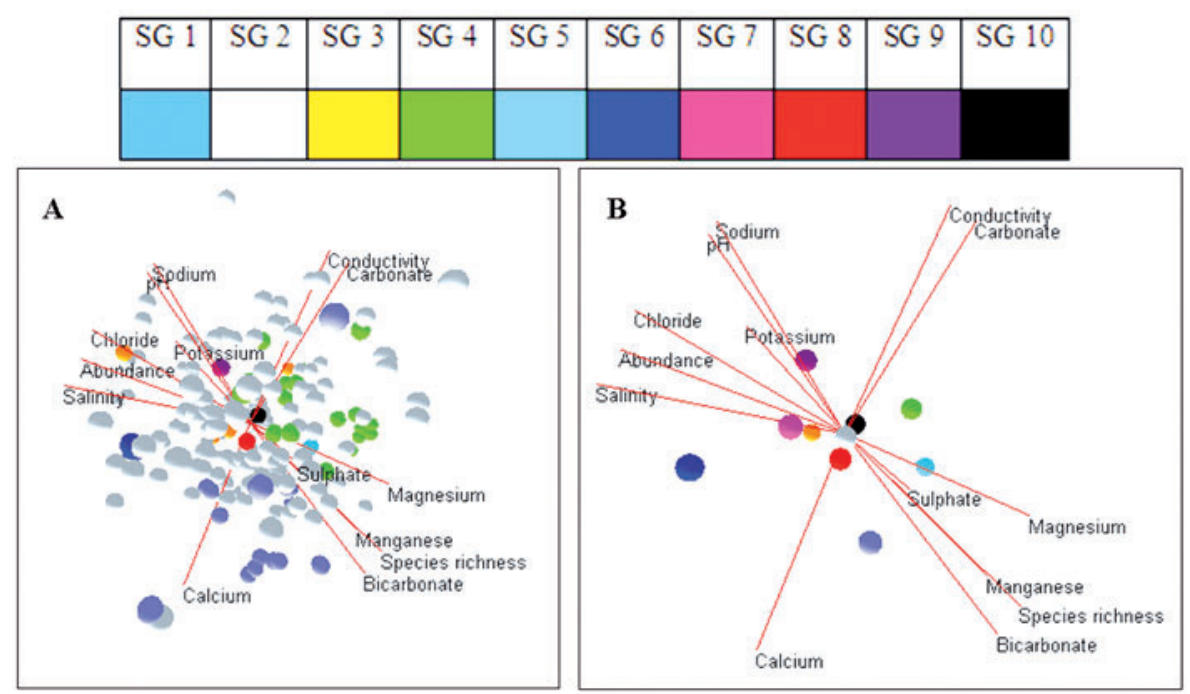

Figure 13 Three-dimensional SSH ordination of stygofauna samples based on order level analysis. Sites with no animals or only one order were removed from analysis, stress $=0.18$.

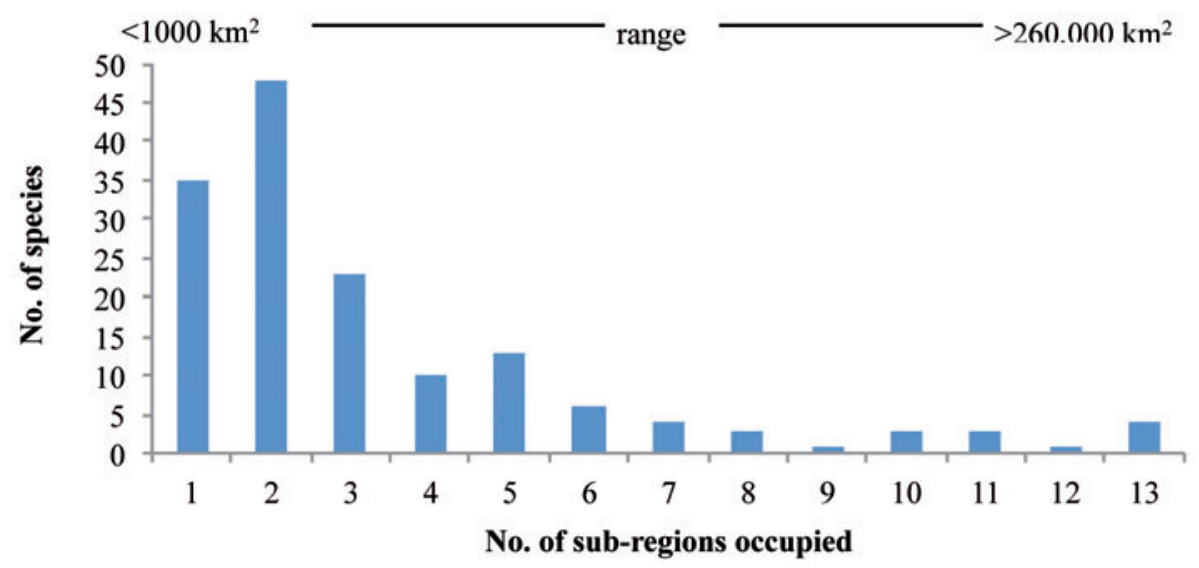

Figure 14 Number of species with ranges that occupy different numbers of sub-catchments.

reflected either variable patterns of distribution among groups or different approaches to species delineation (recognised species may have been more likely to consist of multiple taxa in some groups and species ranges in these groups were probably overestimated). The taxonomy of larger isopods and copepods is likely to be moderately robust and the larger isopod species occupied only one or two sub-regions, whereas copepods had a median range covering four sub-regions. There was, however, considerable variation between copepod species. The widespread stygobitic species included Stygoridgwayia trispinosa (11 sub-regions), Megastygonitocrella species ( $M$. trispinosa, $M$. bispinosa, M. unispinosa, 6-8), Elaphoidella humphreysi (9), Parastenocaris jane (7) and several Diacyclops species (D. humphreysi humphreysi, D. sobeprolatus, D. cockingi, D. scanloni, 13-8), Genetic analysis has excluded the possibility that occurrence of Diacyclops species across many sub-regions is the result of multiple cryptic species (Karanovic, T. and Krajicek 2012). Several species found widely 
Table 7 Median number and range of sub-catchments occupied by species in various groups of stygofauna. $N=$ number of species used in calculation .

\begin{tabular}{llll} 
& $N$ & Median & Range \\
\hline Aphaneura & 4 & 3.5 & $2-13$ \\
Oligochaeta & 20 & 3 & $1-10$ \\
Acarina & 7 & 2 & $1-5$ \\
Ostracoda & 62 & 2 & $1-10$ \\
Copepoda & 32 & 4 & $1-13$ \\
Syncarida & 1 & 2 & - \\
Thermosbaenacea & 1 & 3 & - \\
Amphipoda & 18 & 3 & $1-11$ \\
Isopoda & 9 & 1 & $1-2$ \\
\hline
\end{tabular}

in surface waters as well as groundwater were also collected from multiple sub-regions, including the cosmopolitan Microcyclops varicans (12) and Mesocyclops brooksi (13), which is widespread in southern Australia.

In contrast to the copepod pattern, stygobitic ostracod species were confined to single subregions, with the exceptions of Areacandona scanlonii (7 sub-regions) and Gomphodella hirsuta (5), whereas species also known from surface waters occurred in multiple sub-regions. Surface species included Candonopsis tenuis, which occurs throughout Australia with strong groundwater affinity (4 sub-regions), Cyprinotus kimberleyensis (6), Limnocythere stationis (8) and Cypretta seurati (10). The names of the latter two species, which are known from outside Australia, may have been applied incorrectly to Australian endemics but the important issue is that species also found in surface water have wide ranges compared with those species occurring only in deeper groundwater. It is likely that the widespread groundwater ostracod Gomphodella hirsuta consists of more than one species (in addition, contradictory distributions of Gomphodella species have contributed to confused identifications in the genus - see Karanovic, T. 2006, Karanovic, I. 2009).

Unlike larger isopods, the taxonomic framework used when identifying amphipods suggested that nearly all species had large ranges and were found in multiple sub-regions. Information collected subsequently has shown that this range information is misleading and is the result of the taxonomic framework for Pilbara amphipods being poorly developed when identifications were made.
Subsequent work has shown that most 'species' recognised in this paper in fact represent genera or species complexes. For example, Paramelidae sp. 2 (PSS) which was collected from 11 sub-regions consists of at least eight species, Melitidae sp. 1 (PSS) which was collected from 10 sub-regions consists of at least four species (King et al. 2012b), and Pilbara millsi which was collected from five sub-regions is probably a species complex (Finston et al. 2007). The work by Finston et al. $(2007,2011)$ suggests that amphipods are likely to be confined to single sub-regions.

Worms and mites were mostly widespread (Table 7). A high proportion of worm species are found in surface as well as groundwater, such as Pristina longiseta (10 sub-regions) and P. aquiseta (7). Stygofaunal mite taxonomy is not well developed but morphological examination and known life history information of the group (M.S. Harvey personal communication) suggest that most stygobitic mites in the Pilbara are moderately widespread.

\section{Factors affecting species occurrence}

Unsurprisingly, given the wide distribution of stygofauna communities across the Pilbara, few factors that affected sample yields strongly could be identified. The exception was well diameter; both species richness and animal abundance were greater in large wells than those with diameter $<750 \mathrm{~mm}$ (Figure 15, $P<0.001$ ANOVA and Tukey's HSD range tests). Casing had relatively little effect on the numbers of animals collected from wells although, in one of the two areas (Fortescue Lower and Middle sub-regions) where comparisons were 

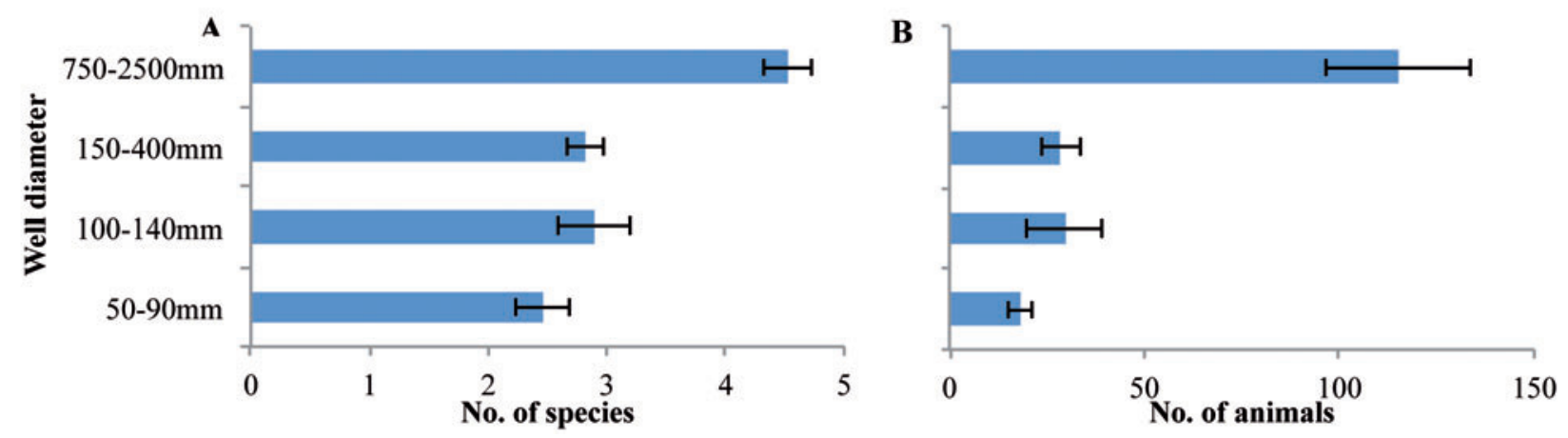

Figure 15 Mean number $( \pm \mathrm{SE})$ of species and animals collected in samples in relation to diameter of wells. Comparisons between diameters, $F=20.15, P<0.001$ for species and $F=56.70, P<0.001$ for abundance, abundance data log-transformed.
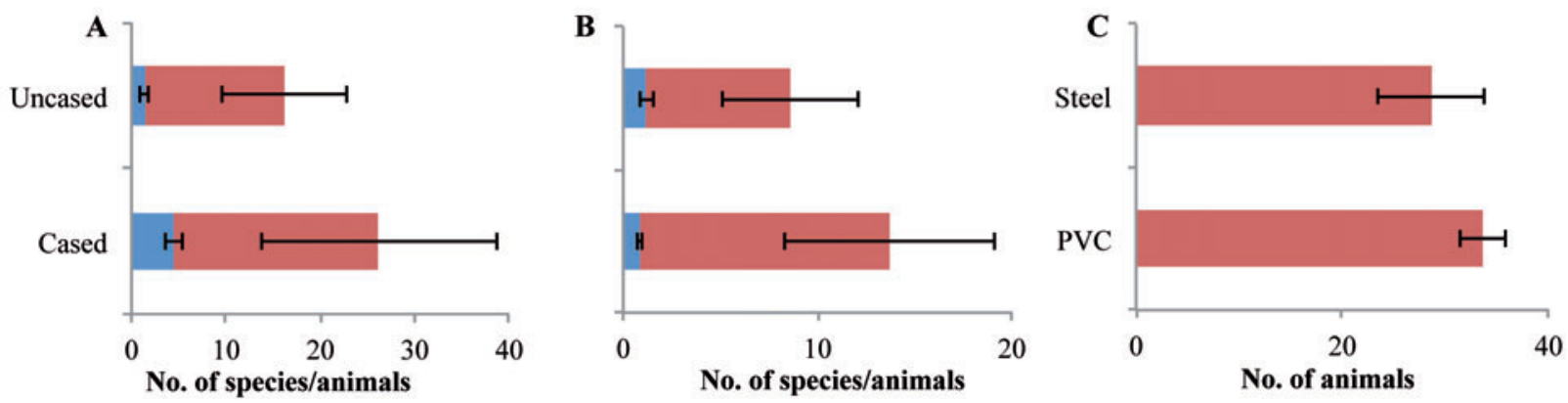

Figure 16 Mean $( \pm \mathrm{SE})$ numbers of species and animals collected according to well casing. Raw data plotted with number of species shown in left part of bar. Outliers were removed and number of animals logtransformed prior to statistical tests. A, Fortescue Lower $(t=3.19, P=0.003)$; B, Fortescue Middle; , all survey data $(t=2.64, P=0.008)$.

made, more species were collected from cased than uncased wells (Figure 16A, $t=3.19, P=0.003$ ). Among the cased wells, those with a PVC lining yielded about $50 \%$ more animals than steel casing (Figure $16 \mathrm{C}, t=2.64, P=0.008$ ). The reasons for this are not apparent. The standard slot sizes in PVC and steel casing are the same $(0.5$ or $1 \mathrm{~mm}$, with $1 \mathrm{~mm}$ used more in hard rock where no fine sediment is expected).

Depth to the water table was correlated negatively with both species richness and abundance in wells, although the relationships had very little explanatory power (7-9\%, Figure 17) and depth is better viewed as a constraint on the number of species and animals that may be collected rather than a predictor of these values. Large numbers of animals $(>50)$ were recorded only from depths less than $32 \mathrm{~m}$ and speciose samples ( $\geq 8$ species) only from depths less than $19 \mathrm{~m}$. Small numbers of animals were recorded from depths to groundwater of up to $88 \mathrm{~m}$, which was the maximum depth sampled.

Stygofauna occurrence was positively correlated with DO in the top metre of groundwater but the relationship had very little explanatory power for either species richness or abundance $(6-7 \%$, Figure 18). There was little variation in the maximum number of animals or species collected across the recorded range of DO (0-100\%) and the positive relationship was driven by more records of low animal and species numbers at very low DO rather than by higher numbers at high DO. Number of species collected was negatively correlated with salinity but there was no relationship for animal abundance (Figure 18). As with depth to the watertable, salinity appeared to constrain the 

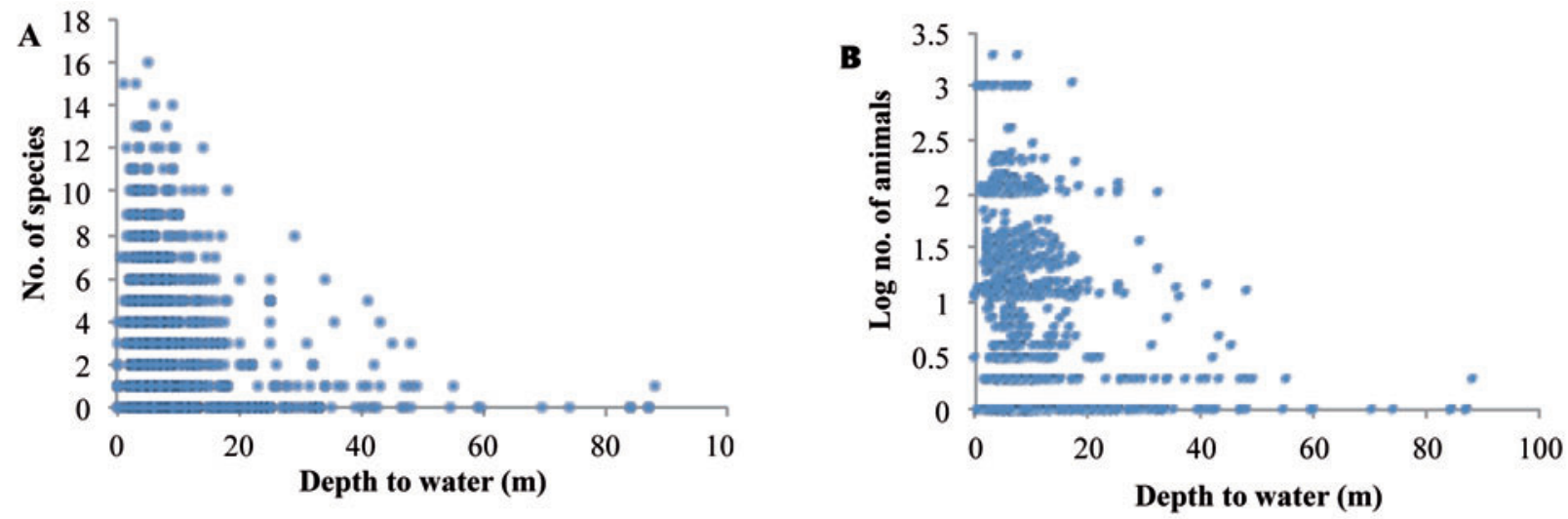

Figure 17 Relationship between stygofauna collected and depth to groundwater. A, number of species $(r=-0.31$, $P<0.001) ; \mathrm{B}, \log$-transformed number of animals $(r=-0.26, P<0.001)$.
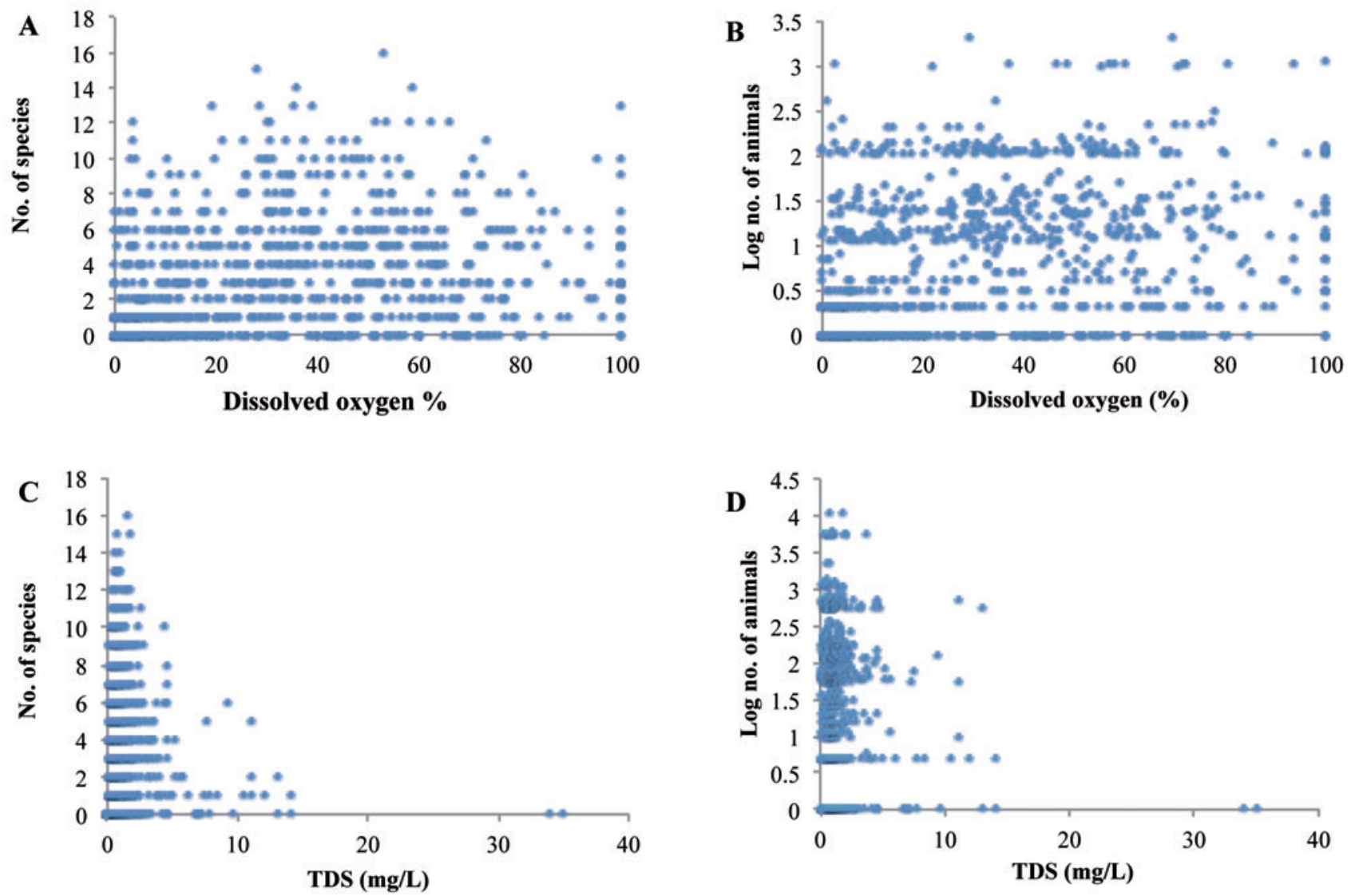

Figure 18 Relationship between stygofauna and percentage dissolved oxygen and salinity in top metre of water. A, number of species and DO $(r=0.24, P<0.001)$; B, log-transformed number of animals and DO $(r=0.27$, $P<0.001) ; C$, number of species and TDS $(r=-0.16, P<0.001)$; , log-transformed number of animals and TDS $(r=0.008$, NS). TDS values log-transformed for correlations. 
maximum number of species rather determine the actual number. No stygofauna were collected at salinities $>14 \mathrm{mg} / \mathrm{L}$ TDS (Figure 18) but this may merely reflect lack of samples from more saline areas. Distance to the coast explained little more than $1 \%$ of variation in richness and abundance, with numbers of animals and species declining somewhat $200 \mathrm{~km}$ and $400 \mathrm{~km}$, respectively, from the coast.

Geology, based on amalgamated 1:250,000 mapping units, influenced species richness and animal abundance less than expected. Numbers of animals collected were highly variable in aquifers of all geologies, although this variability was masked when applying standard errors to yields from Quaternary alluvials and Tertiary detritals by large sample sizes (Figure 19B). Sedimentary rock aquifers (mostly sandstone and dolomite), Quaternary alluvials, mafic volcanics (representing some lower altitude sites in the northern half of the Pilbara), granitic intrusives (representing greenstone areas of the northern Pilbara) yielded more animals than BIF or Tertiary detritals, although the overall statistical difference in animal yield between geologies was only marginally significant (driven by the low yield from Tertiary Detritals).

Surprisingly, aquifers in mafic volcanics supported more species than other geologies, although the average number of species per sample in mafic volcanics was little more than twice the number in the least prospective geologies (sedimentary rock and BIF) (Figure 19A). Some of the differences in species richness among the geologies may relate to the pattern of animal abundance but the high species yield from Tertiary detritals compared with number of animals present suggests species richness and animal abundance may behave differently.
Neither total $\mathrm{N}$ nor total $\mathrm{P}$ concentrations affected the numbers of stygofaunal species or animals collected ( $P>0.99$ in all cases).

\section{Temporal variation in yield}

While the number of species collected in the first and second samples from a well were correlated, slightly less than half of the variation in species richness of the second sample could be predicted from the first (Figure 20). At times the pairs of samples from a well showed large variations in yield, with differences of up to 11 species, but it was unusual for one sampling event to yield a large number of species if the other yielded none. Overall, there was no meaningful difference in average yield of the first and second samples (3.3 \pm 0.2 v. $3.4 \pm 0.2$ ). Wells sampled only once (excluded from this analysis) tended to have lower numbers of species.

Variations in the number of species collected from a well appeared to be largely stochastic. There was no overall difference between autumn and spring in the number of species collected per sample $(t=$ $-0.14,674 \mathrm{df}, P=0.89)$ and, while the mean richness per sample varied by about $30 \%$ across individual seasons, these differences were not significant (Table 8).

\section{Interpolation analysis}

Analyses of sub-regional patterns and the site characteristics that affect stygofauna occurrence indicate that stygofauna are distributed across the whole Pilbara, although approximately 19\% of wells yielded no stygofauna. The absence of stygofauna in samples from these wells may have been the result of local conditions being unsuitable for stygofauna, well construction being unsuitable for colonisation, or sampling error whereby the animals present in the well were not collected.
A

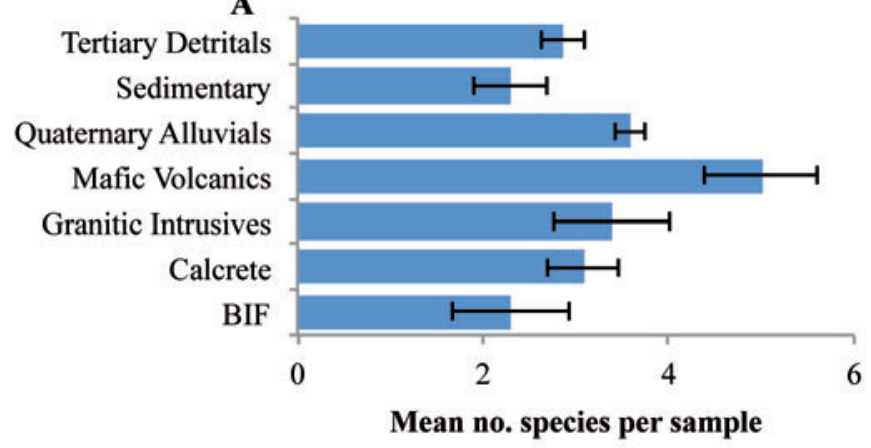

B

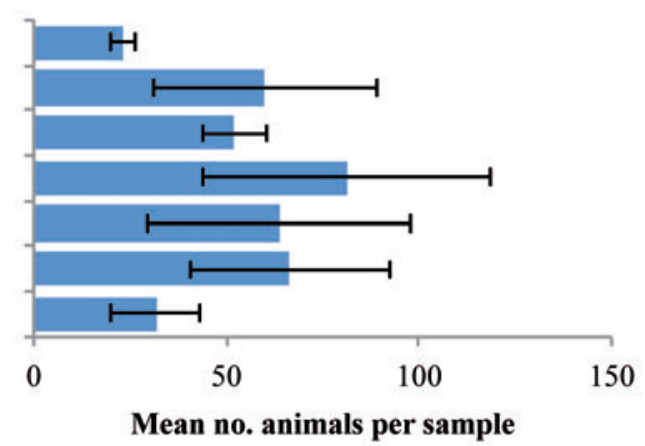

Figure 19 Mean number $( \pm \mathrm{SE})$ of species, and animals collected from samples in different geologies. A, number of species $(F=3.5, P<0.01)$; $\mathrm{B}$, number of animals $(F=2.08, P=0.05)$. 
Table 8 Mean number of species $( \pm$ SE) collected from samples each spring and autumn. $N=$ number of samples. Between all seasons comparison, $F=1.73, P>0.1$.

\begin{tabular}{lcc} 
Season & $N$ & Mean \\
\hline Spring 2002 & 60 & $3.6+0.4$ \\
Autumn 2003 & 132 & $3.5+0.3$ \\
Spring 2003 & 78 & $3.1+0.4$ \\
Autumn 2004 & 108 & $2.6+0.3$ \\
Spring 2004 & 125 & $3.3+0.3$ \\
Autumn 2005 & 127 & $3.7+0.3$ \\
Spring 2005 & 46 & $2.5+0.4$ \\
\hline
\end{tabular}

Fitting a kriged surface to species richness values of individual wells (based on the average richness of samples from the wells) indicated that pockets of high species richness occurred in all parts of the Pilbara except the south-east (Figure 21). There appeared to be six extensive areas of high stygofauna richness, namely: (1) southwards from the Robe River valley in the southern part of the Fortescue Lower sub-region along the boundary of the Ashburton Lower and Middle sub-regions; (2) around the Sherlock River on the boundary of the Port Hedland Coast Lower and Upper sub-regions, extending to the northern side of the Fortescue Middle sub-region; (3) around Paraburdoo at the eastern end of the Ashburton Middle sub-region; (4) around the Coongan River and De Grey Rivers north of Marble Bar in the eastern part of the De Grey Lower sub-region; (5) around the Strelley River in the western part of the De Grey sub-region; and (6) a less well developed area of richness in the headwaters of the Nullagine River in the De Grey Middle sub-region, with a nearby small area of richness in the northern Fortescue Upper subregion. There were a further three smaller areas of notable stygofauna richness: namely (7) the mouth of the Fortescue River in the Fortescue Lower subregion; (8) in Ethel Gorge near Newman in the Fortescue Upper sub-region; and (9) in the western Fortescue Plain near Millstream in the Fortescue Middle sub-region (Table 9, Figure 21).

Despite identification of the afore-mentioned areas of high stygofauna richness, kriging appeared to provide limited information about the occurrence of stygofauna beyond that obtained from direct sampling results. This was perhaps because kriging inferred intermediate richness values wherever sampling had not occurred. More regularly spaced sampling points would probably

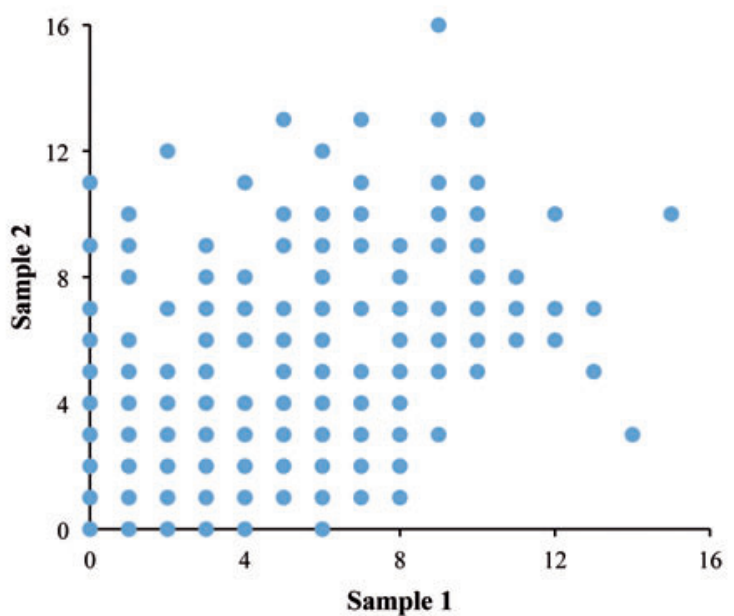

Figure 20 Relationship between number of stygofauna species collected in first and second samples from a well $(r=0.67)$.

have improved the capacity of kriging to infer true species richness in unsampled areas but logistical constraints (mostly the absence of suitable existing wells but also a requirement to obtain permission to access wells) prevented the selection of more regularly located wells as well as the alternative strategy of more randomly selected wells.

\section{Intensive sampling}

Intensive sampling within the Fortescue Lower sub-region, after the survey was completed, collected an additional 19 species that were not recorded in the area during the survey itself (a $42 \%$ increase in the fauna list, Table 10). A similar result was obtained from intensive sampling in 


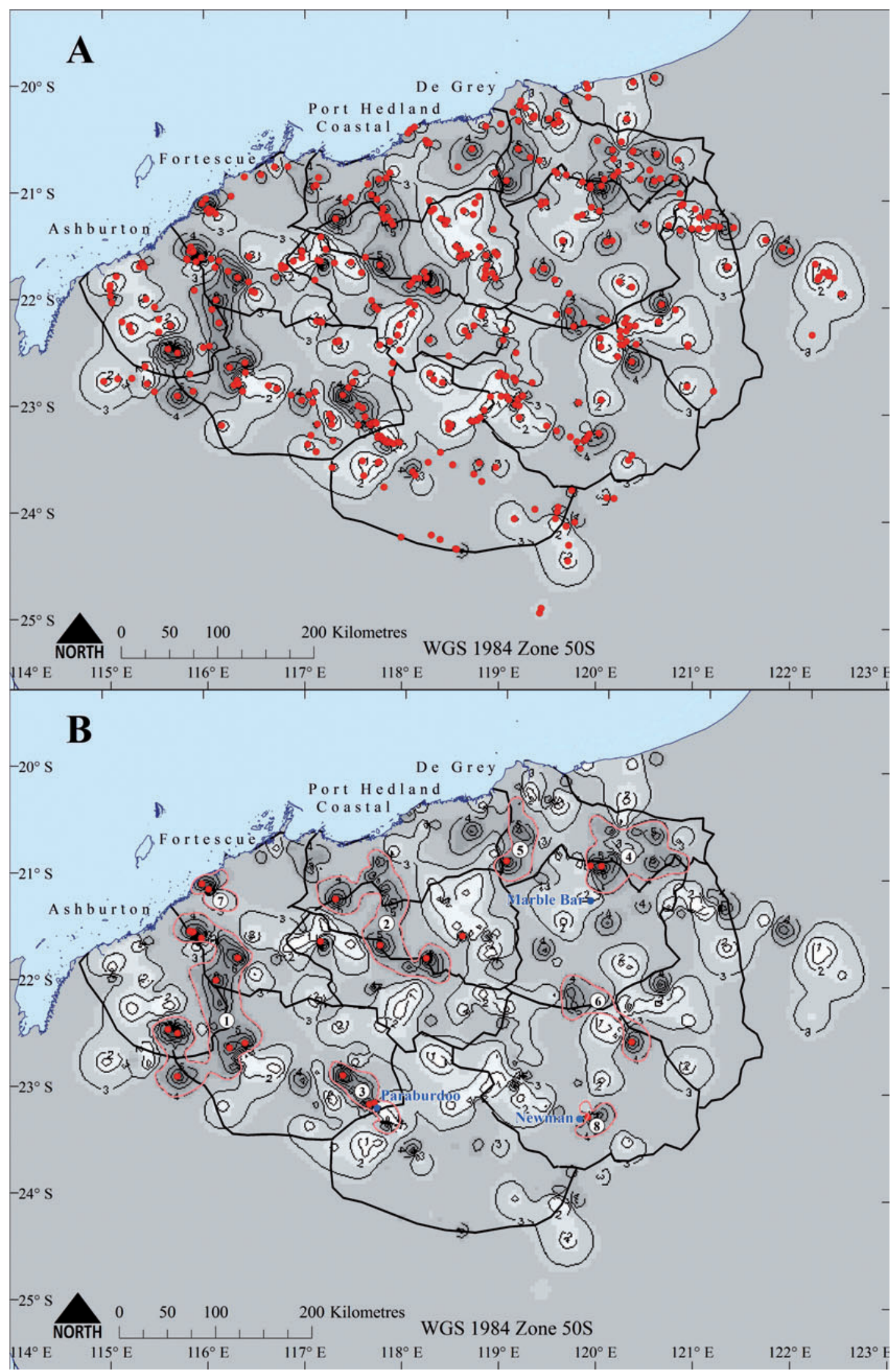

Figure 21 Interpolated species richness surface based on ordinary kriging. Number of species increases with density of shading. A, all bores sampled showing how there is little information about richness in unsampled areas, B, bores with $>9$ species per sample, areas of high stygofauna richness are numbered, see text for details of areas. 
Table 9 Nine areas of the Pilbara important for stygofauna.

\begin{tabular}{|c|c|c|c|}
\hline & Area & Description & Geology \\
\hline 1 & Robe Valley & $\begin{array}{l}\text { Most extensive area of high-yielding wells, associated } \\
\text { with Robe and Ashburton Rivers }\end{array}$ & Quaternary alluvials \\
\hline 2 & Sherlock River & $\begin{array}{l}\text { Area of high abundance from coastal plain to } \\
\text { headwaters of the Sherlock River, including some } \\
\text { George and Yule River wells }\end{array}$ & $\begin{array}{l}\text { Quaternary alluvials, } \\
\text { mafic volcanics }\end{array}$ \\
\hline 3 & Paraburdoo & $\begin{array}{l}\text { Discrete area of richness extending west from } \\
\text { Paraburdoo wellfield }\end{array}$ & Quaternary alluvials \\
\hline 4 & Coongan River & $\begin{array}{l}\text { Area of moderate richness between Coongan and De } \\
\text { Grey Rivers north of Marble Bar }\end{array}$ & Quaternary alluvials \\
\hline 5 & Strelley River & $\begin{array}{l}\text { Discrete area of moderate richness on the Strelley } \\
\text { River }\end{array}$ & Grantic intrusives \\
\hline 6 & Nullagine River & $\begin{array}{l}\text { Diffuse area of moderate richness in headwaters of } \\
\text { Nullagine near some areas where stygofauna appear } \\
\text { to be absent }\end{array}$ & Quaternary alluvials \\
\hline 7 & Fortescue Mouth & $\begin{array}{l}\text { Discrete area of high abundance associated with } \\
\text { Fortescue River mouth }\end{array}$ & Quaternary alluvials \\
\hline 8 & Ethel Gorge & $\begin{array}{l}\text { Discrete Threatened Ecological Community near } \\
\text { Newman }\end{array}$ & Quaternary alluvials \\
\hline 9 & Western Fortescue Plain & $\begin{array}{l}\text { Discrete area of high abundance on the Fortescue } \\
\text { River east of Millstream }\end{array}$ & $\begin{array}{l}\text { Calcrete, Quaternary } \\
\text { alluvials }\end{array}$ \\
\hline
\end{tabular}

the Fortescue Middle sub-region, where 24 extra species (33\%) were recorded.

Although in both sub-regions intensive sampling collected species not previously known from those sub-regions, the overall yields from intensive sampling were $18 \%$ and $26 \%$ lower than in the survey itself, despite sampling effort being about 2-2.4 times higher (Table 10). Sixteen species (36\% of the list) collected during survey in the Fortescue Lower sub-region and 34 species (44\%) in Fortescue
Middle were not recollected during intensive sampling. This was probably mostly a consequence of the intensive sampling covering smaller areas than the comparable units covered by the survey (see Figure 3). Species accumulation curves showed that, while the survey collected only $70-75 \%$ of the species known to occur in the two sub-regions, it accumulated species much faster than the two intensive sampling programs (Figure 22). The stratified sampling design used in the survey
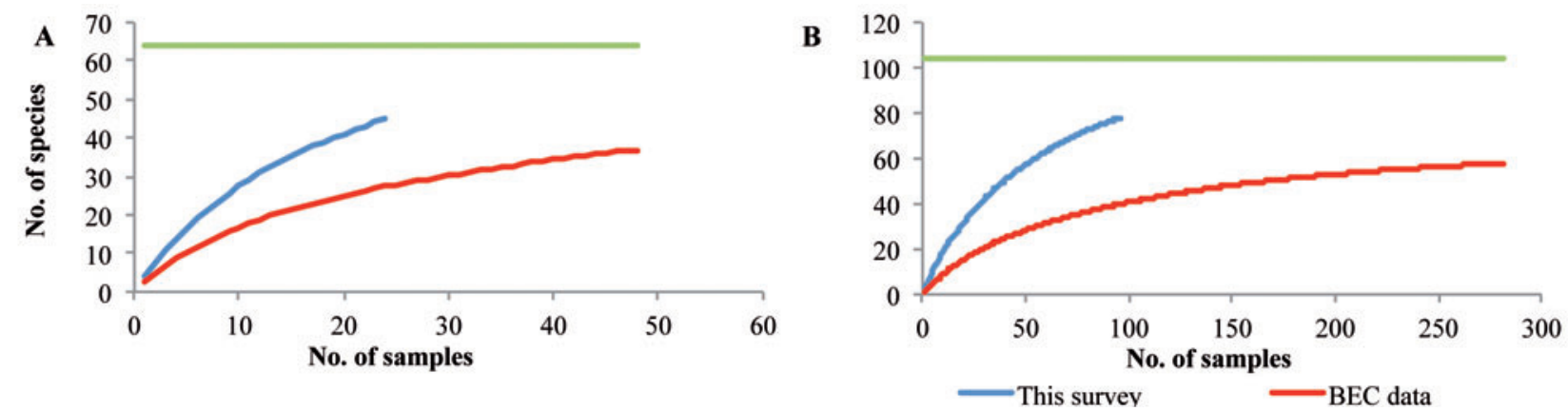

Figure 22 Mean number $( \pm \mathrm{SE})$ of species, and animals collected from samples in different geologies. Predicted species richness using ICE algorithm is shown. Bennelongia Environmental Consultants (BEC). A, Fortescue Lower; B, Fortescue Middle. Horizontal lines show number of species actually collected in each area from the combined sampling programs (Table 8). 
Table 10 Number of species collected during this survey and in subsequent intensive sampling by Bennelongia Environmental Consultants in the Fortescue Lower and Fortescue Middle sub-regions. Species recorded only during this survey are given as Not recollected, species recorded only by BEC are given as Extra to BEC. See Figure 14 for distribution of sampling in the two survey programs.

\begin{tabular}{lccccc} 
& Survey & BEC & Not recollected & Extra to BEC & Total \\
\hline Fortescue Lower & 45 & 37 & 16 & 19 & 64 \\
Fortescue Middle & 78 & 58 & 34 & 24 & 102 \\
\hline
\end{tabular}

Table 11 Numbers of stygofauna species in different regions of the world (modified from Gibert and Culver 2009).

\begin{tabular}{lcc} 
Region & No. of species & Area $\left.\mathbf{( k m}^{2}\right)$ \\
\hline Pilbara & 550 & 261,144 \\
Europe & 2000 & $10,180,000$ \\
Dinaric karst & 396 & 60,000 \\
France & 380 & 674,843 \\
Italy & 265 & 294,140 \\
Romania & 193 & 233,391 \\
Asia & 561 & $44,579,000$ \\
Japan & 210 & 377,944 \\
Africa & 335 & $30,221,532$ \\
North America & 500 & $24,709,000$ \\
USA & 300 & $9,826,675$ \\
South America & 100 & $17,840,000$ \\
\hline
\end{tabular}

provided more information about the composition of the sub-regional and regional fauna than would be obtained by combining the results of a series of intensive surveys of similar total sampling effort.

\section{DISCUSSION}

The collection of at least 350 recognisable species or morphospecies of stygofauna is a considerable underestimate of the richness of the Pilbara. Using the dataset reported here, Eberhard et al. (2009) calculated that between 500 and 550 species occur in the Pilbara, assuming that the taxonomy used was sound. The additional sampling undertaken in the Fortescue Lower and Middle sub-regions subsequently showed the survey under-collected species in these sub-regions by at least $42 \%$ and $33 \%$, respectively (Table 10). This coincides well with Eberhard et al.'s (2009) estimate of 500-550 species occurring in the Pilbara as a whole, which implied under-collection by up to $36 \%$.

The actual number of species in the Pilbara is likely to be substantially higher than 500-550 species (see Guzik et al. 2010) because, while the taxonomy used in the survey may have been reasonably sound for some groups, it was not for amphipods, syncarids, microcerberid isopods and molluscs. Nor was it sound for nematodes, bdelloid rotifers and other groups that are poorly known even in surface water systems. For amphipods, little effort was made to distinguish between the various melitid species and, although a framework was 
established for paramelitid taxonomy, the evidence from taxa such as Paramelitidae sp. 2 (PSS) is that an order of magnitude more species may exist than were recognised. The degree of taxonomic lumping was also high for syncarids; impact assessment reports have shown that numerous species of Bathynellidae occur in the Pilbara (e.g. Bennelongia 2012b), and the geographic distribution of survey records suggests that at least seven species were collected although only three were recognised. Among the Parabathynellidae, single species within the genera Billibathynella and Atopobathynella were recognised, although the geographic distribution of records suggests at least nine and five species, respectively, were collected. Recent work by Guzik et al. (2008) and Cook et al. (2012) suggests that most areas across Australia support multiple species of parabathynellid.

\section{Global significance of Pilbara fauna}

As explained above, we regard Eberhard et al.'s estimate of 500-550 stygofauna species in the Pilbara as too low but, even using the estimate of 550 species, the Pilbara is a globally important region for stygofauna in terms of the number of species present and, on the basis of current knowledge, it supports higher stygofauna species density than any region of the world other than the Dinaric karst in the Balkan Peninsula (6.6 species per $1,000 \mathrm{~km}^{2}$ in the Dinaric karst v. 2.1 in the Pilbara, Table 11). While global comparisons must be treated with some caution because much of Africa, Asia and South America is unstudied, Europe and North America are moderately well surveyed and provide a baseline against which the Pilbara has been assessed (e.g. Culver et al. 2003; Deharveng et al. 2009; Gibert and Culver 2009).

Just as the Dinaric karst represents the richest area of stygofauna species within the larger Balkan peninsula, which is rich in stygofauna as a whole (Sket et al. 2004), it has been estimated that the 3,500 $000 \mathrm{~km}^{2}$ western half of Australia actually supports 2680 species of stygofauna (Guzik et al. 2010). While most of these species remain to be discovered, the majority of them occur in the Pilbara or Yilgarn regions. The richness of the Yilgarn, to the south of the Pilbara, has been documented principally at the site level or in taxonomic studies (e.g. Watts and Humphreys 2006; Karanovic, T. and Cooper 2012). Early sampling showed that the Yilgarn supports at least 210 species (Humphreys 2008) and subsequent taxonomic work has shown that substantially more species are present (e.g. Cho and Humphreys 2010; Karanovic, T. 2010; King et al. 2012a). The Yilgarn may, in fact, have similar richness to the Pilbara. Most species in the Yilgarn occur in the calcrete aquifers of palaeodrainage valleys (Humphreys et al. 2009).
Stygofauna occur north of the Pilbara in the Kimberley region (e.g. Wilson and Ponder 1992; Karanovic, I. and Marmonier 2002; Cho et al. 2005; Susac et al. 2010) but, while there has been relatively little survey in the Kimberley and publications are mostly taxonomic, it appears to have a less well-developed fauna than the Pilbara and Yilgarn (Hancock and Bennison 2005; Bennelongia 2012c). Poorly developed stygofauna communities also occur in south-western Australia and the Nullarbor region. Groundwater of the Swan Coastal Plain and adjacent Darling Range in the south-west supports communities consisting mostly of syncarids and stygophilic copepods (e.g. Schmidt et al. 2007; Tang and Knott 2009; GHD 2010; Bennelongia 2009a). Various relatively small cave systems support limited stygofauna communities (e.g. Jasinska et al. 1996; Karanovic, I. 2003; Eberhard et al. 2005c; Moulds 2007). The cave systems of the Nullarbor support few stygofauna species despite their large size (Holmes et al. 2001) but some of the species present are scientifically interesting (Karanovic, $\mathrm{T}$. and Eberhard 2009).

Less is known about stygofauna communities elsewhere in mainland Australia, although a significant amount of work by researchers, especially at the South and Western Australian Museums, is currently underway and inventory surveys are being undertaken by industry as part of the environmental approval process (e.g. ALS 2012; Subterranean Ecology 2012a). Based on existing work, it appears that cave stygofauna communities in the Northern Territory are relatively depauperate (Moulds and Bannink 2012). Richer communities occur in calcrete aquifers of the Ngalia basin (Humphreys 2008) but there is little published evidence of widespread occurrence of stygofauna in other aquifers of the Northern Territory. Eastern parts of New South Wales and Queensland appear to support stygofauna communities of only moderate richness in alluvial aquifers (Hancock and Boulton 2008; Asmyhr and Cooper 2012; Cook et al. 2012), with about 40 species known from Queensland to date (ALS 2012) and slightly higher richness in New South Wales. Caves in New South Wales appear to have moderately diverse stygofauna communities, although in many cases identifications have not been to species level (Thurgate et al. 2001a, b).

In South Australia stygofauna communities have been found along the coast (Leijs et al. 2011) and in the Flinders Ranges (Leys et al. 2010; Abrams et al. 2013). There are also rich communities of groundwater-associated invertebrates in the springs of the Great Artesian Basin and some of these species are related to stygofauna in the Yilgarn (Murphy et al. 2009).

In their review of Australian stygofauna, Guzik 
et al. (2010) emphasised the importance of aridity as a factor leading to regional richness of stygofauna. Mostly on the basis of unpublished information, they suggested that arid parts of the Northern Territory and central Queensland may support numbers of stygofauna species similar to those in the Yilgarn region of Western Australia. Existing data on numbers of species, however, clearly differentiate the stygofauna communities of the Pilbara and Yilgarn from the rest of Australia, and most of the world, in terms of their species richness.

\section{Uniqueness of Pilbara fauna}

One of the major differences between stygofauna studies in the Pilbara and those in most other regions has been the way that Pilbara studies have highlighted the occurrence of stygofauna in groundwater throughout the landscape in shallow and deeper subterranean habitats (see Pipan and Culver 2012 for discussion of shallow subterranean habitats). Stygofauna have been recorded in nearly all parts of the Pilbara and the areas from which they appear to be absent are likely mostly to be sampling errors (Figure 20), whereas a recent European survey found stygofauna in only $26 \%$ of 4668 sampling units, each measuring $300-400 \mathrm{~km}^{2}$ (Deharveng et al. 2009).

Nearly all stygofauna species occurring in the Pilbara are endemic in the region. Of the 290 species for which range at the regional level could be determined, $98 \%$ of the stygobites and $83 \%$ of the other groundwater species (stygophiles and perhaps a few stygoxenes) are known only from the Pilbara, with no more than three stygobitic species having ranges extending outside the Pilbara. The calanoid copepod Stygoridgewayia trispinosa occurs on the Cape Range peninsula (Tang et al. 2008), the cyclopoid copepod Diacyclops humphreysi humphreysi occurs on Barrow Island and in south-western Australia (Karanovic, T. 2006) and the species of Stygiocaris on the Pilbara coast may be S. lancifera, which occurs on the Cape Range peninsula (a related species, S. stylifera, also occurs at Exmouth as well as on Barrow Island; Page et al. 2008).

In addition to the high level of endemism, the taxonomic composition of stygofauna in the Pilbara differs from most regions of the world because of the dominance of ostracods, which represent $41 \%$ of species in the Pilbara compared with an average 3\% in the rest of the world (Figure 7; Eberhard et al. 2005a). Copepods or a combination of copepods, isopods and amphipods dominate the stygofauna communities of most regions of the world (Deharveng et al. 2009). The ostracod richness of the Pilbara principally reflects an extraordinary radiation of the family Candonidae, with 86 described and many undescribed species (Karanovic, I. 2007; Karanovic, I. and McKay 2010).
Other regions of Australia have low proportions of ostracod species and very few candonids (Karanovic, I. 2003, 2005), although the genus Candonopsis has also radiated in the Yilgarn region (Karanovic, I and Marmonier 2002).

The other notable feature of the Pilbara is the near absence of stygofaunal beetles, which form an important component of the fauna of the Yilgarn, where more than 80 species are known (Watts and Humphreys 2009). Beetles also occur in the Ngalia Basin in the Northern Territory well to the east of the Pilbara and at lower numbers in New South Wales (Watts et al. 2007, 2008) and South Australia (Leys et al. 2010). No beetles were recorded during the survey and, despite a considerable amount of other sampling for environmental impact assessment, only one stygofaunal beetle species of the family Dytiscidae has been recorded in the Pilbara (Watts and McRae 2013).

Further unusual features of Pilbara styofauna are the low proportions of mollusc and mite species $(1 \%$ and $5 \%$, respectively, compared with world averages of $10 \%$ and $16 \%$ ). The low number of mites in the Pilbara is markedly different from the situation in alluvial communities of eastern Australia where mites account for $23 \%$ of species (Hancock and Boulton 2008) but molluscs appear to be scarce in most Australian stygofauna communities (e.g. $3 \%$ of the fauna, Hancock and Boulton 2008).

As already pointed out, the currently recognised proportions of amphipod and syncarid species ( $9 \%$ and $4 \%$, respectively) in the Pilbara are likely to be considerable underestimates because of the relatively cryptic morphological differentiation amongst species. The Pilbara probably supports at least the world average proportion of amphipods $(19 \%)$ and above the average proportion of syncarids ( $4 \%$ ). The proportion of syncarids in the surveyed areas of eastern Australia is relatively high (22\%, Hancock and Boulton 2008) and the group appears to be speciose throughout Australia, including in the Yilgarn (Guzik et al. 2008; Camacho and Hancock 2011; Abrams et al. 2012, 2013), especially in alluvial and colluvial aquifers.

The Pilbara supports close to the world average proportion of copepod species $(18 \%$, world average 17\%; Eberhard et al. 2005a). Sampling collected relatively large numbers of copepods per species, so that the group comprised nearly half of all stygofaunal animals (Figure 7B), which is the situation in most regions of the world (Galassi et al. 2009). The proportion of copepod species in eastern Australia appears to be similar (14\%) to the Pilbara, in contrast to the much richer copepod fauna of the Yilgarn that may comprise more than half the stygofauna species present (Bennelongia 2007; Karanovic, T. and Cooper 2011, 2012). 


\section{Factors affecting stygofauna yields}

In line with the notion that sampling efficiency is an important determinant of how much stygofauna is collected, characteristics of the wells sampled appeared to influence stygofauna yield more than factors related to the community in the surrounding groundwater. Well characteristics include age and diameter of the well, with yields being low in recently installed wells (Bennelongia $2009 b)$. Large diameter wells $(\geq 750 \mathrm{~mm})$ had the highest yields, while numbers of animals caught appeared to be uniform in wells between $50 \mathrm{~mm}$ and $400 \mathrm{~mm}$ diameter (Figure 15). Sampling of a small number of $25 \mathrm{~mm}$ wells in the eastern Pilbara after completion of the Pilbara Biodiversity Survey suggests that yields decline in very small wells for logistical reasons: nets are difficult to lower in small wells and a substantial pressure wave is created in front of the net on retrieval.

Analyses indicate that well casing has relatively little effect on yields of stygofauna (Figure 16), although cased wells are easier to sample because there are few obstructions to snag sampling equipment. The higher yields from wells cased with PVC rather than steel matches anecdotal observations reported by Hose and Lategan (2012).

It is often remarked that stygofauna yields show considerable temporal variation and that recharge events may affect yield (e.g. Hancock and Boulton 2008, 2009). Yields frequently varied between sampling events but there was no obvious pattern and it is considered that the temporal variability was largely a result of the low detectability of species occurring at low abundance (Eberhard et al. 2009), combined with particular events at a well, such as small vertebrates falling down the well shaft.

\section{Factors affecting stygofauna occurrence}

The factors exerting most effect on the number of stygofauna animals and species in the groundwater around the well were depth to groundwater, DO in the top layer of groundwater, distance from the coast and geology, although none of these variables had strong explanatory power. While stygofauna have been found at depths of greater than 2,190 m from the surface in caves (Sendra and Reboleira 2012) and probably occur at depths greater than $100 \mathrm{~m}$ in the Pilbara, depth to groundwater is likely to be a major constraint on the complexity and abundance of stygofauna communities in the Pilbara. Numbers of animals collected were low where groundwater was more than $32 \mathrm{mbgl}$ (Figure 17) and a similar pattern was observed by Hancock and Boulton (2008). Hahn (2006) argued that it is hydrological connectivity between the surface and groundwater that controls the negative relationship between stygofauna occurrence and depth. The depth to which tree roots extend may be another important parameter because the roots appear to provide a food source for many species (Jasinska et al. 1996; see also Hancock and Boulton 2008). Groundwater recharge in the Pilbara, together with an influx of carbon, occurs after heavy monsoonal rainfall events (Dogramaci et al. 2012).

Using almost the same dataset as presented here, Reeves et al. (2007) examined the occurrence of stygobitic ostracods and found that less than $6 \%$ of the variance in ostracod occurrence was explained by topographic and water chemistry variables. While this was considered to be largely a result of low sampling efficiency resulting in ostracods not being collected from many sites where they actually occurred (see Eberhard et al. 2009), several other studies have also found that water chemistry has little effect on stygofauna occurrence (e.g. Hahn 2006; Dole-Olivier et al. 2009), despite the expectation that divalent cation and bicarbonate/ carbonate levels should be important for ostracods (Forester and Brouwers 1985; Gouramanis and De Deckker 2010) and perhaps other crustaceans (Glazier 1991). Little effect of water chemistry (other than salinity) was observed in the current analyses of the survey data.

Dissolved oxygen is usually considered to be a limiting factor for stygofauna because DO levels in groundwater can be very low (see Figure 5; Malard and Hervant 1999). Both abundance and richness of stygofauna would be expected to decline at low $\mathrm{DO}$, despite stygofauna being more tolerant of low DO than most animals (Malard and Hervant 1999; Mosslacher 2000). However, the relationship between stygofauna occurrence and DO in the survey data was not strong and groundwater with almost no DO sometimes contained multiple species (Figure 18). One possible reason for the lack of relationship is erroneous meter readings, especially when values of $0 \%$ were recorded. A second reason is that DO measured $1 \mathrm{~m}$ bswl probably did not reflect DO throughout the well profile in a significant proportion of wells (Figure $5 \mathrm{D}, \mathrm{G})$ and, therefore, did not adequately reflect $\mathrm{DO}$ in the surrounding aquifer (Figure 5A). Given the uncertainty about how reliably measurements reflected DO in the aquifer, and the small amount of variation in stygofauna occurrence explained by this variable, the impact of DO is not considered further other than to emphasise that it is a difficult variable to measure accurately during stygofauna investigations in deep groundwater. It is more amenable to study, and better understood, in shallow groundwater (Datry et al. 2005).

Perhaps the most surprising result of the survey was the apparently very minor role of geology in determining stygofauna sampling yields and, by inference, stygofauna occurrence 
in the surrounding aquifer (Figure 17). The most productive geology appeared to be mafic volcanics, which was unexpected and at variance with other studies that have suggested that porous and karstic aquifers (alluvium and calcrete in the Pilbara) are the more productive (Maurice and Bloomfield 2012). There are two reasons why the sampling results from the survey may be misleading in relation to geology. First, wells were assigned to the single geology in which they were located in Geological Survey maps. In reality, there was often a vertical succession of several geologies in a well, so that wells may have sampled a more prospective geology than maps indicated. Second, wells were usually deliberately located in places with relatively high transmissivity, which may have resulted in atypically high yields from some geologies.

In contrast to the overall sampling results of the survey, eight of the nine areas of high stygofauna richness identified by kriging were located in Quaternary alluvials. Mafic volcanics were present in part of just one area of high richness around the Sherlock River (Table 9). Similarly, calcrete was present in just part of just one area of high richness. Early inventory work in the Pilbara focused on calcrete (e.g. Humphreys 1999) and subsequent work in the Yilgarn has shown calcrete to be the most important habitat for stygofauna in that region (Humphreys 2001b; Cooper et al. 2002). Projects such as PASCALIS in Europe have shown karst and alluvium to be the main stygofauna geologies (Dole-Olivier et al. 2009) and, despite the survey results, it is likely that these are also the most productive geologies in most of the Pilbara.

\section{Stygofauna management in the Pilbara}

The principal aims of the survey were related to setting priorities for nature conservation, improving the understanding of factors affecting invertebrate stygofauna distribution and sampling yields (discussed above), and providing a framework for assessing stygofauna species and community significance in relation to environmental impact assessment. Given that little is known about the life histories of stygofaunal invertebrates in the Pilbara, environmental impact assessments have focused on the threat to species persistence rather than population impacts (EPA 2003, 2013). Consequently, the species of interest have been those with small ranges that may potentially be threatened by groundwater drawdown or, less frequently, groundwater pollution.

A recent European study by Michel et al. (2009) to compare methods of selecting reserves for the conservation of stygofauna showed that use of a complementarity algorithm led to more efficient protection of species than selecting reserved areas on the basis of high richness or endemism. However, the area of occupancy criterion chosen by Michel et al. (2009) required that $46 \%$ of cells known to contain stygofauna in Europe were conserved. Given that stygofauna occur over most of the Pilbara, such an extensive network of groundwater reserves for stygofauna is unlikely to be achievable, especially considering the spatial extent of groundwater drawdown associated with some large mines (Johnson and Wright 2001).

No areas for stygofauna conservation have been proposed here. However, mapping of sampling yields and fitting a species richness surface for stygofauna across the Pilbara (Figure 21) resulted in identification of nine areas of high stygofauna richness where some protection of stygofauna values may be warranted (Table 9, Figure 21). One of the smaller areas of richness identified by the survey, Ethel Gorge aquifer near Newman, has already been recognised as important for stygofauna and is listed as a Threatened Ecological Community by the Minister for the Environment. Listing reflects high conservation value of a community and the existence of a potential threat - in this case mine dewatering - to these values (English and Blyth 1999). The Ethel Gorge community was listed in 2001 prior to commencement of the survey because a large number of species of Chydaekata amphipods had been described in the area (Bradbury 2000). Subsequent genetic work suggested that a single species of Chydaekata occurred there (Finston et al. 2004, 2007) but results of the current survey and monitoring in the area (e.g. Subterranean Ecology $2012 b$ ) have shown that about 80 species occur in the vicinity of Ethel Gorge.

The largest of the nine areas of high richness identified in the survey extended from the lower Robe River valley, where well PSS016 on the coastal plain yielded 54 species of stygofauna from 11 samples (see Eberhard et al. 2009), southwards along the boundary of the Ashburton Lower and Middle sub-regions. The boundaries of this and other areas of high stygofauna richness identified by kriging are not exact and further work should be undertaken to define the spatial extent of this area of species richness before implementing any management actions to protect stygofauna. Nevertheless, there is sufficient information to identify this area as one of the most important areas for stygofauna in a region that is a global hotspot.

Another large area important for stygofauna is on the Sherlock River in the Port Hedland Coast Lower and Upper sub-regions. The western Fortescue Plain, east of Millstream-Chichester National Park, is another important area for stygofauna. The borefield to the west of Millstream was not 
identified here as important for stygofauna but its value as a water supply area, together with its proximity to Millstream, make it an area where stygofauna values may deserve more attention in water management planning than they are currently receiving (DoW 2010).

\section{Framework for environmental impact assessment}

The survey has provided a broad framework for assessing the environmental impacts of projects affecting groundwater in the Pilbara by facilitating taxonomic description of a large number of species, providing information about the typical size of species' ranges and about areas where abundant stygofauna occur, and refining the protocols for sampling (see Eberhard et al. 2005b, 2009).

Based on existing information, most species of copepod and oligochaete collected at mine sites or wellfields in the Pilbara have ranges extending into other sub-regions and are widespread at the likely scale of project impacts (see Table 7). However, most isopod and stygobitic ostracod species will be restricted to the sub-region in which a project occurs. Amphipod and syncarid species are also likely be restricted to single sub-regions (Finston et al. 2007; Guzik et al. 2008), although poorly developed taxonomy prevented the survey dataset from showing this clearly.

The average range of species collected from multiple sites but known from a single subregion was estimated to be $682 \mathrm{~km}^{2}$. This estimate makes several assumptions and is probably more realistic in flat landscapes near the coast than in the elevated and dissected landscapes of some headwaters. However, it suggests that persistence of about half of the stygofauna species known only from vicinity of a mine may potentially be threatened, or at least species populations may be substantially reduced, where mine dewatering drawdown extends over a radius of $10 \mathrm{~km}$ or more (e.g. Shepard et al. 2009). Large-scale water supply borefields may also affect stygofauna, although there is usually a requirement in such borefields for production rates to be sustainable, which prevents loss of large amounts of habitat (though see Kalf and Woolley 2005; Humphreys 2009).

The simple calculation above, and the conclusions about the proportion of species under threat, may have poor biological underpinning but it highlights the potential for deleterious conservation outcomes of groundwater abstraction (and perhaps reinjection) in a region that is globally important for stygofauna. The actual threat to stygofauna species can be determined only by two processes. First, species' ranges must be defined through adequate sampling or the effective use of surrogate information to define ranges. Second, the actual loss of habitat within the area of groundwater drawdown must be quantified. Shallow drawdowns will usually not affect persistence of stygofauna in an area unless there is stratification and the species are restricted to the upper layer of an aquifer.

Defining the range of a species requires accurate taxonomic delimitation of the species, whether or not it is formally described. There is increasing use of genetics to assist in delimiting species but it might be expected that the low dispersal capacity of stygofauna will often lead to significant genetic structuring within a species (e.g. Guzik et al. 2009, Asmyhr et al. 2013). Thus, if stygofauna species are to be recognised genetically, it is even more important than for surface species that large numbers of samples are collected to document the extent of intraspecific variation and detect interspecific divergences (Bergsten et al. 2012). Given the logistical difficulties associated with collecting large numbers of stygofauna species, morphology is likely to remain an important element of species delimitation even when genetics is used (see Carstens et al. 2013).

It is frequently impossible to determine from additional sampling whether the ranges of low abundance species, often collected as single animals or from single wells, extend beyond project impact areas (Guisan et al. 2006), especially when sampling is limited to whatever wells are available. Accordingly, the assessment guidance released by the EPA (2013) suggests that two types of surrogate information may be used to infer wider distribution of the low abundance species: namely, the distributions of other species; and the continuity of stygofauna habitat into undisturbed areas, as shown by contemporary gene flow within widespread species collected inside and outside the area of drawdown. In reality, the poor dispersal capacity of many stygofauna species means contemporary gene flow is unlikely to occur across the ranges of many species (e.g. Asmyhr et al. 2013). Maximising the available information on distributions of all stygofauna species in the local 'community' will probably provide more information about ranges of low abundance species than can be obtained from gene flow. Obtaining such distributional information requires sampling outside the area of groundwater drawdown and highlights the importance of the sampling program in impact assessment.

The sampling guidance released by the EPA (2007) recommended that 40 samples should be collected from the impact area of a development project (usually the area of groundwater drawdown) to characterise the potentially threatened fauna. The recommendation was based on, first, 12 samples being needed to collect nearly all the fauna from a single well (Eberhard et al. 2009) and, second, information from the current 
survey suggesting that half to a third of wells in any area yield substantially better than the surrounding wells (EPA 2007). This information was taken to indicate that perhaps only a third of wells were likely to reflect fully what was in the surrounding aquifer, with factors such as the exact position of the well, its construction, history of use and contamination contributing to variation in stygofauna yield. Thus, often 36 (rounded up to 40) samples are required to collect nearly all species if the impact area is in a single homogeneous aquifer type.

Subsequent sampling programs for impact assessment have shown that in most circumstances 40 samples collect only $50-80 \%$ of the fauna (e.g. Subterranean Ecology 2011; see also Figure 22B). The likely cause of this lower than predicted collection efficiency is that most projects do not cover only one type of aquifer. Instead, there may be several aquifers and fine-scale heterogeneity of habitat and water chemistry within these aquifers (Larned 2012), leading to impact areas containing multiple assemblages of stygofauna species, each of which reflects different habitat and water chemistry conditions (Hahn and Fuchs 2009; Maurice and Bloomfield 2012). Further studies of stygofauna ecology are likely to improve sampling efficiency and the capacity to predict stygofauna occurrence in different aquifer types. Until this occurs, significant sampling programs will continue to be required to assess the threat to stygofauna species from projects with large-scale impacts on groundwater (Karanovic, T. et al. 2013).

\section{ACKNOWLEDGMENTS}

We wish to thank staff of Biota Environmental Science for assistance with early sampling and BHP Billiton Iron Ore, Rio Tinto, Straits Resources, Department of Water and Main Roads WA for providing access to wells for sampling. In addition, we thank many pastoralists for providing information about wells on their properties that could be sampled. Department of Water purged bores to enable studies of water chemistry. Laboratory analyses of water were arranged by Jenny McGuire, ChemCentre.

Jane McRae guided the updating of taxonomic information and drew Figures 9 and 10 and Rowan Lymbery assisted with collating and checking the data and analyses. Ostracods were identified by Ivana Karanovic and Jessica Reeves; copepods and oligochaetes from the first 18 months of sampling were identified by Tomislav Karanovic and Adrian Pinder, respectively. Advice on some other identifications was provided by John Bradbury (amphipods), Buz Wilson and Niels Bruce (isopods), Chris Glasby (polychaetes), Mark Harvey (water mites) and Peter Serov (syncarids).
BHP Billiton Iron Ore provided an interpretation of Pilbara geology as the basis for examining stygofauna distribution in relation to geology and Nick Evelegh provided information on slotting of well casings. Comments by two anonymous reviewers improved the manuscript and were much appreciated.

\section{REFERENCES}

Abrams, K.M., Guzik, M.T., Cooper, S.J.B., Humphreys, W.F., King, R.A., Cho, J.L., and Austin, A.D. (2012). What lies beneath: molecular phylogenetics and ancestral state reconstruction of the ancient subterranean Australian Parabathynellidae (Syncarida, Crustacea). Molecular Phylogenetics and Evolution 64: 130-144.

Abrams, K.M., King, R.A., Guzik, M.T., Cooper, S.J.B. and Austin, A.D. (2013). Molecular phylogenetic, morphological and biogeographic evidence for a new genus of parabathynellid crustaceans (Syncarida: Bathynellacea) from groundwater in an ancient southern Australian landscape. Invertebrate Systematics 27: $146-172$.

Adams, M. and Humphreys, W.F. (1993). Patterns of genetic diversity within selected subterranean fauna of the Cape Range peninsula, Western Australia: systematic and biogeographic implications (pp. 145-164). In: Humphreys, W.F. (ed.), The biogeography of Cape Range, Western Australia. Records of the Western Australian Museum, Supplement 45. Western Australian Museum: Perth.

ALS (2012). Foxleigh Plains Project EIS: stygofauna report. ReportCQ212828-2011-001. ALS Water Sciences Queensland: Yeerongpilly, 24 pp.

APHA (1995). Standard methods for the examination of water and wastewater. American Public Health Association: Washington.

Asmyhr, M.G. and Cooper, S.J.B. (2012). Difficulties barcoding in the dark; the case of crustacean stygofauna from eastern Australia. Invertebrate Systematics 26: 583-591.

Asmyhr, M.G., Hose, G., Graham, P. and Stow, A.J. (2013). Fine-scale genetics of subterranean syncarids. Freshwater Biology 59: 1-11.

Barnett, J.C. and Commander, D.P. (1985). Hydrogeology of the Western Fortescue Valley, Pilbara region, Western Australia. Geological Survey Record 1986/8. Western Australia Geological Survey: Perth.

Bennelongia (2007). Report on subterranean fauna of the Duketon Gold Project area, north of Laverton. Report 2007/014. Bennelongia Pty Ltd: Jolimont. 23 pp.

Bennelongia (2008). Subterranean fauna sampling at Balmoral South Iron Ore Project and adjacent areas. Report 2008/42. Bennelongia Pty Ltd: Jolimont. 36 pp.

Bennelongia (2009a). Subterranean fauna assessment at Point Grey. Report 2009/71. Bennelongia Pty Ltd: Jolimont. $15 \mathrm{pp}$.

Bennelongia (2009b). Roy Hill remote borefield stygofauna assessment. Report 2009/068. Bennelongia Pty Ltd: Jolimont. 16 pp.

Bennelongia (2012a). Christmas Creek Life of Mine 
assessment, subterranean fauna assessment. Report 2012/121. Bennelongia Pty Ltd: Jolimont. 63 pp.

Bennelongia (2012b). Addendum: Pilbara Iron Ore Project, Blacksmith subterranean fauna surveys. Report 2012/137A. Bennelongia Pty Ltd: Jolimont. 39 pp.

Bennelongia (2012c). Subterranean fauna desktop study and field survey for the Sorby Hills Project. Report 2012/140. Bennelongia Pty Ltd: Jolimont. 24 pp.

Bergsten, J., Bilton, D.T., Fujisawa, T., Elliott, M., Monaghan, M.T., Balke, M., Hendrich, L., Geijer, J., Herrmann, J., Foster, G.N., Ribera, I., Nilsson, A.N., Barraclough, T.G. and Vogler, A.P. (2012). The effect of geographical scale of sampling on DNA barcoding. Systematic Biology 61: 851-869.

Bradbury, J.H. (2000). Western Australian stygobiont amphipods (Crustacea: Paramelitidae) from the Mt Newman and Millstream regions. Records of the Western Australian Museum, Supplement 60: 1-102.

Bruce, N.I. (2008). New species and a new genus of Cirolanidae (Isopoda: Cymothoida: Crustacea) from groundwater in calcretes in the Pilbara, northern Western Australia. Zootaxa 1823: 51-64.

Buick, R., Thornett, J.R., McNaughton, N.J., Smith, J.B., Barley, M.E. and Savage, M. (1995). Record of emergent continental crust $\sim 3.5$ billion years ago in the Pilbara Craton of Australia. Nature 375: 574-577.

Camacho, A.I. (1992). A classification of the aquatic and terrestrial subterranean environment and their associated fauna (pp. 58-103). In: Camacho, A.I. (ed.), The natural history of biospeleology. Museo Nacional de Ciencias Naturales: Madrid.

Camacho, A.I. and Hancock, P. (2011). Two new species of the genus Chilibathynella Noodt, 1963 and Onychobathynella bifurcata gen. et sp. nov (Crustacea: Syncarida: Parabathynellidae) from New South Wales, Australia. Journal of Natural History 46: 145-173.

Carstens, B.C., Pelletier, T.A., Reid, N.M. and Satler, J.D. (2013). How to fail at species delimitation. Molecular Ecology 22: 4369-4383.

Cho, J.-L. and Humphreys, W.F. (2010). Ten new species of the genus Brevisomabathynella Cho, Park and Ranga Reddy, 2006 (Malacostraca, Bathynellacea, Parabathynellidae) from Western Australia. Journal of Natural History 44: 993-1079.

Cho, J.-L., Park, J.-G. and Humphreys, W.F. (2005). A new genus and six species of the Parabathynellidae (Bathynellacea, Syncarida) from the Kimberley region, Western Australia. Journal of Natural History 39: 2225-2255.

Christiansen, K.A. (1961). Convergence and parallelism in cave Entomobryinae. Evolution 15: 288-301.

Colwell, R.K. (2006). EstimateS: statistical estimation of species richness and shared species from samples. http://purl.oclc.org/estimates.

Cook, B.D., Abrams, K.M., Marshall, J., Perna, C.N., Choy, S., Guzik, M.T. and Cooper, S.J.B. (2012). Species diversity and genetic differentiation of stygofauna (Syncarida: Bathynellacea) across an alluvial aquifer in north-eastern Australia. Australian Journal of Zoology 60: 152-158.

Cooper, S.J.B., Hinze, S., Leys, R., Watts, C.H.S. and Humphreys, W.F. (2002). Islands under the desert: molecular systematics and evolutionary origins of stygobitic water beetles (Coleoptera: Dytiscidae) from central Western Australia. Invertebrate Systematics 16: 589-598.

Crawley, M.J., (2007). The $R$ book. John Wiley \& Sons: Sussex.

Culver, D.C., Christman, M.C., Elliott, W.R., Hobbs, H.H. and Reddell, J.R. (2003). The North American obligate cave fauna: regional patterns. Biodiversity and Conservation 12: 441-468.

Danielopol, D.L., Griebler, C., Gunatilaka, A. and Notenboom, J. (2003). Present state and future prospects for groundwater ecosystems. Environmental Conservation 30: 104-130.

Datry, T., Malard, F. and Gibert, J. (2005). Does groundwater recharge stimulate biodiversity? (pp. 107-113). In: Gibert, J. (ed.), World subterranean biodiversity: Proceedings of an International Symposium, 8-10 December 2004, Villeurbanne France. Université Claude Bernard of Lyon 1, PASCALIS European Research Programme: Lyon.

Deharveng, L., Stoch, F., Gibert, J., Bedos, A., Galassi, D., Zagmajster, M., Brancelj, A., Camacho, A., Fiers, F., Martin, P., Giani, N., Magniez, G. and Marmonier, P. (2009). Groundwater biodiversity in Europe. Freshwater Biology 54: 709-726.

DMPR (2001). Western Australian iron ore industry. Department of Mineral and Petroleum Resources: Perth. 64 pp.

Dogramaci, S., Skrzypek, G., Dodson, W. and Grierson, P. (2012). Identifying recharge pattern using stable isotopes of rainfall in semi arid subtropical northwest Australia. Geophysical Research Abstracts 14: EGU20121234-1.

Dole-Olivier, M.-J., Malard, F., Martin, D., Lefébure, T. and Gibert, J. (2009). Relationships between environmental variables and groundwater biodiversity at the regional scale. Freshwater Biology 54: 797-813.

DoW (2010). Millstream water reserve: drinking water resource protection plan, West Pilbara water supply. Water Resource Protection Series WRP 116. Department of Water: Perth. 79 pp.

Eberhard, S.M., Halse, S.A. and Humphreys, W.F. (2005a). Stygofauna in the Pilbara region, north-west Western Australia: a review. Journal of the Royal Society of Western Australia 88: 167-176.

Eberhard, S.M., Halse, S.A., Scanlon, M.D., Cocking, J.S. and Barron, H.J. (2005b). Assessment and conservation of aquatic life in the subsurface of the Pilbara region, Western Australia (pp. 61-68). In: Gibert, J. (ed.), World subterranean biodiversity. Proceedings of an International Symposium, 8-10 December 2004, Villeurbanne, France. Université Claude Bernard of Lyon 1, PASCALIS European Research Programme: Lyon.

Eberhard, S., Leijs, R. and Adams, M.A. (2005c). Conservation of subterranean biodiversity in Western Australia: using molecular genetics to define spatial and temporal relationships in two species of cavedwelling Amphipoda. Subterranean Biology 3: 13-27.

Eberhard, S.M., Halse, S.A., Williams, M.R., Scanlon, 
M.D., Cocking, J.S. and Barron, H.J. (2009). Exploring the relationship between sampling efficiency and short range endemism for groundwater fauna in the Pilbara region, Western Australia. Freshwater Biology 54: 885-901.

English, V. and Blyth, J. (1999). Development and application of procedures to identify and conserve threatened ecological communities in the Southwest Botanical Province of Western Australia. Pacific Conservation Biology 5: 124-138.

Environment Australia (2008). Revision of the Interim Biogeographic Regionalisation for Australia (IBRA) and Development of Version 6.1. National Reserves System. Department of Environment, Water, Heritage and the Arts, Canberra. (online: http://www.environment/ gov.au/parks/nrs/science/bioregionframework/ ibra/index.html).

EPA (2003). Guidance for the assessment of environmental factors: consideration of subterranean fauna in groundwater and caves during environmental impact assessment in Western Australia. Guidance Statement 54. Environmental Protection Authority: Perth. 12 pp.

EPA (2007). Sampling methods and survey considerations for subterranean fauna in Western Australia (Technical Appendix to Guidance Statement No. 54). Guidance Statement 54A (Draft). Environmental Protection Authority: Perth. 32 pp.

EPA (2009). Balmoral South Iron Ore Project, Cape Preston, WA. Report and recommendations of the Environmental Protection Authority. Report 1340. Environmental Protection Authority: Perth. 34 pp. plus appendices.

EPA (2012) A review of subterranean fauna assessment in Western Australia. Environmental Protection Authority: Perth. 68 pp. plus appendices.

EPA (2013). Environmental assessment guideline for consideration of subterranean fauna in environmental impact assessment in Western Australia. Environmental Protection Authority: Perth. 20 pp.

Fellman, J.B., Dogramaci, S., Skrzypek, G., Dodson, W. and Grierson, P.F. (2011). Hydrologic control of dissolved organic matter biogeochemistry in pools of a subtropical dryland river. Water Resources Research 47: W06501. (13 pp.).

Finston, T.L., Bradbury, J.H., Johnson, M.S. and Knott, B. (2004). When morphology and molecular markers conflict: a case history of subterranean amphipods from the Pilbara, Western Australia. Animal Biodiversity and Conservation 27: 83-94.

Finston, T.L., Johnson, M.S., Eberhard, S.M., Cocking, J.S., McRae, J.M., Halse, S.A. and Knott, B. (2011). New genus and species of groundwater paramelitid amphipods from the Pilbara, Western Australia: a combined molecular and morphological approach. Records of the Western Australia Museum 26: 154-178.

Finston, T.L., Johnson, M.S., Humphreys, W.F., Eberhard, S.M. and Halse, S.A. (2007). Cryptic speciation in two widespread subterranean amphipod genera reflects historical drainage patterns in an ancient landscape. Molecular Ecology 16: 355-365.

Forester, R.M. and Brouwers, E.M. (1985). Hydrochemical parameters governing the occurrence of estuarine and marginal estuarine ostracodes: an example from south-central Alaska. Journal of Paleontology 59: 344-369.
Galassi, D.M.P., Huys, R. et al. (2009). Diversity, ecology and evolution of groundwater copepods. Freshwater Biology 54: 691-708.

Geological Survey of Western Australia (1990). Geology and mineral resources of Western Australia. Memoir 3, Western Australian Geological Survey: Perth. 827 pp.

GHD (2010). Stygofauna baseline survey: Murray drainage and water management plan and associated studies. GHD: Perth. 11 pp. + appendix.

Gibert, J. and Culver, D.C. (2009). Assessing and conserving groundwater biodiversity: synthesis and perspectives. Freshwater Biology 54: 930-941.

Gibert, J., Stanford, J.A., Dole-Olivier, M.-J. and Ward, J.V. (1994). Basic attributes of groundwater ecosystems and prospects for research (pp. 7-40). In: Gibert, J., Danielopol, D.L. and Stanford, J.A. (eds.), Groundwater Ecology. Academic Press: San Diego.

Glazier, D.S. (1991). The fauna of North American temperate cold springs: patterns and hypotheses. Freshwater Biology 26: 527-542.

Gleick, P.H. (1993). Water in crisis: A guide to the world's fresh water resources. Oxford University Press: Oxford.

Gouramanis, C. and De Deckker, P. (2010). Alkalinity control on the partition coefficients in lacustrine ostracodes from Australia. Geology 38: 359-362.

Guisan, A., Broennimann, O., Engler, R., Vust, M., Yoccoz, N.G., Lehmann, A. and Zimmermann, N.E. (2006). Using niche-based models to improve the sampling of rare species. Conservation Biology 20: 501-511.

Guzik, M.T., Abrams, K.M., Cooper, S.J.B., Humphreys, W.F., Cho, J.-L. and Austin, A.D. (2008). Phylogeography of the ancient Parabathynellidae (Crustacea: Bathynellacea) from the Yilgarn region of Western Australia. Invertebrate Systematics 22: 205-216.

Guzik, M.T., Cooper, S.J.B., Humphreys, W.F. and Austin, A.D. (2009). Fine-scale comparative phylogeography of a sympatric sister species triplet of subterranean diving beetles from a single calcrete aquifer in Western Australia. Molecular Ecology 18: 3683-3698.

Guzik, M.T., Austin, A.D., Cooper, S.J.B., Harvey, M.S., Humphreys, W.F., Bradford, T., Eberhard, S.M., King, R.A., Leys, R., Muirhead, K.A. and Tomlinson, M. (2010). Is the Australian subterranean fauna uniquely diverse? Invertebrate Systematics 24: 407-418.

Hahn, H.J. (2006). The GW-Fauna-Index: a first approach to a quantitative ecological assessment of groundwater habitats. Limnologia 36: 119-137.

Hahn, H.J. and Fuchs, A. (2009). Distribution patterns of groundwater communities across aquifer types in south-western Germany. Freshwater Biology 54: 848-860.

Hancock, P. and Bennison, G. (2005). Ord Stage 2 M2 area - stygofauna survey. Contract 13DIR0104 (WA Department of Industry and Resources). Ecowise Environmental: Brisbane. 36 pp.

Hancock, P.J. and Boulton, A.J. (2008). Stygofauna biodiversity and endemism in four alluvial aquifers in eastern Australia. Invertebrate Systematics 22: 117-126.

Hancock, P.J. and Boulton, A.J. (2009). Sampling groundwater fauna: efficiency of rapid assessment methods tested in bores in eastern Australia. Freshwater Biology 54: 902-917. 
Holmes, A.J., Tujula, N.A., Holley, M., Contos, A., James, J.M., Rogers, P. and Gillings, M.R. (2001). Phylogenetic structure of unusual aquatic microbial formations in Nullarbor caves, Australia. Environmental Microbiology 3: 256-264

Holthuis, L.B. (1960). Two species of atyid shrimps from subterranean waters of N.W. Australia (Decapoda Natantia). Crustaceana 1: 47-57.

Hose, G.C. and Lategan, M.J. (2012). Sampling strategies for biological assessment of groundwater ecosystems. Technical Report 21. CRC for Contamination Assessment and Remediation of the Environment: Adelaide. 32 pp.

Humphreys, W.F. (1999). Relict stygofaunas living in sea salt, karst and calcrete habitats in arid northwestern Australia contain many ancient lineages (pp. 219-227). In: Ponder, W. and Lunney, D. (eds), The Other 99\%: The Conservation and Biodiversity of Invertebrates. Royal Zoological Society of New South Wales: Sydney.

Humphreys, W.F. (2000). The hypogean fauna of the Cape Range peninsula and Barrow Island, northwestern Australia (pp. 581-601). In: Wilkens, H., Culver, D.C. and Humphreys, W.F. (eds.), Subterranean Ecosystems. Ecosystems of the World. Elsevier: Amsterdam.

Humphreys, W. (2001a). Milyeringa veritas (Eleotridae), a remarkably versatile cave fish from the arid tropics of northwestern Australia. Environmental Biology of Fishes 62: 297-313.

Humphreys, W.F. (2001b). Groundwater calcrete aquifers in the Australian arid zone: the context to an unfolding plethora of stygal biodiversity. Records of the Western Australian Museum, Supplement 64: 63-83.

Humphreys, W.F. (2008). Rising from Down Under: developments in subterranean biodiversity in Australia from a groundwater fauna perspective. Invertebrate Systematics 22: 85-101.

Humphreys, W. (2009). Hydrogeology and groundwater ecology: Does each inform the other? Hydrogeology Journal 17: 5-21.

Humphreys, W.F., Watts, C.H.S., Cooper, S.J.B. and Leijs, R. (2009). Groundwater estuaries of salt lakes: buried pools of endemic biodiversity on the western plateau, Australia. Hydrobiologia 626: 79-95.

Jasinska, E.J., Knott, B. and McComb, A.J. (1996). Root mats in groundwater: a fauna-rich habitat. Journal of the North American Benthological Society 15: 508-519.

Johnson, D.P. (2004). The geology of Australia. Cambridge University Press: London.

Johnson, S.L. and Wright, A.H. (2001). Central Pilbara groundwater study, Western Australia. HG8, Water and Rivers Commission: Perth.

Kalf, F.P. and Woolley, D. (2005). Applicability and methodology of determining sustainable yield in groundwater systems. Hydrogeology Journal 13: 295312

Karanovic, I. (2003). A new genus of Candoninae (Crustacea, Ostracoda, Candonidae) from the subterranean waters of southwestern Australia. Records of the Western Australian Museum 32: 315-332.

Karanovic, I. (2005). A new Candoninae genus (Crustacea: Ostracoda) from subterranean waters of Queensland, with a cladistic analysis of the tribe Candonopsini.
Memoirs of the Queensland Museum 50: 303-319.

Karanovic, I. (2006). On the genus Gomphodella (Crustacea: Ostracoda: Limnocytheridae) with descriptions of three new species from Australia and redescription of the type species. Species Diversity 11: 99-135.

Karanovic, I. (2007). Candoninae (Ostracoda) from the Pilbara region in Western Australia. Crustaceana Monographs 7: 1-432.

Karanovic, I. (2009). Four new species of Gomphodella De Deckker with a phylogenetic analysis and a key to the living representatives of the subfamily Timiriaseviinae (Ostracoda). Crustaceana 82: 1133-1176.

Karanovic, I. and McKay, K. (2010). Two new species of Leicacandona Karanovic (Ostracoda, Candoninae) from the Great Sandy Desert, Australia. Journal of Natural History 44: 2715-2736.

Karanovic, I., and Marmonier, P. (2002). On the genus Candonopsis (Crustacea: Ostracoda: Candoninae) in Australia, with a key to the world recent species. Annales de Limnologie 38: 199-240.

Karanovic, T. (2006). Subterranean copepods (Crustacea, Copepoda) from the Pilbara region in Western Australia. Records of the Western Australian Museum Supplement 70: 1-239.

Karanovic, T. (2010). First record of the harpacticoid genus Nitocrellopsis (Copepoda, Ameiridae) in Australia, with descriptions of three new species. Annales de Limnologie 46: 249-280.

Karanovic, T. and Cooper, S.J.B. (2012). Explosive radiation of the genus Schizopera on a small subterranean island in Western Australia (Copepoda: Harpacticoida): unravelling the cases of cryptic speciation, size differentiation and multiple invasions. Invertebrate Systematics 26: 115-192.

Karanovic, T. and Eberhard, S.M. (2009). Second representative of the order Misophrioida (Crustacea, Copepoda) from Australia challenges the hypothesis of the Tethyan origin of some anchialine faunas. Zootaxa 2059: 51-68.

Karanovic, T., Eberhard, S.M., Perina, G. and Callan, S. (2013). Two new subterranean ameirids (Crustacea: Copepoda: Harpacticoida) expose weaknesses in the conservation of short-range endemics threatened by mining developments in Western Australia. Invertebrate Systematics 27: 540-566.

Karanovic, T. and Krajicek, M. (2012). First molecular data on the Western Australian Diacyclops (Copepoda, Cyclopoida) confirm morpho-species but question size differentiation and monophyly of the Alticolagroup. Crustaceana 85: 1549-1569.

Keable, S.J. and Wilson, G.D.F. (2006). New species of Pygolabis Wilson, 2003 (Isopoda, Tainisopidae, Crustacea) from Western Australia. Zootaxa 1116: 1-27.

King, R.A., Bradford, T., Austin, A.D., Humphreys, W.F. and Cooper, S.J.B. (2012a). Divergent molecular lineages and not-so-cryptic species: the first descriptions of stygobitic chiltoniid amphipods (Talitroidea: Chiltoniidae) from Western Australia. Journal of Crustacean Biology 32: 465-488.

King, R.A, Fagan-Jefferies, E., Cooper, S.J.B., Finston, T. and Humphreys, W.F. (2012b). Resolving the 
systematics of stygobitic Amphipoda using morphology and genetic analyses - Melitidae of central Western Australia. In Abstract book, 21 ${ }^{\text {st }}$ International Conference on Subterranean Biology, September 2012, Koice, Slovalia. Pavol Josef Safarik University: Kosice. pp. 58.

Knott, B. and Halse, S.A. (1999). Pilbarophreatoicus platyarthricus n. gen., n. sp. (Isopoda: Phreatoicidae: Amphisopodidae) from the Pilbara region of Western Australia. Records of the Australian Museum 51: 33-42.

Larned, S.T. (2012). Phreatic groundwater ecosystems: research frontiers for freshwater ecology. Freshwater Biology 57: 885-906.

Larson, H.L., Foster, R., Humphreys, W.F. and Stevens, M.I. (2013). A new species of the blind cave gudgeon Milyeringa (Gobioidei, Eleotridae, Butinae) from Barrow Island, Western Australia, with a redescription of M. veritas Whitley. Zootaxa 3616: 135-150.

Leijs, R., Bloechl, A. and Koenemann, S. (2011). Bogidiella veneris, a new species of subterranean Amphipoda (Bogidiellidae) from Australia, with remarks on the systematics and biogeography. Journal of Crustacean Biology 31: 566-575.

Leys, R., Roudnew, B. and Watts, C.H.S. (2010). Paroster extraordinarius sp. nov., a new groundwater diving beetle from the Flinders Ranges, with notes on other diving beetles from gravels in South Australia (Coleoptera: Dytiscidae). Australian Journal of Entomology 49: 66-72.

McKenzie, N.L., van Leeuwen, S. and Pinder, A.M. (2009). Introduction to the Pilbara Biodiversity Survey, 2002-2007. Records of the Western Australian Museum, Supplement 78: 3-89.

Malard, F. and Hervant, F. (1999). Oxygen supply and the adaptations of animals in groundwater. Freshwater Biology 41: 1-30.

Maurice, L. and Bloomfield, J. (2012). Stygobitic invertebrates in groundwater - a review from a hydrogeological perspective. Freshwater Reviews 5: 51-71.

Michel, G., Malard, F., Deharveng, L., Di Lorenzo, T., Sket, B. and De Broyer, C. (2009). Reserve selection for conserving groundwater biodiversity. Freshwater Biology 54: 861-876.

Mosslacher, F. (2000). Sensitivity of groundwater and surface water crustaceans to chemical pollutants and hypoxia: implications for pollution management. Archiv für Hydrobiologie 149: 51-66.

Moulds, T.A. (2007). Subterranean fauna of the Eneabba, Jurien and South Hill River (Nambung) karst areas, Western Australia. Unpublished report prepared for the Department of Environment and Conservation, Western Australia - Midwest Region. 27 pp.

Moulds, T. and Bannink, P. (2012). Preliminary notes on the cavernicolous arthropod fauna of Judbarra/ Gregory karst area, northern Australia. Helictite 41: 75-85.

Murphy, N.P., Adams, M. and Austin, A.D. (2009). Independent colonization and extensive cryptic speciation of freshwater amphipods in the isolated groundwater springs of Australia's Great Artesian Basin. Molecular Ecology 18: 109-122.
Page, T.J., Humphreys, W.F. and Hughes, J.M. (2008). Shrimps down under: evolutionary relationships of subterranean crustaceans from Western Australia (Decapoda: Atyidae: Stygiocaris). PLoS ONE 3(2), e1618. doi:10.1371/journal.pone.0001618.

Payne, J.L. and Finnegan, S. (2007) The effect of geographic range on extinction risk during background and mass extinction. Proceedings of the National Academy of Sciences 104: 10506-10511.

Pinder, A.M., Halse, S.A., Shiel, R.J. and McRae, J.M. (2010). An arid zone awash with diversity: patterns in the distribution of aquatic invertebrates in the Pilbara region of Western Australia. Records of the Western Australia Museum, Supplement 78: 205-246.

Pipan, T. And Culver, D.C. (2012). Convergence and divergence in the subterranean realm: a reassessment. Biological Journal of the Linnean Society 107: 1-14.

Ponder, W.F. and Colgan, D.J. (2002). What makes a narrow-range taxon? Insights from Australian freshwater snails. Invertebrate Systematics 16: 571-582.

Poore, G.C.B. and Humphreys, W.F. (1992). First record of Thermosbaenacea (Crustacea) from the Southern Hemisphere: a new species from a cave in tropical Western Australia. Invertebrate Taxonomy 6: 719-725.

Poore, G.C.B. and Humphreys, W.F. (1998). First record of Spelaeogriphacea from Australasia: a new genus and species from an aquifer in the arid Pilbara of Western Australia. Crustaceana 71: 721-742.

Reeves, J.M., De Deckker, P. and Halse, S.A. (2007) Groundwater ostracods from the arid Pilbara region of northwestern Australia: distribution and water chemistry. Hydrobiologia 585: 99-118.

Schmidt, S., Hahn, H., Hatton, T. and Humphreys, W. (2007). Do faunal assemblages reflect the exchange intensity in groundwater zones? Hydrobiologia 583: 1-19.

Schon, I., Martens, K. and Halse, S. (2010). Genetic diversity in Australian ancient asexual Vestalenula (Ostracoda, Darwinulidae) - little variability downunder. Hydrobiologia 641: 59-70.

Sendra, A. and Reboleira, A.S.P.S. (2012). The world's deepest subterranean community - Krubera-Voronja cave (Western Caucasus). International Journal of Speleology 41: 221-230.

Sheppard, G., Gallardo, A., Hall, J. and Strizek, M. (2009). Managing the cumulative groundwater impacts of multiple iron ore projects at Cape Preston (or ... one plus one plus one plus one does not equal four). Mining Technology 118: 152-161.

Sket, B., Paragamian, K. and Tontelj, P. (2004). A census of the obligate subterranean fauna of the Balkan Peninsula (pp. 309-322). In: Griffith, H.I. (ed.), Balkan biodiversity. Kluwer Academic: Dordrecht.

Sket, B. (2008). Can we agree on an ecological classification of subterranean animals? Journal of Natural History 42: 1549-1563.

Subterranean Ecology (2011). Solomon Project: Kings deposits subterranean fauna survey and assessment. Report 2010/20, Subterranean Ecology Pty Ltd: Stirling. 91 pp. plus appendices.

Subterranean Ecology (2012a). Elimatta Project: stygofauna survey. Report 2011/24, Subterranean Ecology Pty Ltd: Stirling. 29 pp. 
Subterranean Ecology (2012b). Orebody 23/25 and Jimblebar discharge: stygofauna monitoring annual report 2012. Report 2012/11. Subterranean Ecology Pty Ltd: Stirling. 66 pp.

Susac, R.A.J., Anderson, J. and Moulds, T.A. (2010). Comparisons of subterranean biodiversity from the west Kimberley karst, Australia (pp. 92-93). In: Moškri冈, A. and Trontelj, P. (eds), Abstracts book, 20th International Conference on Subterranean Biology. Slovenian Ministry of the Environment and Spatial Planning and Slovenian Research Agency-ARRS: Postojna.

Tang, D., Barron, H. and Goater, S.E. (2008). A new genus and species of the Ridgewayiidae (Copepoda: Calanoida) from subterranean waters of northwestern Australia. Journal of Crustacean Biology 28: 551-563.

Tang, D. and Knott, B. (2009). Freshwater cyclopoids and harpacticoids (Crustacea: Copepoda) from the Gnangara Mound region of Western Australia. Zootaxa 2029: 1-70.

Thurgate, M.E., Gough, J.S., Clarke, A.K., Serov, P. and Spate, A. (2001a). Stygofauna diversity and distribution in eastern Australian cave and karst areas. Records of the Western Australian Museum, Supplement 64: 49-62.

Thurgate, M.E., Gough, J.S., Spate, A. and Eberhard, S. (2001b). Subterranean biodiversity in New South Wales: from rags to riches. Records of the Western Australia Museum, Supplement 64: 37-47.

Watts, C.H.S., Hancock, P.J. and Leys, R. (2007). A stygobitic Carabhydrus Watts (Dytiscidae, Coleoptera) from the Hunter Valley in New South Wales, Australia. Australian Journal of Entomology 46: 56-59.

Watts, C.H.S., Hancock, P.J. and Leys, R. (2008). Paroster peelensis sp. nov.: a new stygobitic water beetle from alluvial gravels in northern New South Wales (Coleoptera: Dytiscidae). Australian Journal of Entomology 47: 227-231.

Watts, C.H.S. and Humphreys, W.F. (2006). Twenty-six new Dytiscidae (Coleoptera) of the genera Limbodessus Guignot and Nirripirti Watts and Humphreys, from underground waters in Australia. Transactions of the Royal Society of South Australia 130: 123-185.

Watts, C.H.S. and Humphreys, W.F. (2009). Fourteen new Dytiscidae (Coleoptera) of the genera Limbodessus Guignot, Paroster Sharp, and Exocelina Broun from underground waters in Australia. Transactions of the Royal Society of South Australia 133: 62-107.

Watts, C.H.S. and McRae, J.M. (2013). Limbodessus bennetti sp. nov.: first stygobitic Dytiscidae from the Pilbara region of Western Australia. Records of the Western Australian Museum 28(2): 141-143.

Whitely, P.G. (1945). New sharks and fishes from Western Australia. Part 2. Australian Zoologist 11: 1-45.

Wilson, G.D.F. and Ponder, W.F. (1992). Extraordinary new subterranean Isopods (Peracardia: Crustacea) from the Kimberley region, Western Australia. Records of the Australian Museum 44: 279-298.

\section{APPENDIX 1 [ELECTRONIC]}

Locations of wells sampled.

\section{APPENDIX 2 [ELECTRONIC]}

Water chemistry at each well.

\section{APPENDIX 3 [ELECTRONIC]}

List of stygofauna species collected with occurrence at each well.

\section{See CD inside the back cover or visit}

http://www.museum.wa.gov.au/research/records-supplements/ 